\title{
The Transition of a Typical Frontier
}

\author{
with illustrations from \\ The Life of Henry Hastings Sibley, \\ Fur Trader, First Delegate in Congress from Minnesota Territory, \\ and First Governor of the State of Minnesota
}

\section{A THESIS}

SUBMTTTED IN PARTIAL BULFILLMENT OF THE REQUIREMENTS

FOR THE DEGREE OF DOCTOR OF PHILOSOPHY

\section{WILSON PORTER SHORTRIDGE, M.A.}

\author{
IN THE GRADUATE SCHOOL OF THE \\ UNIVERSITY OF MINNESOTA
}




\title{
The Transition of a Typical Frontier
}

\author{
with illustrations from
}

The Life of Henry Hastings Sibley,

Fur Trader, First Delegate in Congress from Minnesota Territory, and First Governor of the State of Minnesota

\section{A THESIS}

SUBMITTED IN PARTIAL FULFILLMENT OF THE REQUIREMENTS

FOR THE DEGREE OF DOCTQR , OF PHILOSOPHY
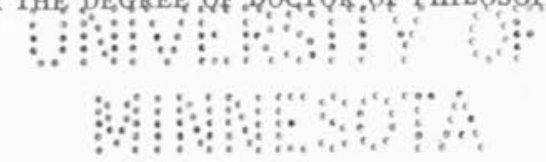

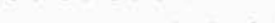

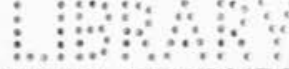

WILSON PORTER SHORTRIDGE, M.A.

IN THE GRADUATE SCHOOL OF THE

UNIVERSITY OF MINNESOTA 
The Cullegtate Freas

GEORGE BANTA PUBLISHING COMPANY

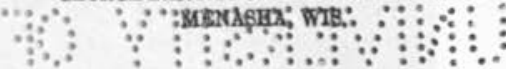

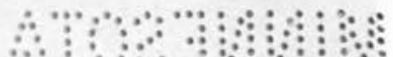

$\therefore: \vdots, \because, \ldots, \because: \because:: \vdots \because$

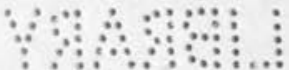




\section{PREFACE}

This account of frontier transition is a study in the history of the West. If the West be thought of as a period rather than a place, then the study of a limited area which passed through the successive stages in the evolution of society on the frontier should be typical of what was repeated over and over again in the conquest and settlement of the continent. And, in the same way, if a study be made of an individual who lived through and participated in, or at least witnessed, the various steps vivid illustrations of the significant features of the westward movement may be found. In the second and third quarters of the nineteenth century that part of the upper Mississippi Valley which became Minnesota passed through the evolution of society from frontier to statehood, and the most prominent man in that region during the period was Henry Hastings Sibley, fur trader, first delegate in Congress from Minnesota Territory, and first governor of the State of Minnesota. This region and this individual have been selected, therefore, as types in this study of frontier transition.

The Sibley family furnishes a good illustration of the migration of the New England element of our population. The story

of this family takes its beginning in Old England, going back through the centuries almost, if not quite, to the time of the Norman Conquest. After picking up the threads of the story in England, certain members of the family will be followed across the Atlantic to the shores of New England, to what may be called the first American West. From New England the story will follow along the trail that leads to the first real American West, the region beyond the Alleghanies, first to Marietta and then to Detroit. In particular, this study will follow the fortunes of a younger son of the Sibley family in Detroit from his boyhood home to the Indian country of the upper Mississippi, where he lived through the successive 
changes from fur traders' frontier, through territorial days and into statehood. Three different times did representatives of this family migrate to a newer American West and live through this evolution of society. Constant attention has been given in this study to the phases of development that were typical of what has taken place in different parts of the country. The problems confronting the settlers in new areas were more or less similar, and this makes possible a type study of this nature. The story of this family also illustrates the fact that, as a general rule, each area was settled by people who were born in an adjoining region, or an older region, to the East. Sometimes certain individuals or certain classes drifted along with the frontier, but the more ambitious pioneers went farther west to get a start in life, settled down, and waited for the later waves of civilization to overtake them. It is a very significant fact in the history of the West that one could go as a young man into a new region, as Sibley went into the upper Mississippi country, and live to see that region a settled area with a civilization and conveniences equal to those found in the older communities in the East, and it is still more striking that this change should have taken place in time for that same individual to be able to enjoy for many years the conveniences of city life. By centering our attention on a given region during the lifetime of a single individual it is possible, therefore, to see the various changes that came in rapid succession in the history of the West.

The material upon which this study is based is indicated in the chapter on bibliography, but special mention might be made of the Sibley and Ramsey Papers. This material consists of several thousand papers, chiefly correspondence, of the two men most prominent in the making of Minnesota. Sibley carefully preserved letters and papers from the time he first came to Minnesota and, after his death, most of these were turned over to the Minnesota Historical Society. They contain much valuable material on the early history of Minnesota and cover the period from 1830 to 1890 . Since most of the correspondence 
mentioned in this study has been taken from the Sibley Papers it will be assumed, unless direct reference is given to the contrary, that the material in question is found in them. The Ramsey Papers, while not so extensive as the Sibley Papers, also contain much valuable material, particularly on Indian relations and early politics. Many of Sibley's letters are found here. The Minnesota Historical Society has a very valuable collection of newspapers published in Minnesota, dating from the very year that the territory was organized, and these files have been used in gathering material for this study.

Since this work has grown out of the author's study of the history of the West, several friends have aided either directly or indirectly in its preparation. The author's interest in the history of the West was first aroused in the classes and seminary of Professor Frederick J. Turner, at the University of Wisconsin in 1909 and 1910, and the work was later continued under Professor Solon J. Buck, at the University of Minnesota. Especially the author desires to acknowledge his deep indebtedness to Professor Buck for the encouragement and valuable assistance which he freely gave at all stages in the preparation and publication of this work. Every chapter in the original dissertation was gone over with Professor Buck, and his criticisms and suggestions helped the author to avoid many errors which otherwise would have appeared. It is not assumed, however, that even so mistakes did not creep in, and for all of these the author assumes full responsibility. Acknowledgments are also due and are gladly given to the several assistants in the Minnesota Historical Society, and especially to those in the manuscript department, for the help which they gave. Entire justice in making acknowledgments would not be done without a statement as to the interest manifested in the author's work by Professor August C. Krey, of the University of Minnesota, whose encouragement helped the author over many hard places.

University of Louisville

W. P. S.

January 21, 1922 


\section{CONTENTS}

Chapter I. A Type of the New England Element in the West..... I

Chapter 2. The Fur Traders' Frontier................... II

$\begin{array}{lll}\text { Chapter } & 3 . \\ \text { The Pioneer Days on the Upper Mississippi.......... } 27\end{array}$

Chapter 4 . The Making of a New Territory................. 35

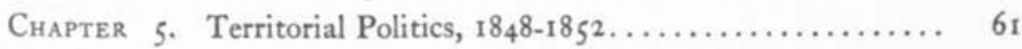

Chapter 6. The Needs of a New Territory .................... 79

Chapter 7. The Indian Problem on the Frontier............. $9^{1}$

Chapter 8. Territorial Growth and the Organization of a State.... 120

Chapter 9. The Advent of the Railroad to Minnesota........... ${ }^{1} 3^{2}$

Chapter 10. The Last Stand of the Sioux Indians in Minnesota..... ${ }_{146}$

Chapter it. Pioneer Dreams Come True................... 165

Chapter 12. Bibliography............................. 174

\section{LIST OF MAPS}

Fur trading posts along the upper Mississippi, $1826 \ldots \ldots \ldots \ldots \ldots . \ldots \mathbf{I}_{4}$

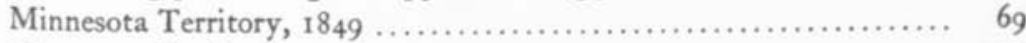

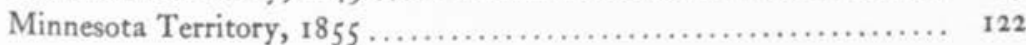




\section{CHAPTER I}

\section{A TYPE OF THE NEW ENGLAND ELEMENT IN THE WEST}

Soon after the close of the American Revolution New Englanders began the great migration across the Appalachian Mountains. Even before this time the expanding population had advanced northward into New York and Pennsylvania. ${ }^{1}$ All of these migrations were brought about from much the same causes and were carried out in much the same way. At about the time that the members of the Convention of 1787 met and drew up the Constitution of the United States "in order to form a more perfect union" the foundation was being laid for a new state west of Pennsylvania, and this beginning was made by New Englanders. Each generation furnished pioneers for the settlement of another area farther west. From New York and Pennsylvania, as well as from New England itself, the New England element passed into Ohio, northern Indiana and Illinois, where it met the stream of population coming across the Ohio river from the southward. In these states institutions were modified but not controlled by the New England influence. In the next tier of states settled and admitted in to the Union, however, the local institutions were suggestive of New England. Michigan, Wisconsin, Iowa, and Minnesota were settled quite largely by New Englanders or by their descendants who had lived for a time at some settlement along the path of the westward march of population. The New England influence was strong enough in these states to control permanently the form of local institutions in spite of migration from other states and an unusually large number of foreign immigrants. It is possible, therefore, to select a

${ }^{1}$ Lois Kimball Mathews, The Expansion of Neto England, Chapter VI. 
typical New England family and follow its members into the West, thus illustrating how the migration took place and how institutions were transplanted.

Henry Hastings Sibley, a pioneer on the Minnesota frontier, came from pure New England stock and may therefore be taken as a type of the New England element. The family history, on his father's side, goes back without a break in the story to the great Puritan emigration to Massachusetts, and careful genealogists have claimed to be able to trace it back to the time of the Norman Conquest. The name appears, with several different spellings, in many local records in England. In the time of Edward I the Sibleys were listed as owners of land in Kent, Oxford, and Suffolk. In the sixteenth century one John Sibley was mayor of St. Albans, and it is probably from him that the American Sibleys were descended. In the long struggle between king and parliament the Sibleys often divided, as many old English families did, some members favoring one side and other members the other. The second quarter of the seventeenth century was the time of the great Puritan emigration to America, and it was this movement that brought the Sibleys to the new world. The first individuals of the family to come to America seem to have been two brothers, John and Richard, who came to Salem, possibly in 1629 , certainly before $1634 \cdot^{2}$

John Sibley, the ancestor of the branch of the family under consideration, took the freeman's oath on September 3, I634, and his name is to be found in the list of the members of the First Church of Salem. He was selectman at Salem in 1636 and held a similar office at Manchester in 1645 and again in 1658. He died in 166r. Joseph Sibley, the third son of John Sibley, was born in 1655 . He was a landowner and husbandman and engaged to some extent in fishing, but this is about all that is known about him. He bought land in Sutton, Massachusetts, and three of his six sons were among the 2 William A. Benedict and Hiram A. Tracy, History of the Town of Sutton, 718 . Also West,
The Ancestry, Life and Times of Henry Hastings Sibley, $1-17$. 
founders of this new town of Sutton. His other three sons later settled in the same place, and already the westward migration of the family had begun.

The settlement of Sutton was typical of the New England method of founding new towns. By the beginning of Queen Anne's War most of eastern Massachusetts had been settled and much land had been taken up in the Connecticut valley, while between these places there were only a few isolated areas of settlement. Because the land was not so good in this section and also because it was more exposed to Indians raids it had been passed over by the earlier settlers. People began to come into the region after the close of hostilities in 1713 and it was here that the new town of Sutton was founded. ${ }^{3}$ The land was first purchased from some Nipmug Indians in 1704 by the "Proprietors of Sutton" and was described as "a tract of waste lands eight miles square, lying between the Towns of Mendon, Worcester, New Oxford, Sherburne and Marlborough, embracing within its limits an Indian reservation of four miles square called Hassanimisco." The proprietors then applied to the Governor and General Assembly for the confirmation of the grant and for permission to establish the town. The petition was granted in 1704 on condition that thirty families and a minister should be settled within seven years after the close of the war. The war closed in 1713 , but it was not until 1716 that the first families settled in the town. By the end of 1717 the thirty families were there and among them were Joseph, Jonathan, and John Sibley, sons of the above mentioned Joseph Sibley. The second Joseph Sibley (born I684) was the Sutton ancestor of Henry Hastings Sibley. For three generations this branch of the family was identified with the history of Sutton, taking at different times a more or less important part in the political and social life of the town. - This second Joseph Sibley had a son named Jonathan (born 1718) who was the father of Reuben Sibley. The latter was the father of

\footnotetext{
${ }^{3}$ Lois Kimball Mathews, The Expansion of New England, 78-79. Also map, 70.
} 
Solomon Sibley, the representative of the family who went to Marietta and finally to Detroit. ${ }^{4}$

Solomon Sibley was born in Sutton, Massachusetts, October 5, 1769. He received a good elementary education and studied law under William Hastings, of Boston. Feeling the influence of the movement of population to the region beyond the mountains he set his face westward in 1795 , went to Marietta, and henceforth identified himself with the Old Northwest. After a year at Marietta he moved to Cincinnati. While practicing law here, he and Judge Burnet made a trip to attend the summer session of court at Detroit, swimming streams and sleeping on the ground, their provisions being carried on a pack horse. Sibley was favorably impressed with Detroit and decided to make it his future home. He was the first settler to go to Detroit after the evacuation of that post by the British in 1796 as provided in Jay's Treaty..$^{5}$ He engaged in such practice of the law as existed in a frontier community, and in 1799 was elected as the first member to represent Wayne county in the first territorial legislature of the Northwest Territory which met at Chillicothe. In 1802 he introduced into the territorial legislature the bill to incorporate Detroit. In 1806 he was mayor of Detroit by appointment of Governor Hull and in 1815 , when Detroit regained control of its local affairs, he was one of the five trustees and was chosen as the first president of the town board. In 1817 he was a commissioner with General Lewis Cass to treat with the Ottawa, Chippewa, and Pottawatomie Indians for the cession of lands in the present State of Michigan. ${ }^{6}$ From 1820 to 1823 he was the delegate to Congress from the Territory of Michigan, and in 1821 he became a trustee of the University of Michigan, a pioneer "State" University. From 1824 to 1837 , the close of the territorial period, he was chief justice of the supreme

'Benedict and Tracy, History of Sutton, 9-12; 15; 18.

Michigan Pioneer and Historical Collections, 6:488. Also Mathews, The Expansion of
England, 230. Nete England, 230 .

This cession embraced lands bounded on the north by Grand river, on the west by Lake Michigan, and on the south by the present state line, except a small parcel of land in the southwest corner of the State. Michigan Pioneer and Historical Collections, $30: 178 ; 18: 693 ; 26: 284$. 
court of Michigan Territory. ${ }^{7}$ Such, in brief, was the political life of the father of Henry Hastings Sibley. This sketch shows that he was a leader in his community and played an important part in the making of the territory and State of Michigan as was the case with his son in a newer West, the region which became Minnesota. There are some interesting parallels in the lives of father and son in these two frontier regions. Both served in territorial legislatures, both were delegate in Congress from a territory, and both were prominent in the building of a State University.

In 1802 Solomon Sibley married Sarah Whipple Sproat at Marietta and took his bride by way of the Ohio river to Pittsburg, thence to Lake Erie, and then by boat to Detroit. Sarah Whipple Sproat was a very remarkable woman whose family history was no less honorable and distinguished than that of the Sibleys. Born in Providence, Rhode Island, January 28, 1782 , her family represents, on her mother's side, another stream of influence which helped make Marietta, for that place was not entirely a Massachusetts settlement. Colonel Ebenezer Sproat, her father, was born in Middleborough, Massachusetts, in $175^{2}$, and became a surveyor by profession. He entered the Continental army as a captain and rose to the rank of colonel. After the war he resided for a time at Providence, Rhode Island, where he met and later married Catherine Whipple, the daughter of Commodore Abraham Whipple. In 1786 when Congress ordered the first surveys of land west of the Ohio river, the so-called "seven ranges," Colonel Sproat was one of the surveyors who began the work which on account of Indian hostilities had to be given up the following year. When the Ohio Company was organized, Sproat again came west as a surveyor of lands in the region of Marietta. He was joined by his family in 1789 and, until his death in 1805 , made his home in the new territory. As sheriff of the county, he opened the first court ever held in the region which became Ohio. ${ }^{8}$

7 Ibid, $35: 448-449$.

${ }^{8}$ Hildreth, Biographical and Historical Memoirs of the Early Pioneer Settlers of Ohio, 230. Hereafter this book will be referred to as Pioneer Settlers of Ohio. 
Commodore Whipple played a distinguished part in the Revolutionary War, and always claimed the honor of having fired the first gun at the British on the sea under the authority of Congress. He was descended from John Whipple, one of the original proprietors of Providence Plantation and an associate of Roger Williams. Before the war, Abraham Whipple commanded a vessel engaged in the West India trade. Like other traders of his time he was highly incensed at the efforts of Great Britian to put an end to smuggling, and tradition has it that he was the leader of the party of Americans that burned the British ship "Gaspee" in $1772 .{ }^{9}$ After an honorable career in the navy during the Revolutionary War, he resided at Providence, Rhode Island, where his daughter married Colonel Sproat. When Marietta was founded, Whipple moved there with his family. In 180 I when the vessel "St. Clair" was built at Marietta to take a cargo of products to the West Indies, Whipple commanded the vessel on its trip down the Ohio and Mississippi to New Orleans, and thence to Havana. He disposed of the cargo of pork and flour, returned to Philadelphia with a return cargo, sold vessel and cargo, and returned by land to Marietta. This was the first rigged vessel ever built on the Ohio, and Whipple had had the honor of "conducting her to the ocean."

The marriage of Solomon Sibley to Sarah Whipple Sproat was, therefore, not only the union of two important individuals, but also of two important streams of New England influence which poured into the Northwest during this period. With

'At the time of the Gaspee Affair the identity of those taking part in it was kept from the British. When measures had advanced, however, to an open break, the matter was no longer kept secret and a British captain, hearing of Whipple's part in it, sent him the following communication: "You, Abraham Whipple, on the 17 th of June 1772 , burned his majesty's vessel,
the Gaspee, and I will hang you at the yard arm.

To this note Whipple replied:

James Wallace."

"To Sir James Wallace;

Sir: Always catch a man before you hang him.

Hildreth, Pioneer Settlers of Ohio, 159 .

Abraham Whipple." 
the blood of such pioneers coursing in his veins it is little wonder that Henry Hastings Sibley felt the call of the West and pushed on to a new region on the advancing frontier.

Henry Hastings Sibley was born in Detroit February 20, I8II, and grew up in a frontier environment. The region afforded him in his boyhood a good training in field sports and wood lore which was destined to be of great use to him in his own pioneer work. He was educated in the school and academy at Detroit and had two years' instruction in Greek and Latin under an Episcopal clergyman. His parents intended that he should be a lawyer and he spent two years in the study of the law, but this study and the prospects of a legal career in a settled community did not appeal to the young man who was far more interested in a wild life on the frontier. ${ }^{10}$

With the consent of his parents young Sibley gave up his legal studies and left home on June 20, 1828 , going first to Sault Ste. Marie where he secured employment in the sutler's store of John Hulbert. A few months later, he was in charge of the business affairs of Mrs. Johnson, the mother-in-law of Henry L. Schoolcraft, the Indian agent at Sault Ste. Marie. Mrs. Johnson's husband had been a fur trader and here Sibley became familiar with the Indian trade. In the spring of 1830 Sibley secured employment as a clerk with the American Fur Company, at Mackinac. ${ }^{11}$ As his work with the fur company was not to begin until June, Sibley made a trip to Chicago by way of Lake Michigan. In his autobiography he gave the following description of Chicago at that time: "I found on the present site of the Queen City of the Lakes a stockade constructed for defense against the Indians, but abandoned, and perhaps a half dozen dwellings occupied by the Beaubien and other families, and a single store stocked with a small but varied assortment of goods and provisions. A more uninviting

\footnotetext{
${ }^{10}$ Sibley was admitted to the bar in Minnesota in $185^{8}$, the year in which he became Governor. His certificate is among the Sibley Papers (Misc).

11 There is a recommendation of Sibley signed by the President, Cashier and Directors of the Bank of Michigan to the American Fur Company in the Sibley Papers, April 28, 1830.
} 
place could hardly be conceived of. Sand here, there, everywhere, with an occasional shrub to relieve the monotony of the landscape. Little did I dream that I would live to see on that desolate coast a magnificient city of more than a halfmillion of inhabitants, almost rivalling metropolitan New York in wealth and splendor." 12

For the next four years Sibley held this position as clerk, ${ }^{13}$ the duties of which were very exacting during the busy season of the year. It was the duty of the clerks to inspect and list all of the furs brought in by the traders who at that time reported each spring at Machinac. Settlement was then made with the traders on the basis of the credit extended to them the previous summer. After the year's business was thus closed for each trader on the books of the fur company a new supply was issued and a new account opened up. The invoice was made out by the clerks and recorded in the books of the company. After all the traders had thus been fitted out and had departed for the Indian country the furs which had been brought in were sorted and packed for shipment to New York or London. From May or June until August the life of a clerk was a very busy one, but during the other part of the year there was time for recreation and study if one were so disposed and could secure the necessary books. Sibley seems to have utilized his time quite well in this respect. It was at this time that Sibley held his first political office, that of justice of the peace, the commission of which he received when he was twenty-one years old. During the year I833-34 Sibley was supply purchasing agent for the fur company and travelled through Ohio and Pennsylvania buying for the company supplies used in the Indian trade.

12 West, Ancestry, Life and Times of Henry Hastings Sibley, 48-49, quoting Sibley's Autobiography. This Autobiography was never published and is not now among the Sibley Papers. West had access to it and we know of it mainly through the numerous quotations from it in his Life of Sibley.

${ }_{13}$ The American Fur Company was anxious to get young men of ability and promise to enter its employ as clerks and it advanced those who made good. Sibley is a type of young man like they wanted, and his later business career is an illustration of how they would advance those who proved themselves worthy. 
In 1834 the American Fur Company was re-organized, John Jacob Astor retiring from the Company and Ramsey Crooks becoming president. At this time Sibley found himself at a turning point in his career. He received an offer of a position as cashier of a bank in Detroit and a similar offer from a bank in Huron, and had almost decided to accept one of these offers when the way was opened for him to become a partner in the fur company. Two of his friends, Hercules L. Dousman and Joseph Rolette, Sr., had been engaged in the fur trade with headquarters at Prairie du Chien, Wisconsin. They now proposed to Sibley that the three of them make an agreement with the fur company by which the company would furnish the money or advance the goods and the men give their time in extending operations on the upper Mississippi among the Sioux. It was to be Sibley's duty to establish headquarters on the St. Peters river (now called the Minnesota river) and have charge of all the operations in that region. The two friends pictured the wild life on the frontier in such glowing terms that Sibley was induced to decline the offers as cashier and to enter the fur trade. Sibley left Machinac in the latter part of October, 1834, and started for the upper Mississippi country. He went by way of Green Bay and the Fox-Wisconsin route and five days later arrived at Prairie du Chien. Remaining here only a few days, he continued his journey on horseback "through an unexplored and uninhabited wilderness" for a distance of three hundred miles to Mendota, a traders settlement at the junction of the St. Peters and Mississippi rivers.

Two years after his arrival at Mendota, Sibley built a stone house which he used as bachelor quarters until his marriage in 1843 . After Sibley moved to St. Paul, in 1862, this house fell into decay, but was finally restored by the Daughters of the American Revolution and is known today as the "Sibley House." It has been refurnished with many articles used by the Sibleys and is open to visitors. Facts connected with his residence at Mendota furnish a good illustration of the rapidity with which the westward movement passed a given 
place. Concerning his residence here in different political jurisdictions, Sibley, on a later occasion, wrote: "It may seem paradoxical, but it is nevertheless true, that I was successively a citizen of Michigan, Wisconsin, Iowa and Minnesota Territories without changing my residence at Mendota. The jurisdiction of the first named terminated when Wisconsin was organized in 1836 , and in turn lowa extended her sway over the west of the Mississippi in 1838 . When the latter was admitted as a State with very much diminished area, the country lying outside of the State boundaries was left without any government until the establishment of the Minnesota territorial organization placed us where we are." 14 Visitors to the "Sibley House" are shown the room where the Sibley children were born in the different political jurisdictions. In the short space of fourteen years four territories had exercised nominal jurisdiction over the place, and from 1846 to 1848 the region west of the Mississippi had been without territorial organization. Rapid changes of this sort constituted one of the significant features of the westward movement.

uSibley, "Reminiscences of the Early Days of Minnesota," in Minnesota Historical Collections, $3: 265$. 


\section{CHAPTER II}

\section{THE FUR TRADERS' FRONTIER}

As was true in most other sections, it was the fur trade that brought the upper Mississippi country into commercial relations with the civilized world. The presence of Indians on the frontier hastened rather than retarded the settlement of new areas by white men, and among the influences making for settlement the fur trade had a very important relative position. Traders as well as explorers and missionaries went far in advance of the other waves of white settlement, learned the resources of the country, and, the two latter classes especially, made them known to the on-coming tide of immigrants. In a comparatively short time, the fur traders' frontier would pass a given region and the knowledge of the country that had been acquired enabled the pioneers in the next wave of settlement to select the most favorable locations. Not that the fur traders encouraged the other classes to come in; on the contrary, it was to the interest of the fur trader to keep the other classes of whites out of a new region. The westward march of white settlers could not be stopped, however, and it was recognized that the fur traders' frontier was a comparatively short period in the development of a region. With favorable geographic conditions, an abundance of fur bearing animals, and the presence of Indian tribes it was only a question of time until the fur traders' frontier would advance along the upper Mississippi and its tributaries into the region which was destined to be Minnesota. Fur traders came into the region from two directions; some came among the Chippewas by way of Lake Superior, and some came among the Sioux by way of the Mississippi. In the French and British periods of the fur trade in this region the traders for the most part came in by way of Lake Superior, 
although as early as 1774 Peter Pond, a Connecticut Yankee, had come up the Mississippi to trade with the Indians. This study deals principally with the American fur traders' frontier which came up the Mississippi for it was this movement that brought Henry Hastings Sibley to Minnesota. Since Sibley was associated with the American Fur Company it is chiefly its organization and activities that will be described.

The American Fur Company was chartered under the laws of New York in 1808 "for the purpose of carrying on extensive trade with the native Indian inhabitants of America." John Jacob Astor was the founder of the company which gradually extended its field of operations until its activities spread to the Pacific coast. The history of the company falls into two distinct periods with the date 1834 as the dividing line.

It is a well known fact that the British controlled the fur trade of the Northwest until after the War of $1_{8} I_{2}$, the British garrison leaving Prairie du Chien in $1815 .{ }^{2}$ In the following year a law was passed by Congress which prohibited foreign traders from operating within the territory of the United States. ${ }^{3}$ This marked the withdrawal of the British companies from the upper Mississippi country, and made possible the remarkable success of the American Fur Company. Many of the traders and voyageurs who had served under the British fur companies were taken over by the American Fur Company when it came into the region and this fact greatly facilitated the gaining of a practical monopoly of the Indian trade in Minnesota.

Between 1819 , the date of the founding of the military post which was soon called Fort Snelling, and 1834, when Sibley came to Minnesota, several trading posts were established within the limits of what later became Minnesota Territory. The principal post was at New Hope (also called St. Peter and

${ }^{1}$ New York Private Laws, 1808 , p. 160.

"Stevens, "Organization of the British Fur Trade," in Mississippi Valley Historical Review, 3:172-202,

"United States, Statutes at Large, 3:332. 
later Mendota), just across the St. Peters river from Fort Snelling. In I 826 Major Taliaferro, the Indian Agent at that point, listed seventeen posts in the upper Mississippi country. ${ }^{4}$ Most of these belonged to the American Fur Company and were under the control of Joseph Rolette, Sr., whose headquarters were at Prairie du Chien. The American Fur Company made it a practice to form partnerships with men of proved ability as fur traders by which the company furnished the goods to the trader on credit, the trader gave his time, and the profits were divided between them. It was in this sense that the American Fur Company operated in Minnesota. Credit was thus extended to Rolette and Dousman on the books of the American Fur Company simply as one of their "outfits." The accounts were closed each year with each "outfit" and the balance paid to, or the deficit charged against, the "outfit." The division of the country that was assigned to Rolette extended from Dubuque's lead mines up the Mississippi to a point above the Falls of St. Anthony and up the St. Peters river to its source. Rolette brought his goods each summer from Mackinac, by way of the Fox-Wisconsin route, to Prairie du Chien where the goods were put up in lots for each trading

These posts were located as follows: Fort Adams, Lac Qui Parle........................ Columbia Fur Co.

Fort Washington, Lac Travers

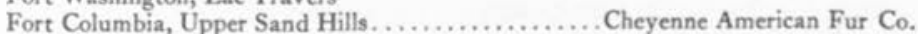

Fort Biddle, Crow Island. ..................... American Fur Co.

Fort Rush, at mouth of Chippewa............... " * "

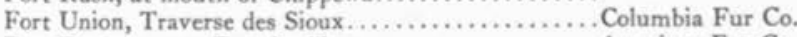

Fort Factory, near Fort Snelling. ................ American Fur Co.

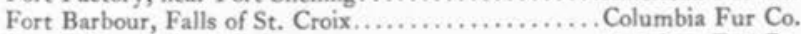

Fort Calhoun, Leech Lake..................... American Fur Co.

Fort Bolivar, Leaf Lake......................... Columbia Fur Co.

Fort Pike, Red Lake............................ American Fur Co.

Fort Rice, Devil's Lake...................... " " "

Fort Greene, Big Stone Lake................. u. u “

Fort Southard, Forks of Red Cedar, ............. " * " "

Fort Lewis, Little Rapids (St. Peters river).......... " " " "

Fort Confederation, second forks of the Des Moines

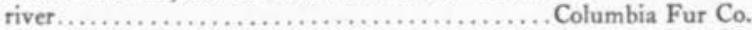

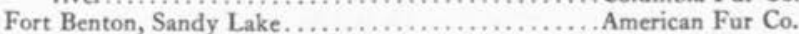

Taliaferro to Alexis Bailly, April 2, 1826, in Sibley Papers. Also Neill, "Fort Snelling from 1819 to 1840 ," in Minnesota Historical Collections, 2:113-114. For location of these posts see accompanying map. 
post and sent up the Mississippi in charge of clerks hired for the purpose. These clerks, or subordinate traders, had charge of the various posts and were not heard from until the following spring when they returned with the furs and peltries. The

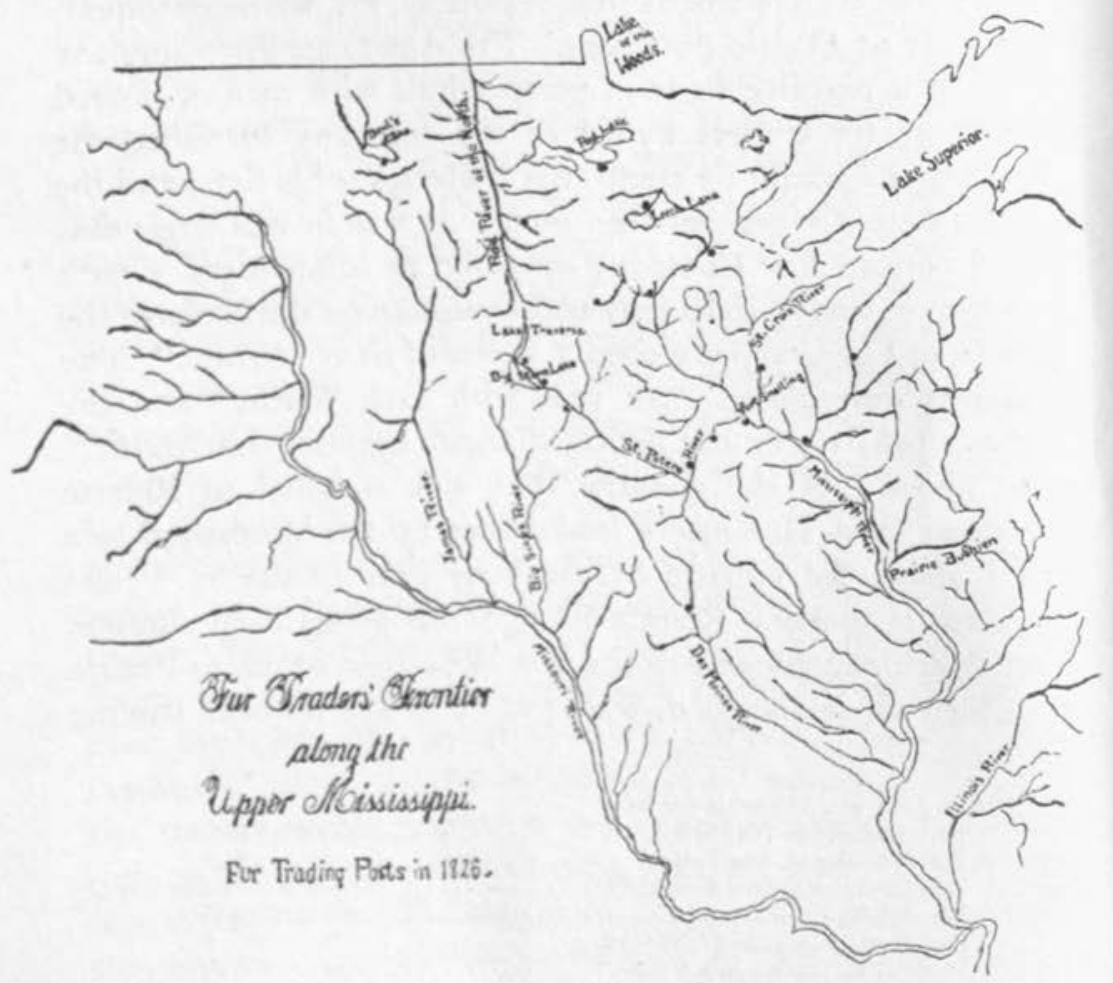

clerks or traders, as the case might be, gave the goods out to the Indians on credit. The Indians then went out on their hunts and returned in the spring for settlement with the trader. The goods were sold to the Indians at a profit of $100 \%$ on most articles, and even more on lead, powder, knives, and similar articles, where the profit was sometimes $300 \%$ or $400 \%$, or even higher. In the spring, the Indians settled according to their success on the chase, some paying all their debts, some only part, and some none at all. Credits were extended to the 
Indians in proportion to their ability as hunters and their honesty in making settlement. ${ }^{5}$ Since the goods were given out at such high prices the trader made a good profit even if he lost a considerable amount on poor debtors. An account was kept, however, of unpaid balances of the Indian debts and were invariably presented when Indian treaties were made. ${ }^{6}$

As has been previously related, Sibley came to the upper Mississippi country in 1834 as a partner in the American Fur Company, jointly with Rolette and Dousman. The country that had formerly been under Rolette was divided, and Sibley took charge of all the country from Lake Pepin to the Little Falls of the Mississippi, north and west to Pembina in the Red River valley; also all the valley of the St. Peters river and westward to the sources of the streams which flowed into the Missouri river. When Sibley made his first tour of inspection of the posts under his charge, in 1835 , he found the following men in charge of the most important posts: Joseph R. Brown at Lac Traverse; Joseph Renville at Lac Qui Parle; Louis Provencalle at Traverse des Sioux; Jean B. Faribault at Little Rapids; Joseph Laframboise at Coteau de Prairie at Lake of the Two Woods; and Alexander Faribault at Cannon river. Other prominent traders in the region at the time were Alexis Bailly, Norman W. Kittson, James Wells, Hazen Mooers, Philander Prescott, and Francois Labathe. ${ }^{7}$ These men had been in the region for some years and some of them were destined to play a large part in the making of Minnesota. The story of the lives of these men is, to a very large extent, the history of this phase of the fur trade before Sibley came into the region.

Jean B. Faribault was one of the older men then engaged in the Indian trade in Minnesota. He was born in 1774 and

'Thomas Forsyth to Lewis Cass, Secretary of War, quoted in Chittenden, American Fur Trade, 3:926-930.

6 "The American Fur Company ought to be satisfied with the Indians, for they have monopolized all the trade. They have monopolized the whole trade on the frontiers together with the Indian annuities, and everything an Indian has to sell, yet they claim a large amount for debts due them for non-payment of credits given the Indians at different periods." Forsyth to Cass, quoted in Chittenden, American Fur Trade, 3:930. See also Chapter VI below.

7 Sibley, "Reminiscences of the Early Days in Minnesota," in Minnesota Historical Collections, $3: 245-248$. 
entered the fur trade in 1798 with the Northwest Fur Company; He first came to the St. Peters river in I804. After ten years' experience with the Northwest Fur Company he began business for himself at Prairie du Chien, where he refused to take part in the War of 1812 against the United States. After the war and the withdrawal of the British influence from the Northwest, he secured a supply of goods from Joseph Rolette, of the American Fur Company, and, henceforth, was one of their most reliable traders. ${ }^{8}$

Alexis Bailly, with whom Sibley made the trip from Prairie du Chien to Mendota in 1834 , had been engaged in the fur trade since 1822 . He was at New Hope (now Mendota) during most of this time and had considerable trouble with Major Taliaferro, the Indian Agent, over the use of liquor in the Indian trade. ${ }^{9}$ In 1832 William Aitkin wrote to Sibley, who was then a clerk at Mackinac, that "Baillie's people" were their "worst neighbors" at Sandy Lake "after the Hudson Bay Company," and that Bailly was well supplied with liquor and had "a predominant sway in the Indian trade." 10 Bailly sold out his interests at Mendota to Sibley in 1835 .

Joseph R. Brown, a man whose name will be mentioned many times in this study, because he too was one of the makers of Minnesota, came into the region in 1819 as a drummer boy with the detachment of soldiers under Colonel Leavenworth to build the military post that was soon called Fort Snelling. Leaving the army about 1825 , he engaged in the Indian trade and early lumbering enterprises and became a typical product of the frontier. "A drummer boy, soldier, Indian trader, lumberman, pioneer speculator, founder of cities, legislator, politician, editor, inventor, his career, though it hardly commenced till half his life had been wasted in the obscure solitudes of this far Northwestern wilderness, has been a very remarkable and characteristic one, not so much for what he

"Sibley, "Memoir of J. B. Faribault," in Minnesota Historical Collections, 3:168.

Neill, "Fort Snelling from 1819 to $1840, "$ Minnesota Historical Collection, $2: 112$.
Aitkin to Sibley, February $10,183^{2}$. 
has achieved, as for the extraordinary versatility and capacity which he has displayed in every new situation." ${ }_{11}$

Most of these traders married Indian women and exercised considerable influence with the tribes into which they married. They were men who had personalities strong enough to enforce order among their suboidinates and among the Indians with whom they traded, in a country where laws were practically unknown. Sibley always insisted that the old traders were a remarkable class of men who were much better than they were generally reputed to be. "Perhaps no body of men," he wrote, "have ever been so misunderstood and misrepresented.They have not only been accused of all the evils and outrages that were the accompaniments of extreme frontier life, where law is unfelt and unknown, but they have been charged with fraud and villainy of every conceivable description. With too much self-respect to contradict charges so absurd and improbable, and with an undue contempt for public opinion, it is not surprising that scarcely a voice has been raised, or a pen wielded in his behalf. There is an unwritten chapter yet to be contributed to the records of the Northwest, which will place the Indian trader in a proper light before the country, while it will not seek to extenuate either his defects or vices." ${ }^{12}$ Since the traders were a class of men distinct from other men in modes of thought and life they cannot justly be measured by the same standards which apply to men in civilized communities, and particularly to men of a later day. It must be said of them that while they generally had little education ${ }^{13}$ they possessed re-

\footnotetext{
${ }^{11}$ Sibley related the following story regarding the methods of keeping accounts by Louis Provencalle, one of his traders: "He kept his Indian credit books by hieroglyphics, having a peculiar figure for each article of merchandise, understood only by himself, and in marking down peltries received from the Indians, he drew the form of the animal, the skin of which was to be represented. He also had a mode of indicating the names of his Indian debtors on his account books peculiar to himself." Sibley also illustrated the power of a trader over the Indians by relating how Provencalle saved his goods on one occasion when a band of Sioux threatened to pillage them. Provencalle "seized a fire brand and, holding it within a few inches of an open keg filled with gunpowder, he declared his determination to blow them and himself into the air if they seized upon a single article." It is needless to say that he was not further annoyed. Sibley, "Reminiscences Historical and Personal," in Minnesofa Historical Collections, $1: 381-382$.
} I: $378-379$.

"Wheelock, "Memoir of Joseph R. Brown," in Minnesota Historical Collections, 3:212.

${ }^{12}$ Sibley, "Reminiscences Historical and Personal," in Minnesota Historical Collections, 
markable energy and honesty. "In fact the whole system of Indian trade was necessarily based upon the personal integrity of the employer and the employed. Generally speaking, the former resided hundreds or even thousands of miles distant from the place of trade, and he furnished large amounts of merchandise to his agent or clerk for which he held no security but his plighted faith." "The characteristic of honesty which the old traders displayed in their dealings with the employer did not extend to rival traders. "There was a state of perpetual warfare existing between rival establishments in the Indian country, except in case of sickness or scarcity of provisions, when hostilities ceased for a time and the opposite party came to the rescue of those who were in distress and afforded every assistance possible. Such exhibitions of qualities so contradictory were characteristic of all the old class of Indian traders." 15

The voyageurs, composed entirely of French Canadians who were engaged in Montreal for a term of three years at regular wages, were of two classes, the "Mangeurs du lard" or pork-eaters, during their first three years in the West, and the "hivernants" or "winterers," composed of those who had passed the apprenticeship stage. The labor performed by these men in winter was excessively severe. They frequently carried packs weighing from fifty to one hundred pounds for days in succession in reaching Indian camps with goods or in returning with loads of furs. The most disobedient of the voyageurs, on their way out from Montreal, were sent to points on the Minnesota river where the traders "had a reputation for sternness and severity towards their men," 16 Sometimes the voyageurs

who sought employment with the fur good families back farther east. "Many of the young men region by a love of adventure and of the chase than bere, like myself, more attracted to this wild was always enough of danger, also, to give zest ton by any prospect of pecuniary gain. There

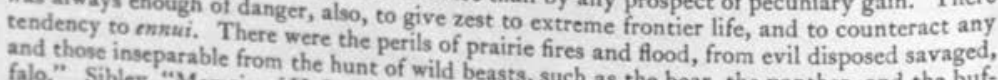
falo." Sibley, "Memoir of H. L. Dousman," ints, such as the bear, the panther, and the bufI:380.

"Sibley, "Reminiscences Historical," in Minnesota Historical Collection, 3:195.

15:380.
Iections, 3:245, "Reminiscences of the Early Days in Minnesota" in Minnesota Historical Col- 
tried to escape from the hardships by deserting, but in such cases they were hunted down and brought back.

After Sibley came to Mendota, the traders in his division reported to him in the spring and received their goods from him instead of reporting at Prairie du Chien as had formerly been the case. The furs were then packed and shipped down the river to Prairie du Chien and on to Machinac. In other words, Sibley was the medium of communication between the individual trader and the fur company officials in the east. The amount of furs received from the Sioux Outfit (Sibley's division at Mendota) was enormous. ${ }^{17}$

An idea of the profits in the Indian trade, assuming that all the Indian debts were paid, may be formed from the table on page $20 .{ }^{18}$

${ }^{17}$ The following table, taken from Sibley Papers (Misc.) 1835 , will show the prices of furs as well as the amount shipped out:

\begin{tabular}{|c|c|c|}
\hline 9,388 & 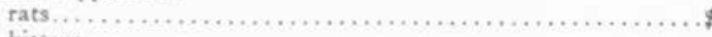 & $44,702.08$ \\
\hline $2,5^{88}$ & 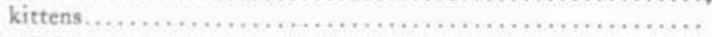 & $5^{1} \cdot 3^{6}$ \\
\hline 1,027 & 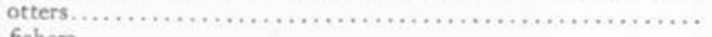 & $5,135.00$ \\
\hline 609 & 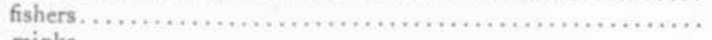 & 913.50 \\
\hline $2,33^{\circ}$ & 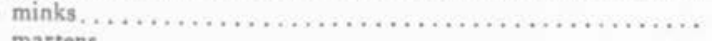 & 698.40 \\
\hline 462 & 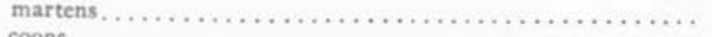 & 577.50 \\
\hline 2,011 & 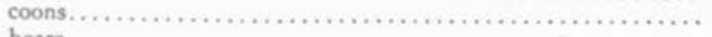 & 603.30 \\
\hline $1 \infty$ & 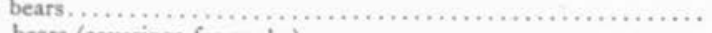 & $216 . \infty$ \\
\hline 24 & 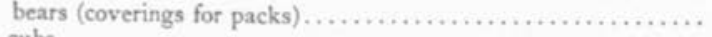 & 24.00 \\
\hline 63 & 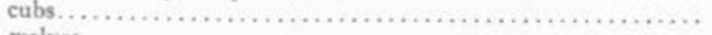 & $94 \cdot 50$ \\
\hline 34 & 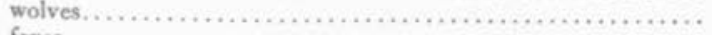 & $17 . \infty$ \\
\hline 205 & 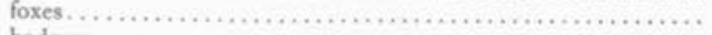 & 153.75 \\
\hline 12 & 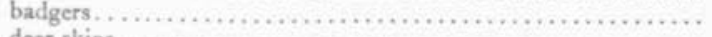 & 2.25 \\
\hline 3,243 & 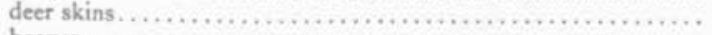 & 972.90 \\
\hline 225 & 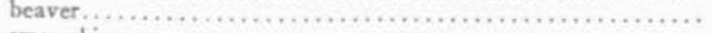 & $900 . \infty$ \\
\hline 80 & 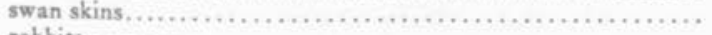 & 80.00 \\
\hline & 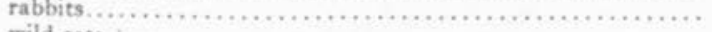 & $\cdot 3^{8}$ \\
\hline & 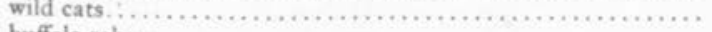 & $1 . \infty$ \\
\hline 1,039 & 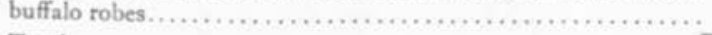 & $4,756,00$ \\
\hline & ...... & \\
\hline
\end{tabular}

${ }^{18} \mathrm{Neill}$ "Fort Snelling from $\mathrm{r} 8 \mathrm{rg}$ to $1840^{\circ}$ in Minnesota Historical Collections, $2: 13 \mathrm{r}$. The column showing gain $\%$ has been added to the table by the present writer. 


\begin{tabular}{|c|c|c|c|c|c|c|c|}
\hline \multicolumn{2}{|c|}{ St. Louis prices } & \multicolumn{4}{|c|}{ Minnesota prices } & \multirow{2}{*}{$\begin{array}{l}\text { Net gain } \\
\$ 8.75\end{array}$} & \multirow{2}{*}{$\begin{array}{c}\text { Gain \% } \\
284 \%\end{array}$} \\
\hline 3 pt. blanket & $\$ 3.25$ & 60 & rat $\mathrm{s}$ & kins & $\$ 12.00$ & & \\
\hline I $1 / 2$ yd. stroud & 2.75 & 60 & “ & “ & $12 . \infty$ & 9.25 & $336 \%$ \\
\hline I N. W. Gun & 6.50 & 100 & “ & “ & $20 . \infty$ & 13.50 & $200 \%$ \\
\hline I lb. lead & .06 & 2 & “ & “ & .40 & $\cdot 34$ & $566 \%$ \\
\hline I lb. powder & .28 & 10 & “ & “ & 2.00 & 1. 72 & $614 \%$ \\
\hline I tin kettle & 2.50 & 60 & “ & “ & 12.00 & $9 \cdot 5^{\circ}$ & $3^{80 \%}$ \\
\hline I knife & .20 & 4 & “ & “ & .80 & .60 & $300 \%$ \\
\hline I looking glass & .04 & 4 & “ & " & .80 & .76 & $1900 \%$ \\
\hline I lb. tobacco & .12 & 8 & “ & “ & I. 60 & I. 40 & $1166 \%$ \\
\hline
\end{tabular}

There was an additional profit for the fur company in the sale of the furs. In 1836 , Sibley's buffalo robes, for which he paid $\$ 4.00$ each in trade in Minnesota, were sold in Michigan for $\$ 6.00$, thus making an additional profit of $50 \%$, less transportation charges from Mendota to Machinac. ${ }^{19}$ The rats, for which an average of about fifteen cents had been paid in trade in Minnesota, were sold for twenty cents, a profit of $33 \frac{1}{2} \%$, less transportation charges. The profit on other furs varied, but their sale usually added a good profit to the company's account. On the other hand, the furs from Minnesota sometimes got to market at an unfavorable time and had to be sold much lower than those prices, sometimes even at a loss.

The fur trade in Minnesota was in its most flourishing condition in the years immediately preceding 1837 . New trading posts were established during this period, particularly in the region of the Red River of the North. ${ }^{20}$ Prices of furs were higher in 1836 than they had been for years ${ }^{21}$ and higher, in

19 Ramsey Crooks to Sibley, September 14, 1836 .

21 "We have just ley, July 22, 1836 .

better than for years learned the result of the London sales. All the Western Outfit skins sold all sold, the ist brought 20 cept bears which I fear continue to sell poorly. . . . Y Your rats are to Sibley, April 27,1836 . 
fact, than they were to be after I837. Buffalo robes sold better than other furs in the London market, while otters, beaver, and rats did not sell as well in the European market as they did in America. ${ }^{22}$

There was no metallic money used in the fur trade at this time, the trade being carried on entirely by barter. The standard of value during the early period of the fur trade was a prime beaver called a "plus" by the French. In the later period the unit of value in Minnesota was the muskrat. ${ }^{23}$

About the only thing to interfere with the fur trade during this period was the relations between the traders and the Indian Agent, Major Taliaferro, who said in a circular issued to the traders that most of them were disregarding the provisions in their bonds regarding the introduction of liquor into the Indian country. He threatened to withhold licences from the traders "whose creditors may hereafter obtain ardent spirits from any source and introduce the same within the limits of the agency." ${ }_{24}$ There was also some trouble over the fact that the Sioux in the Lac qui Parle region were hostile to the Chippewas, contrary to their treaty. Major Taliaferro threatened to suspend all trade with the Sioux unless they ceased their hostility, and he directed Joseph Renville, the trader at that point, to bring to Fort Snelling all Sioux who had been hostile towards the Chippewas. ${ }^{25}$ The traders were incensed at the high-handed methods of the Indian Agent, and Sibley lodged a complaint and protest with the department at Washington against Taliaferro's proposed suspension of the trade. Ramsey Crooks interested himself in the matter, but he did not believe that Taliaferro would actually suspend all trade with the Sioux. ${ }^{26}$ The trade

\footnotetext{
$z$ "Buffalo robes are above all others the surest of selling well and promptly. They have

become an article of necessity." Ramsey Crooks to Sibley, September 14, 1836 . $12: 67 x$.

24 Circular Notice, August 1835 , in Sibley Papers.

\$s Taliaferro to Sibley, Dec. 8,1835 .

\$o "All your complaints against Maj.

quite strange to me that he against Maj. Taliaferro are doubtless well grounded, . . . It is January in the me that he should annoy you as he does, for he wrote to me on the rst of last by saying that most friendly manner complimenting you in the highest terms and concluded Apr. 27,1836 .
} 
was not suspended and after a time conditions on the frontier assumed their normal character.

The year 1837 marked a turning point in the history of the fur trade in Minnesota. Up to this date all the lands within the limits of the future Minnesota Territory belonged to the Indians, except the military reserve at Fort Snelling. In 1837, however, a delegation of Sioux Chiefs was taken to Washington and a treaty was negotiated for the cession of lands east of the Mississippi. ${ }^{27}$ This treaty was made primarily to open up the pine forests of the St. Croix valley to the lumberman, the advance guard of the next wave of civilization. It was, of itself, a signal that the fur traders' frontier would soon be passing farther to the West. As has been shown, the fur trade in Minnesota reached its peak of production about this time, and the year 1837 marks the beginning of the decline.

The Indians underwent a marked transformation when the white settlements, in their gradual but steady advance, made necessary the negotiation of the first treaties for the cession of lands. The Indians were not only demoralized by contact with the whites, but they ceased to rely upon their own efforts to support themselves and their families and came to depend more and more upon the annuities from the government." This was the second great transformation that came in the life-history of the Indian tribes. Before the fur traders' frontier touched a given tribe of Indians the red men supported themselves by agriculture or the chase, or by both; with the coming of the traders the Indians came to rely more and more upon the supplies which were brought into the Indian country by the traders and which could be obtained by the exchange of furs; with the negotiation of treaties for the cession of land

"Neill, "Fort Snelling from 1819 to 1840 ," in Minnesota Historical Collections, 2:1 32-133.

\% "The decay of the Dakotas in our midst may be dated from the time of their treaty in 1877. ... The policy which has been pursued to secure the lands of the Indian and then to der him so inducement to improve his condition has been the bane of his race. Recourse to figuer and other evil habits are but the natural consequences of that system which drives him free his bone, interferes with his habits of life, and regards him as an cutcast from the land of Fis fathers, without holding out to him any promise for the future." Sibley, "Reminiscences Hintorical and Pernonal," in Minnesola Historical Collections, $1: 319$. 
the Indians came to rely upon the annuities and less upon the collections of furs. This fact, together with the growing scarcity of fur-bearing animals in the region, brought about a decline in the fur trade. This does not mean that the total amount of trade carried on with the Indians necessarily decreased. There is a distinction between the "fur trade" and the "Indian trade." After the government began to pay annuities, the Indians could pay for their goods partly in money, and thus the fur company began a retail business. The traders were certain to be on hand with supplies of goods at the time of the payment of annuities, and the Indians were not long in spending their money. 20 They found it necessary then to buy goods on credit from the traders until the next payment of annuities from the government, and these bills were not always paid in full. These balances were carried year after year by the traders as had been done in the days of the fur trade. It must not be supposed that this transformation was a sudden one; on the contrary, it was very gradual, the fur trade and the retail trade being carried on at the time by the fur company. In the years after 1837 , however, the retail trade increased relatively. With the appearance of white men other than traders the retail trade naturally extended to them. When white settlement increased still more, the fur company undertook banking operations, making loans, cashing drafts brought into the region by prospective settlers, and selling exchange on the New York office to those who wished to send money out of the region. ${ }^{20}$ This transformation of a fur trading enterprise into a general mercantile and financial establishment is typical of the evolution of institutions in a frontier community.

Another change that came over the fur company's methods after 1837 was the change of route of shipping goods into the

w In 18,3 when the money was received under the Treaty of 1837 , nineteen Indians (half-breeds) deposited 9500 each with Sibley as trastee and traded the amoent out in merchandice. These accounts extended over a period of years, some as late as 1847 . Sibley kept an accurate account with each Indian and allowed him $6 \%$ interest on balances due each year. Sibley's Caxh Book, 18,38 , in Library of Minnesota Historical Society. 2:115-119.

Patchin, "The Development of Banking in Minnesota," in Minnerete Hiatery Bulletin, 
upper Mississippi country. It has already been shown that in the early days of the fur trade the goods were sent from New York to Mackinac, thence via Prairie du Chien to Mendota. In 1838 Sibley was purchasing his goods for the Indian trade through P. Chouteau \& Company, of St. Louis. ${ }^{31}$ At that time the goods were still sent by way of Albany and Buffalo, but by I 840 the goods were coming by way of Philadelphia and Pittsburg, by river to St. Louis and thence up the Mississippi to Mendota. ${ }^{32}$ Sometimes, even, goods were shipped from New York to New Orleans and thence to St. Louis and to Mendota. A commission of $5 \%$ was paid Chouteau \& Company for handling this business for Sibley's "Outfit" of the American Fur Company. This was the opening wedge for the St. Louis company, and in $184 \mathrm{I}$ they began to secure furs from Minnesota, thus challenging the monopoly of the American Fur Company. ${ }^{33}$

Prices of furs declined after 1837 , partly due no doubt to the financial crisis of that year, and the American Fur Company found itself in close financial straights for some years. ${ }^{34}$ But for the fact that Sibley's outfit was engaging more and more in retail business there would have been a corresponding change in his fortunes. The decline in the price of otters and rats, the

a "Invoice of Mdse, purchased in N, Y. by the American Fur Company and forwarded via Albany \& Buffalo to Messrs. Pratte Chouteau \& Co., St. Louis, to be by them forwarded to Mr. Henry H. Sibley, Fort Snelling, for Fort Snelling Outfit." Inooice Book, 1838 , in Minnesota Historical Society Library.

ansoice Book, 18 po.

"Several letters are in the Sibley $\mathrm{P}_{\text {apers regarding this change. The name "American }}$ Fur Company" was applied to Sibley's business for many years after the change was made to Chouteau \& $\mathrm{Co}$.

a "The Leipsic Fairs have a controlling influence in determining the value of Deerskins \& Shipping Furs, and the result of the Fair last month was the worst that has been known for years. The prospects are most discouraging for the coming sales, which can not possibly be good; but we cannot tell how bad they will be." Crooks to Sibley, June 28, 1841. 
chief furs gathered at this time in Minnesota, made a considerable difference in the total output of furs from the region. ${ }^{35}$

A comparison of the amount of furs collected by a given trader at different periods may throw some light on the trend of the fur trade, particularly if he was in about the same region at the different periods. Jean B. Faribault's account for furs collected in 1835 was $\$ 6,722.54$; in 1839 it was $\$ 2,900$; in 1843 it was $\$ 2,009.66$; and in 1847 it was only $\$ 1,511.75$. On the other hand, the total amount of credit extended to him did not so materially change during the period. In 1835 , when there was no money in circulation among the Indians, the amount of his furs was approximately the amount of his trade. In 1843 the total credit extended to him was $\$ 3,931.22$ and in 1847 it was $\$ 6,439.54$, as compared with a return in furs of $\$ 2,009.66$ and $\$ 1,511.75$ respectively for those years. This difference represents the growth in retail trade, plus balances being carried against the Indians. In $1842-43$ the total amount of credit extended to certain men in the Indian trade by Sibley's outfit was $\$ 24,780.34$ and the amount of furs collected was $\$ 13,215.01$, leaving a balance of $\$ 11,565.33$ which was paid partly in cash and in part was carried as an unpaid balance against the Indians, to be brought up later at the time of making treaties. The total amount of business as shown by the books of the fur company for $1842-43$ was $\$ 52,862.91$ and the total amount, as far as it is possible to separate the accounts, extended to fur traders was $\$ 39,809.98$ The difference between

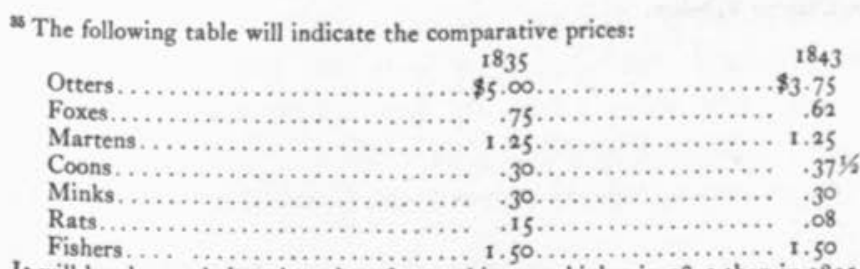

It will be observed that the price of coon skins was higher in 1843 then in 1835 and that martens, minks, and fishers were the same price as in 1835 . Reference to the table given above in this chapter will show, however, that martens, fishers, and coons were not as important in the fur trade in Minnesota as rats and otters. With no change in prices except otters and rats, the total output in 1835 at the prices of 1843 would have been $\$ 21,530.91$ lower than it was. These figures are taken from Sibley's Daily Memorandum Book, Jan. 2, 1843 . 
these amounts, $\$ \$_{3}, 052.93$, represents the probable amount of retail trade for that year. For the year $1846-47$ the total credit business was $\$ 70,870.52$ and the part that can be distinguished as extended to fur traders was $\$ 51,184 \cdot 38$, leaving balance of $\$ 19,686.14$ as the probable amount of retail trade for the year. The largest amount of credit extended to any single fur trader in $1846-47$ was $\$ 11,907.98$ extended to N. W. Kittson who was stationed in the region of the Red River of the North and was thus keeping up, in a way, with the fur traders' frontier in its westward march. ${ }^{36}$

After Sibley's entrance upon his public career in 1848 , his business interests at Mendota were looked after by his brother, Fred Sibley, while Dr. C. W. Borup, who had been engaged in the trade farther up the Mississippi, came to St. Paul and took charge of the business there belonging to Sibley's concern. Borup was an individual who looked out primarily for his own interests, in characteristic frontier fashion, and tried to discredit Sibley with Chouteau \& Company in order to supplant him in the Indian trade. As a result of the work of this man, together with other influences, Sibley found himself embarrassed in his political aspirations because of his connection with the fur company and, as a result, he closed up his connection with the fur trade in 1853 , soon after his retirement from Congress. ${ }^{37}$

These figures are taken from the books of the fur company as kept by Sibley, which are

to be found in the library of the Minnesota Historical Society.
n See Chapter V, below. 


\section{CHAPTER III}

\section{THE PIONEER DAYS ON THE UPPER MISSISSIPPI}

The second wave of civilization to come up the Mississippi made its appearance in the last years of the decade of the thirties. The Treaty of 1837 with the Indians was both a result and a cause of this movement of population. The extensive pine forests on the St. Croix and the upper Mississippi rivers were sure to attract lumbermen in time, and some pine logs were cut on the St. Croix even before the treaty was negotiated. Joseph R. Brown, the pioneer in so many enterprises, seems to have been the man who made the beginning in the industry that was for many years the chief source of wealth in Minnesota after the passing of the fur traders' frontier. ${ }^{1}$ The year $\mathrm{I} 837$, which was the turning point in the fur trade, marked the real beginning of lumbering on the St. Croix.

Although the treaty was made with the Indians, the lands ceded to the federal government were not surveyed and sold for many years. The early lumbermen, as well as the pioneer farmers and even town promoters, were, therefore, squatters upon the public domain, the latter two classes relying upon their land claim associations to secure their title to the lands. A small technicality like not having a legal title to the lands did not in the least interfere with the on-coming wave of pioneer lumbermen. The timber was there and the settlements down the river needed lumber; this was sufficient justification for cutting it. Moreover, these pioneers reasoned that what belonged to the people collectively belonged to them individually as "citizens inheriting an interest in the government," and

${ }^{1}$ Joseph R. Brown "is said to have brought down the first raft of pine lumber that ever descended the St. Croix river." Sibley "Reminiscences Historical and Personal," in Minnesota Historical Collections, $1: 383-384$. Also Durant, "Lumbering and Steamboating on the St. Croix," in Minnessta Historical Collections, 10:648. By 1850 lumbering rivaled the fur trade as the dominant interest in Minnesota. Robinson, Economic History of Agriculture in Minnesofa, 39. 
that they were rendering valuable service to the government, as squatters always reasoned, by creating a value and demand for the public lands. ${ }^{2}$

The first real "outfit" on the St. Croix was established in I 837 by John Boyce at the mouth of the Kanabec or Snake river. $^{3}$ In the same year Franklin Steele built a cabin at the Falls of the St. Croix, and four other parties soon followed his example. Saw mills were set up at St. Croix Falls and Marine Mills in 1838 , at Stillwater in 1843 , at Osceola, Wisconsin, in 1845, and at Lakeland and Arcola in 1848 . The first lumber placed on the market came from Marine Mills in the summer of 1839 . It has been estimated that perhaps one-third of the logs cut on the St. Croix, and later those from the upper Mississippi, were rafted down the river to Rock Island and Moline, Illinois, and even to St. Louis. Much of the lumber sawed in the region was also made up into rafts and taken to market in the same manner. ${ }^{4}$

In 1837 Sibley, Warren, and Aitkin made a contract with the St. Croix and Sauk River bands of Chippewas by which permission was secured from the Indians to cut timber for a period of ten years on the lands adjacent to the Snake and St. Croix rivers, to a distance of one mile on the east side and three miles on the west side of the rivers. The Indians agreed not to molest the contractors or their lumbermen, and also agreed not to permit anyone else to cut timber in the region. In return for this concession, the contractors agreed to furnish the following articles to the Indians: " $500 \mathrm{lbs}$. of gun powder, $1250 \mathrm{lbs}$. of lead, $300 \mathrm{lbs}$. of tobacco, 2 bbls. flour, I bbl. pork, I bbl. salt, $1 / 2$ bbl. of tallow, 45 bu. corn, 5 pieces of Indian 2 "The first operators in the pine districts of Wisconsin and Minnesota were pioneers who
ventured into this new and unexplored country for the purpose of cutting timber for a livelihood,
not with the spirit of speculation. The not with the spirit of speculation. They opened the country for settlement and cultivation, greating a value for the public domain. . . It was generally conceded to be a benefit to the government." Folsom, "History of Lumbering in the St. Croix Valley," in Minnesota Historical
Collections, 9:296.

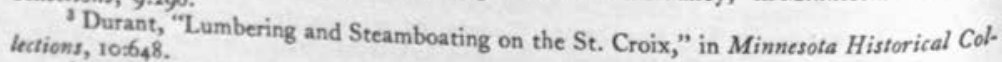

"Stanchfield, "History of Pioneer Lumbering on the Upper Mississippi," in Minnesota Historical Collections, 9:325. 
calico, Io doz. scalping knives, $1 / 2$ gross fire steels, I gross Indian awl blades, 1000 gun flints, $1 \mathrm{~m}$. needles, $6 \mathrm{lbs}$. cotton thread, and $8 \mathrm{lbs}$. of vermillion." ${ }^{\prime}$

Once a beginning had been made, other lumbermen came into the region. In addition to those named above, Orange Walker, John McKusick, Mowers, Loomis, Elam Greely, and the Taylor brothers were all in the region in the late thirties or early forties. ${ }^{6}$ The lumbering industry made several early Minnesota towns, chief of which were Stillwater, on the St. Croix, and St. Anthony, on the Mississippi. John McKusick was at Stillwater as early as 1844 . Franklin Steele staked out a claim on the east side of the Mississippi at the Falls of St. Anthony as early as 1838 , but the first saw mill did not begin operations at St. Anthony until the autumn of 1848 . Lumbermen from New England came in large numbers to this settlement and gave it the appearance of a thriving New England village. ${ }^{7}$

John Catlin, a man who played an important part in the organization of Minnesota Territory, as will be described later, wrote to Sibley, then the territorial delegate in Congress from the region that became Minnesota, wanting a government permit for a mill on the upper Mississippi within that portion ceded to the United States by the Indians. "The United States are getting nothing," he wrote, "for the lumber cut from the lands on the St. Croix \& Chippewa rivers and I see no good reason why the same privilege of cutting timber should not be extended upon the upper Mississippi, particularly as the lumber is wanted at St. Paul and St. Anthony Falls and the country adjacent for permanent improvements which would so much enhance the value of the government lands already in the market."8

\footnotetext{
'This contract, dated Mar. 13, 1837 , was signed by forty seven Chippewa Indians and by Sibley, Warren, and Aitkin, and is in the Sibley Papers. $\mathbf{r}: 39 \mathrm{r}$,

"Sibley, "Reminiscences Historical and Personal," in Minnesola Historical Collections,

'Stanchfield, "History of Pioneer Lumbering on the Upper Mississippi," in Minnesole Historical Collections, 9:321.

- Catlin to Sibley, Jan. 21, 1849.
} 
The lumbering industry was responsible for the coming of the next class of white settlers, the pioneer farmers. In the period of beginnings, the lumbermen secured their provisions and supplies, for men and horses or oxen, from the settlements down the Mississippi. It was not long, however, until some of the settlers recognized the fact that Minnesota might have agricultural possibilities and that pioneer farmers could have a ready market for their surplus products among the lumbermen. ${ }^{9}$ Joseph Haskell and James S. Norris, so Sibley wrote, were "the first farmers who made Minnesota their home and who demonstrated that our lands are equal to any other in the West for the production of cereals, a fact which was denied not only by men not residing in the territory, but by individuals among us." 10 The census of 1840 stated that St. Croix county, Wisconsin Territory, which included the region between the St. Croix and the Mississippi together with a part of the present State of Wisconsin, produced 8,014 bushels of potatoes and 606 bushels of corn. Agriculture as an independent occupation did not yet exist, but it came into existence between 1840 and 1850.11 There had been some stock raising in the Minnesota region among the fur traders in the decade of the thirties when Joseph Renville, at Lac Qui Parle, owned "sheep by the hundreds and cattle by the score." 12 As the decade of the thirties was the heyday of the fur trade in Minnesota, so the decade of the forties found lumbering the predominant industry and the decade of the fifties marked the transition to agriculture.

As has already been indicated, the early settlers in Minnesota were dependent upon the navigation of the Mississippi.

\footnotetext{
'Stanchfield, "History of Pioneer Lumbering on the Upper Mississippi," in Minnesola
rical Collections, 9:321. 1:391.

${ }^{10}$ Sibley, "Reminiscences Historical and Personal," in Minnesota Historical Collections,

11 Robinson, Economic History of Agriculture in Minnesota, 39.
${ }^{12}$ Sibley, "Reminiscences Histo

1:391. This is an illustration Historical and Personal," in Minnesota Historical Collections, different stages in "the procession "ranch" as a stage in the history of the West. For the in American History, 12. For a civilization" across the continent see Turner, The Frontier named book in Mississippi
} 
The first steamboat to come up the river as far as Fort Snelling was the "Virginia" which arrived at that point on May I0, I 823 , thus demonstrating that it was practicable for steamboats to navigate the upper Mississippi as far as the St. Peters river. ${ }^{13}$ There was no regular steamboat line established, however, until 1847 when a company was formed, Sibley being one of the company, to run a regular line of packets from Galena to Mendota. Before this time only stray boats made trips to this region whenever they had paying cargoes. ${ }^{14}$ Since Minnesota was so far North, this means of transportation was, of course, available only between April and November. ${ }^{15}$ This was a serious handicap to the settlements on the upper Mississippi until the coming of the railroad in the decade of the sixties.

The first permanent white settlement in Minnesota was not a part of this movement of population that came up the Mississippi. The real beginning of settlement came from the Red River valley where Lord Selkirk had attempted to establish a colony of Scotch highlanders. In I 8 II he secured a grant from the Hudson Bay Company, and in 1812 he made an attempt at settlement. The Northwest Fur Company objected strenuously to this proposed colony and, when Lord Selkirk arrived in 1817 with about one hundred Swiss colonists, hostilities resulted between the companies, in which several colonists were massacred. As early as 1820 the Red River settlers sent to Prairie du Chien for seeds and thus commenced commercial relations with the settlements in the United States. In I82I Alexis Bailly took a drove of cattle to the Red River valley and on his return he was accompanied by five families who were disappointed at the prospects in the Pembia region across the line in Canada. These Swiss families were allowed to "squat" upon the lands belonging to the Fort Snelling military reservation, and this constituted the first real settle-

${ }^{12}$ Neill, "Fort Snelling from 1819 to 1840 ," in Mimnessta Historical Collections, 2:107.

"Williams, History of St. Paul and of Ramsey County, 173.

is "I have known steamboats to reach St. Paul as late as the 18 th or 20 th of November and get back safely to Galena, and to return by the 1st of April; but this is not usually the case." Sibley to Senator Foote, published in Minnesota Historical Collections, $1: 22$. 
ment in Minnesota. In 1823 other families came from the Red River valley, and by 1835 nearly five hundred persons had come. Some of these Swiss families remained as squatters on the military reserve, but most of them went on down the Mississippi, some of them going as far as Vevay, Indiana. ${ }^{16}$

In 1838 , the settlers were forced off the reservation lands west of the Mississippi. They crossed the river and erected cabins on land belonging to the military reserve on the east side of the Mississippi. The military authorities had much trouble with whiskey sellers who sold liquor to the soldiers at Fort Snelling and finally, in I839, the United States Marshal from Wisconsin Territory was ordered to remove all squatters from the lands within the reserve on the east side of the river. The settlers were given all winter to prepare, but they made no move to vacate the lands. On May 6, I840, the troops from Fort Snelling were called out and the settlers were driven off and their cabins destroyed. The squatters went no farther than was necessary and settled down again about the whiskey shanty of Peter Parant, thus making the beginning of the settlement called "Pig's Eye," later "St. Paul's Landing," and finally St. Paul, the future capital of Minnesota. ${ }^{17}$

The town of St. Paul was laid out in 1847 , a year before the land was brought into the market. A Land Claim Association, an institution used in most of the States in the Middle West during this period, was used to secure title to the settlers. ${ }^{18}$

${ }^{16}$ Neill, "Fort Snelling from 1819 to $1840, "$ in Minnesota Historical Collections, 2:127.
${ }^{17}$ Ibid, 142 .

Is "The moste

people present, was on the time during this sale (at St. Croix), at which there were a great many offered for sale. The good day and the day before that on which the town-site of Saint Paul was infested with a hungry seot people of this community were very fearful that the sale would be ready with their gold to ju speculators, as has too often happened at land sales in the West, settler. To guard against Sibley should bid in the this emergency, it was understood beforehand that the Hon. H. H. understand English sufficiently to of Saint Paul and the claims of such Canadians as did not large and well-armed force, sale. Their fears, however, composed principally of Canadian Frenchmen, were present at the without molestation." From " wot realized, and they were permitted to purchase their lands St. Paul and of Ramsey County, 184 . .
Another who was present," quoted in Williams, History of

them in and everything passed of the land sales, said: "When our pieces were called, we bid 
A tract of ninety acres was secured at the first land sales, which were held at St. Croix in 1848 , and the town plat was legally entered in $1849 .{ }^{19}$

The settlement at Pembina in the Red River valley also grew out of the settlement of the Selkirk colony. When that colony was first established, the boundary line between the United States and the British possessions was not definitely fixed west of the Lake of the Woods. In 1818 , it was agreed that the $49^{\text {th }}$ degree of latitude should be the boundary, and from 1823 when the line was located the British companies tried to keep the settlement on the Canadian side. ${ }^{20}$ The British fur companies continued to draw large amounts of furs from the region south of the line even as late as 1849 when Minnesota Territory was organized. ${ }^{21}$ A settlement, called Pembina, grew up on the American side and by 1849 had a population of 637 , mostly half-breeds connected with the fur trade.

The trade which grew up between the Red River settlements and St. Paul was carried on in what were known as the Red River ox-carts, rude two-wheeled vehicles made entirely of wood. By 1844 regular trains of these carts began to reach the little settlement of St. Paul, bringing buffalo tongues, buffalo robes, furs, and pemmican, and taking back general supplies.

fellow attempted to put his finger in our pie, he would have heard something drop." Larpentuer, "Recollections of St. Paul, $1843-1898, "$ in Minnesota Historical Collections, 9:378.

Sibley described his part in the land sales in the following words: "I was selected by the actual settiers to bid off portions of the land for them, and, when the hour for business had arrived, my seat was invariably surrounded by a number of men with huge bludgeons. What was meant by the proceedings I could, of course, only surmise, but I would not have envied the fate of the individual who would have ventured to bid against me." Sibley, "Reminiscences of the Early Days in Minnesota," in Minnesota Historical Collections, 3:244.

13 Williams, History of St. Paul and of Ramsey County, $17 \mathrm{r}$.

${ }^{20}$ In a letter to the Chronicle and Register, in 1849 , John Pope stated that the half-breeds "were actually forced by the Hudson Bay Company to remove to the British side of the line." Chronicle and Register, Oct. $13,1849$.

"1 The Hudson Bay Company opposed the trading with the Indians by the settlers at Pembina. "Their minions do not stop to search for the 49 th parallel when on the track of some poor trader who has bought of an Indian a fox or a lynx skin. No difference to them whether he is on British or American ground. Thanks to Mr. Kittson, the 'Yankee Trader,' as the Bay Company's agents call him, he has fully established his claims at Pembina, and the rich packages of furs brought in this season abundantly proves that he is fully able to maintain it. We are inclined to think that 'John Bull caught a tartar' when he undertook to bully Kittson." Minnesota Register, Aug. 11, 1849 . 
The route usually followed by these carts led up the Red River valley, on the Dakota side of the river, crossed between Lake Traverse and Big Stone Lake, and thence by way of Traverse des Sioux to St. Paul. After 1844 a more direct trail was cut through farther north, and this route was followed later by the Northern Pacific railroad. ${ }^{22}$

Very little government existed before 1840 in the region which became Minnesota. In that year, the peninsula between the St. Croix and the Mississippi rivers was included in the newly organized county of St. Croix, Wisconsin Territory. In the region west of the Mississippi, Sibley was for many years the only representative of the law, having received a commission as Justice of the Peace in Clayton county, Iowa Territory, in 1838 . "It was my fortune," Sibley wrote, "to be the first to introduce the machinery of the law into what our legal brethern would have termed a benighted region, having received a commission as Justice of the Peace from the Governor of Iowa Territory, for the county of Clayton. This county was an empire in itself in extent, reaching from a line some twenty miles below Prairie du Chien on the west of the 'Father of Waters' to Pembina, and across to the Missouri river. As I was the only magistrate in this region and the county seat was some three hundred miles distant, I had matters pretty much under my own control, there being little chance of an appeal from my decisions. In fact, some of the simple-minded people around me firmly believed that I had the power of life and death."

"Robinson, Eronomic History of Asriculture in Minnesota, 32.

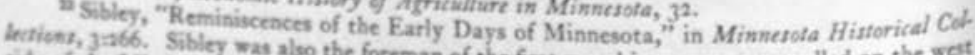
ide of the Ministipgi in also the foreman of the first grand jury ever empanelled on the west Early Duys of Minnein what is now the State of Minnesota. Sibley, "Reminiscences of the Jartice of the Peace, date, in Minmesota Hintorical Collections, $3: 267$. "Sibley's commissions as

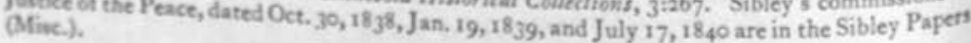




\section{CHAPTER IV}

\section{THE MAKING OF A NEW TERRITORY}

Since most of our territories were organized in much the same way the story of the organization of Minnesota may be taken as a type. The first movement in Congress for the organization of a territory west of Wisconsin was during the session of 1846-47 while the enabling act for Wisconsin was under consideration when a bill for that purpose was introduced in the House by Morgan L. Martin, the delegate from Wisconsin Territory. The Committee on Territories reported the bill favorably, but with the name "Itasca" which Stephen A. Douglas, the chairman of the committee, was said to favor. When the bill came up in the House other names were suggested. Houston, of Delaware, proposed the name "Washington"; Thompson of Mississippi, suggested "Jackson"; Winthrop, of Massachusetts, thought "Chippewa" most suitable. Martin moved to substitute "Minnesota" for "Itasca," as had originally been provided in his bill, and this motion prevailed. The bill with amendments passed the House, but was not passed by the Senate. ${ }^{1}$

Another effort was made during the next session of Congress when Douglas, who had recently been elected to the Senate, introduced a bill into the Senate. It received some consideration by that body, but Congress adjourned on August 14, 1848, without passing it. ${ }^{2}$ In the meantime, on May 29 , the State of Wisconsin had been admitted into the Union with its western boundary at the St. Croix river. This situation apparently left the people who lived between the St. Croix and the Mississippi without political organization. They had been included

The chief obiections to the kill is the Senste were the scanty population, the fact that no lands had been surveyed and sold in the region, and the fact that the people there had sot requested such organization. Corpranienal Glade, ag Cong. a Sess. 7r, 441, 445.

${ }^{2}$ Centrumienal Glale, 30 Cong. I Sess. 136, 6g6, $77^{2}$. 
in the Territory of Wisconsin, whose boundary had extended to the Mississippi, but they were not included in the new State.

While the bill for the admission of Wisconsin was under consideration this matter of boundaries had called forth lively discussions, both in Congress and in the then Territory of Wisconsin. Several lines had been proposed as the northwestern boundary of the new State. In order of size which they would give, the lines most seriously considered were as follows: (a) a line drawn due west from Lake Superior to the Mississippi river; (b) the Rum river line; (c) the St. Croix river line; (d) a line drawn from Rush river of Lake Pepin to Lake Superior; (e) the Menominee river and the Brule river. ${ }^{3}$ The first two lines above mentioned met with objections largely because of the size they would give $\mathrm{W}$ isconsin and also because there would not be enough settled territory left for the immediate organization of Minnesota Territory. The chief difficulty, after discarding the first mentioned line, was as to what should be done with the St. Croix valley. The second constitutional convention of Wisconsin wanted to include this entire region in the new State and asked that the boundary be placed at the Rum River. Most of the people living in the St. Croix valley, together with the few who lived west of the Mississippi, where there was no political organization at all after the admission of Iowa, favored the Rush river line in order to keep the entire St. Croix valley under the same jurisdiction and so it would be in the proposed new territory of Minnesota. Those people

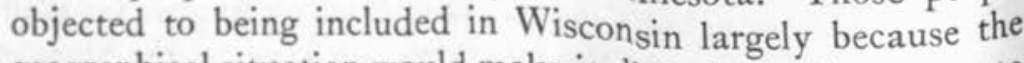
geographical situation would make it difficult for them to go to Madison, the State capital. Distance was not the only difficulty these people would encounter, however, as extensive pine barrens and swamps were between the two places. These were not and would not for many years be inhabited or have roads constructed through them. If, on the other hand, the

\footnotetext{
"The first four lines are mentioned in Sibley, "Reminiscences Historical and Personal," in Minnesota Historical Collections, $\mathrm{I}: 483$. The fifth line as proposed by Smith, of Illinois, on May 9, 1848. Congressional Globe, 30 Cong. I Sess. 742.
} 
entire St. Croix valley was left out of Wisconsin and included in Minnesota, water transportation and communication to the capital of the new territory, Stillwater, St. Paul, Mendota, or where ever it might be located, would be comparatively easy. ${ }^{4}$ The St. Croix line had been proposed by Congress and was finally accepted. It was a compromise line and has since remained the northwestern boundary of Wisconsin. ${ }^{5}$

The admission of Wisconsin and the failure of Congress to pass the bill for the organization of Minnesota Territory caused the people living in the residuum of Wisconsin Territory to assert what they considered their rights to political organization and to representation in Congress. The first meeting for the agitation of the subject was held in St. Paul in July, I848, even before Congress had adjourned. The meeting was organized by the election of a chairman and secretary, some speeches were made, and resolutions were adopted in favor of a convention of the people of the region. ${ }^{6}$

The next step was the meeting at Stillwater on August 4, 1848 , attended by citizens from that place and by some from St. Paul and the region west of the Mississippi, who were on their way to the land sales at St. Croix, Wisconsin. The meeting seems to have been an informal gathering, and about all that was done was to issue the following call for another meeting at Stillwater: "We, the undersigned, citizens of Minnesota Territory, impressed with the necessity of taking measures to secure an early Territorial organization, and that these measures should be taken by the people with unity of action, respectfully recommend that the people of the several settle-

"Congressional Globe, 30 Cong. 1 Sess. 742-743. Sibley favored the Rush river line and was active in defeating the Rum river line. Sibley, "Reminiscences Historical and Personal," in Minnesota Historical Collections, $1: 483$. A memorial signed by 346 citizens, including Sibley, in relation to the Rum river line is in Senate Miscellaneous Documents, No. 93, 30 Cong. I Sess.

${ }^{3}$ This did not, however, end the agitation on the part of those settlers who lived east of the St. Croix river and who were included in Wisconsin. Efforts were made even after the organization of Minnesota Territory to have the boundary changed so as to transfer that part of the St. Croix valley to Minnesota Territory. Minnesota Pioneer, Feb. 13, 1850. Also Minnesota Chronicle, Feb. 15, 1850.

"Williams, History of St. Paul and of Ramsey County, 181. Also Sibley, "Reminiscences Historical and Personal," in Minnesota Historical Collections, $1: 484$. 
ments in the proposed Territory appoint delegates to meet in convention at Stillwater, on the 26th day of August next, to adopt the necessary steps for that purpose."7

Pursuant to this call, there assembled at the appointed time the meeting which has since been known in Minnesota as the "Stillwater Convention." Joseph R. Brown took the leading part in the work of the convention. Morton S. Wilkinson, of Stillwater, was chosen temporary president and David Lambert, of St. Paul, temporary secretary. The committee on permanent organization reported the name of Samuel Burkleo for president, Robert Kennedy and Joshua L. Taylor for vice presidents, and William Holcombe and David Lambert for secretaries. A committee of seven, composed of Joseph R. Brown, Calvin Leach, H. H. Sibley, Socrates Nelson, M. S. Wilkinson, Henry Jackson, and H. L. Moss, was appointed to draft two memorials, one to Congress and one to President Polk, asking for the immediate organization of Minnesota Territory. These memorials recited that the people residing in the region had formerly been subject to the laws of Iowa and Wisconsin; that a judicial circuit had been established and courts of record held in the region in question; that there was a population of nearly five thousand persons who were engaged in various industrial pursuits; that with the admission of Wisconsin they were "left without officers to administer and execute the laws; that, having once enjoyed the rights and privileges of citizens of a Territory of the United States, they were, without any fault or blame of their own, virtually disfranchised." The memorial also stated that there were no securities of life and property "but those which exist by mutual understanding"; that all proceedings in criminal cases had been suspended, and all the operations of business had been embarrassed. While the citizens already in Minnesota were said to "It is important to notice that in this call the members of this convention spoke of them-
selves as "citizens of Minnesota Territory." This call was signed by eighteen citizens, including
Sibley.
'The proceedings of this meeting are published in Minnesota Historical Collections, $1: 55-56$. 
be law-abiding,' nevertheless the situation was fraught with evils and dangers. "Its continuance," they said, "will tend to prevent the immigration of the more valuable class of citizens of the United States, while it will open the door of invitation and allurement to the lawless and desperate. It will foster dishonest and disorderly principles and action among their citizens, and, if suffered to exist for a long period, will bring ruin upon a prosperous and fertile region." The memorial was signed by all of the sixty-one members.

The convention also approved a set of resolutions, the preamble of which made it perfectly clear that the inhabitants of the residuum of Wisconsin Territory believed that the territorial government ceased with the admission of Wisconsin and that the failure of Congress to organize a separate territorial government over them, which they could explain only on the ground that Congress was unacquainted with conditions, deprived them of rights and privileges which were guaranteed to them by the Ordinance of 1787 . It was also resolved that a "delegate" should be appointed "to visit Washington" during the next session of Congress "there to represent the interests of the proposed Territory, and to urge the immediate organization of the same." It was resolved further that a committee of six should be appointed, three members residing on the St. Croix and three on the Mississippi, to "collect information relative to the amount of business transacted and capital employed within the limits of Minnesota Territory, and forward such information as soon as may be, to our Delegate." Finally, it was resolved "That there shall be a committee of seven appointed by the president of this Convention to act as a central committee, whose duty it shall be to correspond with our Delegate at Washington, and to adopt all other proper means to forward the objects of this Convention."

The convention then proceeded to the election of a delegate. "On the first ballot," reads the minutes, "Mr. H. H. Sibley,

\footnotetext{
'Minnesota was fortunate in this respect as the settlement of California which was taking place at the same time drew the most lawless characters away from the upper Mississippi country.
} 
having received a majority of all the votes cast, was, on motion of Joseph R. Brown, declared unanimously elected by the Convention." Sibley was given a certificate of election signed by the President, the Vice President, and the Secretaries of the convention..$^{10}$

It is evident from the proceedings of this convention that these people regarded themselves as being without territorial organization. The "delegate" which they had in mind was more of an "agent" than a delegate in the sense that a regular territory was entitled to be represented by such an officer. Their "delegate" was merely "to visit Washington" to lobby for the organization of the territory, and it was expected that he would defray his own expenses. ${ }^{11}$

This meeting illustrates a significant fact in the history of the West. These people, after Congress failed to establish any political jurisdiction over them, might have had any kind of government of their own making, or no government at all. Men on the frontier under these circumstances have chosen to have an orderly and properly constituted authority over them. When such did not exist, they themselves maintained order. It is remarkable that business could be carried on at all in a region where there was no legal provision for government, as was true west of the Mississippi after the admission of Iowa and was true in the residuum of Wisconsin Territory after the admission of Wisconsin and before the organization of Minnesota Territory.

Soon after the Stillwater Convention, the theory of having Minnesota East ${ }^{12}$ still called Wisconsin Territory and continuing the territorial organization there came into existence. It is uncertain as to who originated this project, but on August 22, 1848, Secretary John Catlin, of the Territory of Wisconsin, wrote from Madison to William Holcombe, of Stillwater, pro-

${ }^{10}$ This certificate of election is to be found among the Sibley Papers.

Minnesota Territory," in Minnest. Paul and of Ramsey County, 183. Also Moss, "Early Days in ${ }^{12}$ Minnesota East is an expression to Historical Collections, $8: 78$.

Mississippi and had been in Wisconsin to describe that part of Minnesota which lay east of the 
posing the continuance of the organization. ${ }^{13}$ Catlin also sent along with his letter a copy of an opinion by Secretary of State Buchanan to the effect that the laws of Wisconsin Territory "were still in force over the territory not embraced within the limits of the State." "It cannot well be supposed," Buchanan wrote, "that Congress, by admitting the State of Wisconsin into the Union, intended to deprive the citizens of the United States, beyond its limits, of the protection of existing laws; and there is nothing in their legislation from which any such inference can be drawn. The difficult question is, what officers still remain to carry those laws into execution. It is clear to my mind that all the local officers residing in counties without the State line, such as judges of probate, sheriffs, justices of the peace, and constables, may exercise their appropriate functions as heretofore. Whether the general officers, such as Governor, Secretary, and Judges, appointed for the whole of the former Territory, are authorized to perform their duties within what remains of it, presents a question of great difficulty, on which I express no opinion. Whatever may be the correct decision of this question, immediate legislation is required; because it is very certain that Congress will never consent to maintain the machinery provided for the government of the entire Territory, merely for the purpose of governing the twenty-five hundred or three thousand inhabitants who reside beyond the limits of the State."14

The point on which Buchanan would give no opinion was precisely the course that Catlin proposed to pursue. He reasoned that if the laws of Wisconsin Territory were still in force, it was "equally clear that the officers necessary to carry out those laws are still in office." This would include the Secretary and the Delegate in Congress. In regard to the delegate, Catlin cited a precedent in the fact that "after the organization of the State of Michigan but before her admission, General

\footnotetext{
${ }^{18}$ This letter of Catlin's is published in Minnesota Historical Collections, 1:53-54, where it is incorrectly stated that the letter was read to the Stillwater meeting of August 4,1848 .

"Buchanan's opinion is published in Minnesota Historical Collections, 1:54-56.
} 
George W. Jones was elected by the Territory of Michigan, (now the State of Wisconsin) and was allowed to take his seat." "It is my opinion," Catlin continued, "that if your people were to elect a delegate this fall, he would be allowed to take his seat in December, and then a government might be fully organized; and unless a delegate is elected and sent on, I do not believe a government will be organized for several years. If Mr. Tweedy ${ }^{15}$ were to resign, (and he would if requested), I do not see anything to prevent my issuing a proclamation for an election to fill the vacancy, as the acting Governor; but I should not like to do so unless the people would act under it and hold the election. If a delegate were elected by color of law, Congress would never inquire into the legality of the election. It is the opinion of most all this way that the government of the Territory of Wisconsin still continues, although it is nearly inoperative, for want of a court and legislature." 16

This scheme was actually carried through. Tweedy resigned his office as delegate on September I8, I 848 . Since the Governor of Wisconsin Territory, Henry M. Dodge, had been elected to the Senate from Wisconsin, Secretary Catlin, on the theory that the election of Dodge to the Senate vacated the office of Governor, came to the residuum of Wisconsin Territory as acting Governor and issued a proclamation on October 9, calling an election for October $3 \circ$, for the purpose of electing a delegate to Congress from Wisconsin Territory.

In the campaign which followed, Sibley and Henry M. Rice, both of Mendota, were the only candidates and neither seems to have made much effort to be elected, although the friends of

\footnotetext{
Is Tweedy was the delegate from Wisconsin Territory at the time of the admission of the State and lived in the region embraced within the State.

28 Friends of Sibley living in Wisconsin wrote to him giving the information that Catlin would call an election and urging him to establish his residence in Wisconsin Territory and be eligible as a candidate for delegate. D. G. Fenton to Sibley, Sept. 4, 1848; also J. D. Doty to
Sibley, Sept. 4, 1848.
} 
both carried on an active and spirited campaign. ${ }^{17}$ In the latter part of September a report was circulated at Stillwater that Sibley was willing to withdraw in favor of a St. Croix candidate, if one was placed in the field, and if Rice became a candidate. Friends of Sibley who lived at Stillwater wrote to him and urged that he not withdraw. The chief interest which the citizens of Stillwater had in a candidate from that section of the territory seemed to have been that they were interested in the removal of the Land Office from St. Croix, Wisconsin, to Stillwater, and believed that a delegate who lived there would work more zealously to that end than either Sibley or Rice, both of whom lived on the Mississippi. ${ }^{18}$

In the early part of the campaign the sentiment was decided in favor of Sibley, but in the last few weeks before the election Rice gained considerable strength on the St. Croix, evidently due to certain promises that were made by his friends and certain reports that were circulated regarding Sibley. Sibley's friends distrusted Rice and believed that he was using, or would use, underhanded methods to gain the election. Some men actually favored Rice because they believed that he would use methods in securing the organization of Minnesota that Sibley would not use. ${ }^{19}$ As long as the end was legitimate, some frontiersmen were not inclined to be too particular as to the means employed to secure the end, provided it had, as Catlin said, "the color of law."

An incident came up during the latter part of October which shows the attitude and methods used by men on the frontier to secure what they regarded as their rights. Catlin was very anxious to have a large vote polled, believing that it would operate to a large extent in promoting the organization of

\footnotetext{
${ }^{17}$ Neither candidate was a resident of Wisconsin Territory at the time of the election. They were acting on the theory that it was not necessary for the delegate, as for Governor and other officers, to reside in the territory. Much will be heard of Rice later on. He was a fur trader and had considerable influence with the Winnebago Indians. During the summer of 1848 , he was helping remove these Indians to their new reservation near Crow Wing. This explains why he was not at Stillwater for the Convention and why he did not give more time to the canvass for delegate.

${ }^{13}$ Potts to Sibley, Sept. 14,1848 .
} 
Minnesota Territory, thereby seemingly justifying himself for the part he was playing in the residuum of Wisconsin Territory. He suggested to friends of the two candidates the expediency "of relaxing the challenges so as to admit of a full vote of all who would be entitled to suffrage if the Territory was organized." This, of course, proposed to let the settlers who lived west of the Mississippi, and therefore outside of Wisconsin Territory, have a vote in the election of a delegate from the residuum of that territory. This would admit some French Canadians who were favorable to Sibley and the settlers at Crow Wing who were favorable to Rice. It was probably thought that if they went west of the Mississippi for candidates they might as well go to the same region for voters, especially since they were using the name of Wisconsin Territory only as a means of securing the organization of Minnesota. Catlin's proposal was made known to Sibley through David Lambert, of St. Paul. Sibley objected to this practice and gave several reasons for doing so. In the first place, he said that Congress would proably scrutinize more strictly than usual the claims of the person elected as delegate when he presented himself for admission to the House, and that any irregularity in the election would decrease the probability of his admission. In the second place, if Rice was defeated he might choose to contest the election on the ground of illegality by the admission of these votes. In the third place, and this was the reason that Rice favored the proposal, Rice had "either in his employ or under his immediate influence a large number of men who are not legal voters, and who would to a man cast their votes for him and thus neutralize those of the old settlers." Sibley also pointed out that many of the French could not vote anyway under the proposal, since they had not declared their intention

\footnotetext{
10 Among other things it was reported that "the people of St. Paul had everything cut a nd dried" to elect Sibley and defeat Stillwater in their efforts to get the Land Office. Also it was said that Sibley had "packed" the Stillwater Convention by bringing over some French Canadians to vote for him for delegate. Jacob Fisher to Sibley, Sept. 24, 1848. Also Moss to Sibley, Oct. 10 and Oct. 20, 1848; and Potts to Sibley, Oct. 3, 1848.
} 
of becoming citizens, and that the proposition would operate chiefly in favor of Rice. Sibley maintained that it was not necessary to resort to illegal means to secure the organization of Minnesota, since the delegate could easily explain that there were more people in the region than was indicated by the election returns. He therefore insisted that the election laws be followed to the letter. ${ }^{20}$ In spite of his attitude, however, the two election precincts were established. He then protested to Catlin who skillfully shifted the responsibility to the county commissioners of St. Croix county who established the precincts. ${ }^{21}$

The election was held on October 30,1848 , without any serious disturbance or disorder, but with circumstances which suggest irregularities on the part of some of Rice's friends. ${ }^{22}$ Sibley was elected and received from Catlin a certificate of election. He had, therefore, a double election, one by the Stillwater Convention as "delegate" from the proposed Territory of Minnesota and one by virtue of what was claimed to be a legal election in Wisconsin Territory, as a regular territorial delegate.

Sibley left for Washington before the news of the presidential election was received in Minnesota, and when his constituents heard that Taylor had been elected President they feared that the desire to get the first chance at the patronage in a new territory would cause the Whig members of the House not to favor the immediate organization of Minnesota. J. S. Norris wrote a very prophetic letter to Sibley on December $3 \mathrm{I}$, 1848 , in regard to the passage of the Minnesota bill. "Some doubts are entertained here," he wrote, "with regard to our getting an organization this session as it is thought that the Whig administration will prefer making the original appointments to having Democrats in office or making immediate

\footnotetext{
"David Lambert to Sibley, Oct. $\mathrm{x}, 1848$. Also Henry Jackson to Sibley, Oct. $14,1848$. A copy of Sibley's reply is in the Sibley Papers under date of Oct. 12, 1848.

2 Moss to Sibley, Oct. 20, 1848. Also Catlin to Sibley, Oct. 27, 1848.

z Instances of irregularity are mentioned in a letter from William Duger to W. H. Forbes, Oet. 31,1848 , in Sibley Papers.
} 
removals. But if this is the only difficulty it seems to me it can be avoided by the passage of the bill during the last hours of the session for I think we had better have Whig officers than no organization at all."

Some of Sibley's influential friends assisted him by writing to members of Congress in behalf of Minnesota. The most distinguished of these friends was Lewis Cass, the recent Democratic candidate for President against Taylor. While Sibley was in Detroit on his way to Washington, Cass gave him letters of introduction to some of the leading Democrats in Congress. John Catlin, who, the election of a delegate being accomplished, had again taken up his residence at Madison, Wisconsin, wrote to several members of Congress. He also furnished Sibley with arguments in favor of the immediate organization of Minnesota. "The strong arguments in the case," he wrote to Sibley on November 2I, I848, "are the number of inhabitants, the amount of business, the fact that the government has sold public lands and invited the people to settle there, and the fact that a government has once been extended over them. If the government will not allow a State to repudiate or secede, can it nullify or repudiate a State or Territory and to repeal the law establishing a government is the same thing. If a State cannot secede without the consent of the Union, the Government cannot throw off a people without their consent when a government has once been estab-
lished." Catlin thought that the question needed "only to beught that the question was so plain that it On his way to understood to be correctly decided." congressmen whe national capital, Sibley fell in with some opening of the session on their way to Washington for the regarding the session and he had conversations with them mentioned especially much interest in ask to be admitted mission, but who advised him not to Wentworth believed as a delegate from Wisconsin Territory. tempted it and that Sibley would fail in this if he atthat such failure would prejudice Congress 
against the organization of Minnesota. He believed that Sibley could do more for Minnesota as a lobby member than as a delegate from Wisconsin Territory. Sibley arrived in Washington two days before the opening of Congress and was soon convinced that his admission to a seat was extremely uncertain, if not improbable. ${ }^{23}$

It was a momentous period in American history and one not very favorable to the organization of a territory when Sibley sent in his credentials as a delegate. The Mexican War had just been fought, bringing under the jurisdiction of the United States the immense cession of territory in the west and southwest. It would be necessary before long for Congress to make some arrangement for territorial organization in that region. The questions which finally led to the Compromise of 1850 were taking shape in the minds of members of Congress. In that same year, 1848 , the Free Soil Party had come into existence to fight against the further extension of slavery and, while it did not carry any States in the election, it did take enough votes from Cass to give New York and the election to Taylor. Congress was preparing itself for the great struggle that was coming. These were the conditions when Sibley sought admission and began his fight for the organization of Minnesota.

Sibley's credentials were presented on the first day of the session by James Wilson, of New Hampshire, in whose hands they were placed, as Sibley said, because "he had formerly lived in Iowa and might be supposed to be better informed as to our situation and geographical position, than any other member." 24 Wilson rose to a privileged question and, in presenting

\footnotetext{
2 Sibley, First Address to the People of Minnesota Territory, March 10, 1849. Published in pamphlet form in Washington, copies of which are in the library of the Minnesota Historical Society. It is also published in West, Sibley, appendix, 442.

${ }^{2}$ How little the frontier region of the upper Mississippi valley was known to even wellinformed men of the time is shown by the speeches of some members of Congress while the Minnesota bill was under consideration. Root, of Ohio, especially denounced as farcical and absurd the formation of a territory in such a region as Minnesota. "When God's footstool is so densely populated," he said, "that each human being can only occupy two feet square, then, and not till then, will white men go to that hyperborean region of the Northwest, fit only to be the home of savages and wild beasts." Congressional Globe, 30 . Cong. 2 Sess.
} 
the credentials, explained the circumstances under which Sibley had been elected, and asked that he be admitted without objection. The matter was not to be so easily disposed of, however, since Cobb, of Georgia, thought the matter should be investigated by a committee. ${ }^{25}$ Wilson thereupon submitted the papers and moved that they be referred to the Committee on Elections. This motion was agreed to and the question of Sibley's admission was not settled for six weeks. During this time Sibley was, through courtesy, permitted to occupy a seat in the House but he was, as he afterwards explained, "little more than a lobby member."

At the time that his credentials were presented there was some curiosity manifested by the members to see what kind of a person had been elected to represent the distant and wild territory claiming representation in Congress. "I was told," Sibley later wrote, "that there was some disappointment felt when I made my appearance, for it was expected that the delegate from this remote region would make his debut, if not in full Indian costume, at least with some peculiarities of dress and manners, characteristic of the rude and semi-civilized people who had sent him to the capital." ${ }_{26}$ No doubt Sibley's stately bearing and dignified appearance, his high character and attainments, had much to do with the final action of the House in admitting him to a seat.

The Committee on Elections took up the consideration of Sibley's credentials and his right to a seat in the House. Boyden, of North Carolina, was the principal opponent. He made a "long and labored argument" against Sibley's right to a seat and "ridiculed the pretentions that a territorial organization still existed in the country north and west of Wisconsin." On December 22, Sibley delivered a speech before the committee in support of his claims. He stated that no question had been or could be raised with regard to the legality of his election.

\footnotetext{
"Ibid, p. 2.

"Sibley, " lections, 3:270.

Minnesota Historical Col-
} 
The only question involved was whether "the residuum of Wisconsin Territory, after the admission of the State, remained in possession of the same rights and immunities which were secured to the people of the whole Territory by the organic law." The failure of Congress to repeal the organic act of Wisconsin Territory, Sibley argued, made it clear that the "residuum remains under the full operation of the same organic law." Good faith on the part of the United States, he said, demanded that the people whom he had come to represent should be given proper representation. "The Government of the United States, when it invited its citizens to emigrate to the Territory of Wisconsin by the formation of a temporary government, must have intended to act in good faith towards them, by continuing over them the provisions of the organic law. Sixteen thousand acres of land had been purchased, for the most part by bona fide settlers, the proceeds of which have gone into your treasury. Taxed equally with other inhabitants of the Union for the support of the General Government, they are certainly entitled to equal privileges." The people whom he represented were not asking to have rights given them; they had already enjoyed these rights and privileges. They had participated in the election of a delegate, they had a full county organization (St. Croix county), and had formed a part of a judicial circuit. If laws were in force among them it was because of the organic law of Wisconsin Territory, the same act that entitled them to a delegate in Congress. In closing his speech, Sibley paid a high tribute to the pioneers of the Northwest and made an earnest appeal for a fair decision. "The people have emigrated to the remote region they now inhabit under many disadvantages. They have not been attracted thither by the glitter of inexhaustible gold mines, but with the spirit which has actuated all our pioneers of civilization. They have gone there to labor with the axe, the anvil, and the plow. They have elected a delegate, with the full assurance that they had a right to do so, and he presents himself here for admission. Sir, was this a question in which the 
consequences would be confined to me personally, the honorable members of this House would not find me here, day after day, wearying their patience by my appeals and explanations. But believing as I do, before God, that my case and the question whether there is any law in the Territory of Wisconsin are intimately and indissolubly blended together, I trust that the House of Representatives will, by its decision of the claim before it, establish the principle, which shall be as a land mark in all coming time, that citizens of this mighty Republic, upon whom the rights and immunities of a civil government have once been bestowed by an act of Congress, shall not be deprived of these without fault or agency of their own, unless under circumstances of grave and imperious necessity, involving the safety and well-being of the whole country." ${ }_{27}$ The Committee on Elections brought in two reports, the majority report being favorable to Sibley and based upon his arguments. ${ }^{28}$

On January 2, 1849, Thompson, of Indiana, from the Committee on Elections, reported to the House with the resolution: "Resolved, that Henry Hastings Sibley be admitted to a seat on the floor of the House of Representatives as a Delegate from the Territory of Wisconsin." The report and resolution were laid on the table and ordered to be printed. They were taken up again on January $1_{5}$, and Sibley was seated by a vote of 124 to $62 .{ }^{29}$ An analysis of this vote reveals some interesting facts. Of the $I_{2} 4$ voting in the affirmative 65 were Democrats and 59 were Whigs. Of the 62 voting in the negative, 27 were Democrats and 35 Whigs. The resolution was carried, thereelected delegate, not as a member parties. Sibley had been as the most influential man in the reg any political party, but him shows that politics was not region, and the vote on seating decision of the House. Of not the controlling factor in the 57 were from the East, Of the 124 voting in the affimative, ${ }^{n} \mathrm{West}_{\text {est }}$ siug 35 were Whigs and 22 Demo-

"2 West, Sibley, appendix, 435-441.

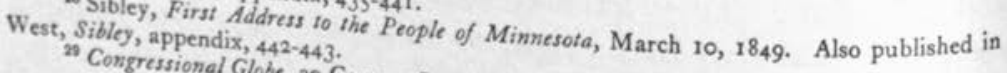
${ }^{20}$ Congressional Globe, 30 Cong. 2 Sess. $137,259,260$. 
crats; 38 were from the West, of whom I 3 were Whigs and 25 Democrats; 29 were from the South, of whom II were Whigs and 18 Democrats. Of the 63 votes in the negative, 24 were from the East, of whom I9 were Whigs and 5 Democrats; 2 were from the West, one Whig and one Democrat; 3 were from the South, of whom 15 were Whigs and 21 Democrats. Grouped according to sections, therefore, the East voted 57 for and 24 against. The West voted 38 for and 2 against; the South voted 29 for and 36 against. This indicates that the South was not anxious to have a territory organized in the North and started on the way to statehood without a corresponding territory in the South, but the vote is not as large that way as might have been expected. ${ }^{30}$

It is interesting to note some of the individuals and how they voted on the question. Abraham Lincoln was present and voted in the affirmative; also Giddings, of Ohio, Tallmadge, of New York, Wentworth, of Illinois, and Wilmot, of Pennsylvania. On the other hand, Horace Greely, of New York, Andrew Johnson, of Tennessee, King, Toombs, and Cobb, all from Georgia, and Boyden, of North Carolina, were among those voting in the negative.

Although the House of Representatives had voted to seat Sibley as a delegate from Wisconsin Territory, it did not admit the continuance of the territorial organization. This was shown a few days after Sibley was seated when Mullin, of New York, who had opposed seating Sibley, in order to open the question for debate, as there had not been an opportunity before on account of the rule of the previous question, moved to add an amendment to the general appropriation bill for an appropriation of $\$ 10,500$ for the territorial officers of Wisconsin Territory, the same amount as was included for Oregon. Although this amendment was finally rejected it led to a lively debate, and the House was taunted with having admitted a delegate to

\footnotetext{
${ }^{20}$ In this analysis East means east of the Alleghanies and north of the Potomac; West means west of the Alleghanies and north of the Ohio; South means south of the Potomoc and Ohio rivers.
} 
represent a territory which in reality had no legal existence. ${ }^{31}$ This action of the House showed that there was a repudiation of the idea that there was still a Territory of Wisconsin, and indicated that the members who had voted to seat Sibley had been influenced by other considerations. This was partly due to the personal regard which many members had for Sibley and their willingness to help along the organization of Minnesota Territory. This action of Congress in refusing the appropriation brought disappointment to $\mathrm{C}$ atlin, the acting governor of Wisconsin Territory, who called the election for delegate. He wrote to Sibley in regard to the payment of his salary and Sibley brought it before the House but without success.

The great object to which Sibley now gave his attention was the passage of the bill for the organization of Minnesota Territory. On the first day of the session, immediately after roll call, Stephen A. Douglas gave notice that he would on the following day or at an early day ask leave to introduce bills to establish the territories of Minnesota, Nebraska, and New Mexico, and a bill for the admission of California as a State. ${ }^{32}$ When the bill was drawn up, Douglas sent it to Sibley, who was allowed to change certain provisions in order to meet the wishes in regard to the location principal change made by Sibley was Douglas, Mendota, Sibley's home town Sibley knew that it was the wish of town, was made the capital. that the capital should be at St. Paul. people in the territory mittee on Territories was called and Sibley discussed the question at some length before Douglas change." The Minnesota bill came up for debate on January I8,
1849. Butler, of South Carolina although he would probably not oppose its, although he stated that he assage, reminded the Senate

\footnotetext{
"1 Congreasional Globe, 30 Cong, 2 Sess. 295-297. Also Sibley, First Address to the People
of Minnetota Territory, March 10, 1849 .
" Congrestional Glose, 30 Cons.

n Ibid, 1. Also Sibley, Firng. 2 Sess. 295-297.

bill with corrections made in Sibiey's hand to the People of Minnesota Territory. A copy of the
} 
that the proposed territory included some 20,000 acres of land covered by the Ordinance of 1787 , which had provided that not more than five States should be formed out of the Northwest Territory. He considered this a violation of the Ordinance of 1787 , but he admitted that the Senate no longer had any control over the matter, and stated that he rose simply to remind the Senate of this situation. Westcott, of Florida, thought that the bill as originally drawn provided for a territorial judiciary which was entirely unnecessary, as the population would not exceed 7,000 at most. He thought that it would be better to leave the judiciary to be provided later when the population had considerably augmented. Douglas reminded him that the provision was the same as that contained in other territorial bills and that the committee had thought best to put Minnesota upon the same footing as other territories. On the following day, King, of Alabama, asked regarding the population of Minnesota and was informed by Douglas that it was probably between 8,000 and 10,000 , at least more than the usual number necessary for the establishment of a territorial government." This population, Douglas explained, was in compact settlements scattered throughout Minnesota and, while not adjoining each other, these were within the proper limits of the territory and in a position where laws could very well apply. Westcott informed King that he had had "a very interesting conversation with the delegate from Minnesota in relation to this very subject. ... This delegate has impressed upon my mind the great necessity of having a territorial government for Minnesota by a variety of reasons. Emigrants are crowding rapidly into the territory and the inhabitants are building mills of a very important character. They are absolutely making improvements on the rivers and preparing to

"Douglas stated the population to be about twice as large as it actually was. When the territorial census was taken in 1849 there were only 4,764 inhabitants, including some 317 soldiers and their families. As a matter of fact, Minnesota had the smallest population of any territory at the time of its organization. This is another illustration of the ignorance regarding frontier conditions. It is interesting to note how the population of Minnesota grows in each of the speeches during the debate on the bill. 
make a dam along the side of one of the larger streams. There is no law to affect the actions of individuals in this respect; and in fact ever since Wisconsin was admitted into the Union, there have been no laws of any description to regulate the affairs of the inhabitants. I am told that there are some forty lawyers practicing there, which is a favorable sign as to the resources and extent of settlement. I am fully satisfied of the necessity of immediate organization of a government over them." 35 Dodge, of Iowa, made a strong plea in favor of the immediate organization of Minnesota, and Butler, of South Carolina, stated that "if there are ten thousand inhabitants in that Territory, they certainly demand at least ordinary territorial government." This question of population was the chief objection raised in the Senate to the immediate organization of Minnesota, and the Senators seemed disposed to take the statement of Douglas as satisfactory on that point. Douglas assured the Senate also that the Minnesota bill did "not contain a single peculiar provision," and that it was drawn up as other territorial bills. The bill was then ordered to its passed. ${ }^{36}$ tead a third time by unanimous consent, and

The Minnesota bill 1849, when Smith bill came up in the House on February 8, tories, reported it of Indiana, from the Committee on Terribeing desirous it back with amendments. The committee, chairman to report anly action on the bill, had instructed the tion, in order to obviatendment to strike out the appropriaCommittee of the Whiate the necessity of referring it to the tained nothing with which Smith explained that the bill confamiliar and, since it hich the members of the House were not the House would put it already been printed, he hoped that speaker ruled, however, immediately upon its passage. The Senate had containeder, that, since the bill as it came from the

-

by interviews with the members of Congress. $298-99$. This illustrates Sibley's method of working

*Congressional Globe, 30 Cong. 
be necessary under the rules of the House for it to receive its first consideration in the Committee of the Whole on the state of the Union.

Sibley had the following letter printed and a copy placed on the desk of each congressman $:^{37}$

"House of Representatives,

Saturday February 17,1849 .

Sir: It is not probable that the bill for the organization of Minnesota Territory will be reached in the order of business before the committee of the whole. As a failure of this bill would be a most certain calamity to the people of that territory, I take the liberty to appeal to your kind feelings, in their behalf, to sustain me in a motion I shall make on Monday to suspend the rules, that the bill may be taken up and passed. It is not probable that any debate will take place upon it. I am, sir, very respectfully,

Your obediant servant,

H. H. Sibley."

The Minnesota bill was taken up again on February 22, and Sibley moved that the rules be suspended in order to enable him to submit a motion to discharge the Committee of the Whole from further consideration of the measure so as to bring it before the House. This motion was carried. Although he had been appealed to by several members not to do so, Sibley then moved the previous question. At this point Boyden, of North Carolina, rose to a point of order and claimed that a territorial delegate had no right to move the previous question. The Speaker decided the point against him and he appealed from the decision of the chair, but the House sustained the Speaker's ruling. The main question was finally put and was carried by a vote of 102 to 99 . Most of the amendments were agreed to without debate. The most important amendment, from the standpoint of Congressional debate, was the following: "This Act shall take effect from and after the roth day of March, I849." Kaufman, of Texas, a Democrat who had voted to seat Sibley, asked if the amendment was not offered palpably to give the appointment of territorial officers to Taylor instead of to Polk. The Speaker replied that he had no

${ }^{n 7}$ A copy of this letter is among the Sibley Papers.

${ }^{3}$ Congressional Globe, 30 Cong. 2 Sess., $485,5^{1 / 3}, 5^{81-85}$. 
information on the subject. The amendment was then agreed to without further debate, by a vote of IOI to 95 . On February 28, the Minnesota bill came up for passage. Sibley, expressing his sense of the importance of the bill and his unwillingness to detain the House with any remarks, moved the previous question and his motion was carried. The main question was then put and the bill was passed.

The bill as amended in the House was returned to the Senate and called forth a long debate between Whigs and Democrats over the "spoils of office." The Senate Committee on Territories had agreed to all amendments except the one providing that the act should take effect on March Io. Walker, of Wisconsin, although he was a Democrat, hoped that the bill would pass at once, since it was very important that something be done for Minnesota immediately. He admitted that the House may have been "unnecessarily careful in fixing the time" of its going into effect, but he hoped that the bill would not be delayed by sending it back to the House. Davis, of Massachusetts, a Whig, thought this amendment a rather trifling matter and hoped that the Senate would concur. Douglas explained that the purpose of the amendment was to keep Polk from making the appointments and he, for one, was unwilling that a Democratic Senate should "pass this vote of censure." The Whig party, Douglas said, was not even willing to wait until their administration in order to get the spoils. Already they were asking that the salaries of foreign ministers be doubled and they were trying to create new consulships. They were also trying to organize a new Home Department (Department of the Interior) with all its train of offices. Douglas wanted to see a test vote on the subject and called for the ayes and nays. Underwood, a Whig from Kentucky, took up the debate with much vigor. "Mr. Douglas," he said, "reads us a lecture on the desire for spoils," and he thought it very becoming of Democrats to start this discussion, now that "the cup is to be applied to their own lips." He thought there was great wisdom in putting the law into effect at a distant date and said that "at 
the last gasp of this antinomian administration, in which so much is yielded to good works, we should not harass the Executive by hunting up new offices for him to fill." Allen, a Democrat from Ohio, thought that the Whigs should be modest in commencing their career in power. "They will be," he said, "the first minority administration; they will not have a majority of the American people with them;... they are not altogether sure that there is such a thing as a living Whiggery." This discussion between Whigs and Democrats as to their relative merits and desires for the spoils of office fills several pages of the Congressional Globe. The final outcome of the matter was that the Senate voted, 30 to 18 , not to concur in the amendment. This was a strict party vote. ${ }^{39}$

It was necessary, therefore, for the bill to go back to the House and, as it was so near the end of the session, it was possible if not probable that it would yet fail of passage. Sibley's anxiety during these last days of the session may well be imagined. It was at this point that a plan of action was decided upon which was destined to bring success. The bill for the formation of the Interior Department had passed the House and its fate was yet to be decided in the Senate. The story of how this measure was linked with the Minnesota bill and both passed in the last hours of the session is best told in Sibley's own words. "It was while laboring under great apprehensions," he wrote, "lest the Minnesota bill should be defeated, that I chanced to find myself in the Senate. I expressed my fears to several of the democratic Senators, who were my personal friends, and they, to the member of five or six, authorized me to say to the Whig leaders in the House, that unless that body receded from its amendment, and thus permit Minnesota to be organized, they would cast their votes against the bill for the formation of the Interior Department. I hastened back to the House, called together several of the prominent Whig members, and informed them of the state of affairs. Satisfied that the

\footnotetext{
${ }^{20}$ Congressional Globe, 30 Cong. 2 Sess., 617, 635, 637, 681, 698.
} 
votes of the Senators I named would turn the whole scale for or against a measure they particularly desired should succeed, they went to work in the House, and produced so great a change in a short time, that a motion to recede from their amendment to the Senate bill was adopted the same evening, by a majority of some thirty or forty, and into our infant territory was breathed the breath of life." 40 It was too late in the session to include an item in the general appropriation bill for an appropriation to carry the Minnesota Act into effect, and this was accomplished by means of a rider to a bill for the relief of James Norris, a citizen of the Northwest, whose claim was then pending in Congress.

Sibley's efforts to gain a territorial organization for his constituents were, therefore, rewarded with success. It had been his great purpose in going to Washington, and he had worked early and late for its accomplishment. Considering the state of feelings over slavery that were then crystallizing for the great debates of the following session, it was no easy matter to get the organization of a territory anywhere in the country." Sibley attributed much of his success to the fact that he had not been elected by any particular political party and that he had, therefore, been able to work with the leaders of both parties in Congress.

The news of the passage of the Minnesota bill reached St. Paul on April 9, 1849. The following account of the reception of the news was published in the Minnesota Pioneer of April 29: "Monday, the ninth of April had been a pleasant day. Towards evening the clouds gathered, and about dark commenced a

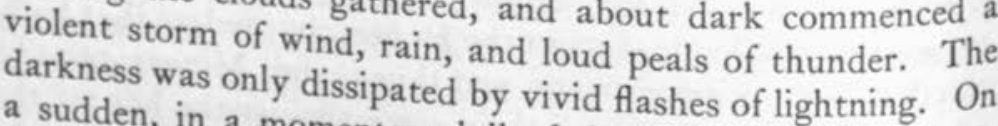
a sudden, in a momentary lull of the wind, the silence was "Sibley, "Address before the Old Settlers' Association of Minnesota," in Minnesota His-
torical Collections, $1: 62$. "Speaking, i:62.

reviewing Sibley's career, said. "It in this undertaking the Chicago Times, Jan. 30, 1886, in could have attained the same "It is scarcely possible that any other man in the Northwest knowledge of men, he speedily mat at that time. By finished manners, excellent sense, and regarded as an impossibility." Quoted in West, succeeded in accomplishing wnat every man 
broken by the groan of an engine. In another moment, the shrill whistle of a steamboat thrilled through the air. Another moment, and a bright flash of lightning revealed the welcome shape of a steamboat just rounding the bluffs, less than a mile below St. Paul. In an instant the welcome news flashed like electricity throughtout the town, and, regardless of the pelting rain, the raging wind, and the pealing thunder, almost the entire male population rushed to the landing as the fine steamboat "Dr. Franklin No. 2" dashed gallantly up to the landing. Before she was made fast to the moorings, she was boarded by the excited throng. The good captain and clerk (Captain Blakeley) were the great men of the hour. Gen. Taylor cannot be assailed with greater importunity for the 'loaves and fishes' than they were for news and newspapers. At length the news was known, and one glad shout resounded through the boat, taken up on shore and echoed from our beetling bluffs and rolling hills, proclaimed the bill for the organization of Minnesota Territory had become a law."

Sibley had taken up in Congress, or with the departments in Washington, other matters of importance to the people of Minnesota, but had not succeeded in getting favorable action on all of them. He did, however, succeed in getting the removal of the land office from St. Croix, Wisconsin, to Stillwater. It will be recalled that this matter had entered to some extent in the short campaign for delegate in 1848 . The Wisconsin members of Congress objected to the change and the matter was compromised by the creation of a land district for Wisconsin at Willow River. ${ }^{42}$ The people of Minnesota were especially interested in the construction of roads with federal assistance and in better mail service. Petitions asking for these things had been sent to Sibley and presented to Congress, but there was not sufficient time to get the desired results at this session of Congress.

a The opening of the land office at Willow River, six miles below Stillwater, and the transfer of the office from St. Croix to Stillwater were announced for June 30, 1849. Minmetota Register, April 27, 1849. Also Minnesota Chronicle, May 3r, 1849. 
Although the act for the organization of Minnesota Territory was approved by President Polk on March 3, 1849, the territorial appointments were left to the incoming administration. Two days after the inaguration, Sibley called upon President Taylor and the Secretary of State and submitted to them in writing an appeal that the offices of Secretary, United States Marshall, and Attorney should be filled with men from the new territory, and that the other offices be filled with men from the Northwest. Long before the passage of the act creating Minnesota, aspirants for office had written to Sibley to enlist his support in their behalf. Sibley recommended three Minnesota Whigs to the administration, and two of them were appointed. Henry L. Moss, of Stillwater, was appointed United States Attorney, and Joshua L. Taylor, also of Stillwater, was named Marshall, an appointment which he declined. The other appointments all went to men outside of Minnesota. The governorship, after having been declined by two other men, was accepted by Alexander Ramsey, an ex-Congressman from Pennsylvania. Charles K. Smith, of Ohio, became Secretary. Aaron Goodrich, of Tennessee, was appointed Chief Justice and David Cooper, of Maryland, and Bradley B. Meeker, of Kentucky, were appointed associate justices of the territorial court. After Joshua L. Taylor declined the office of Marshall, Colonel A. M. Mitchell, of Ohio, was appointed to the position. Governor Ramsey arrived in the Territory on May 27 , and issued a proclamation declaring the territory duly organized from and after June I, I $849.4^{43}$

Minnesota Pioneer, May 3r, 1849. 


\section{CHAPTER V}

\section{TERRITORIAL POLITICS, I 848 - 1852}

The settlers in the new territory were slow in developing political parties. Most of the fur traders, the earliest pioneers in the region, had never been identified with any political party. Many of them, as was the case with Sibley, had never lived in a State and, therefore, had never had an opportunity of voting in elections where national issues were involved. The same was probably true of many of the pioneer lumbermen and even of some of the pioneer farmers. Men in these classes of society often advanced along with the frontier, leaving one of the older territories before its admission into the Union as a State and taking up their residence in a newer region. In Minnesota, however, most of the leaders in the fur trade and early lumbering enterprises remained in the region as it was transformed from a wilderness inhabited by Indians to a settled community enjoying political organization. ${ }^{1}$ As time passed by, other classes of citizens came into the region and some of them came from the States where they had participated in political activity.

From the nature of conditions, the interests of pioneer settlers were local in character. The new communities were often hundreds of miles away from regions of compact settlement. There were few, if any, roads leading to the older settlements, and rivers constituted the principal highways for communication as well as trade. In a high latitude like Minnesota the rivers would be frozen over for several months of the year and the inhabitants deprived of even this means of communication with the outside world.

${ }^{1}$ H. H. Sibley, H. M. Rice, David Olmstead, H. L. Dousman, and N. W. Kittson all came into the upper Mississippi country as fur traders and all of them remained in the region and played prominent parts in the making of Minnesota. Although Dousman lived in Wisconsin he was interested in the affairs of Minnesota Territory. 
Even after territorial organization had been established, the questions confronting the settlers were local. Since their delegate in Congress could not vote they had no voice in determining national policies. Letters and newspapers came rarely and irregularly to the early settlers and it was difficult for them to know what was happening in the realm of national politics. It would not be, therefore, until the territory was well advanced towards statehood and men other than fur traders and pioneer lumbermen, including lawyers and newspaper editors, had come in that real party organization would come into existence. By I 849 men were beginning to speak of themselves as Whigs or Democrats, in some instances, especially the late comers, but party organization did not really come into existence for some years after that time. Politics were personal and factional and the voters of the territory lined up, for the most part, with one or another of the factions irrespective of the political leanings of the leader.

Since the territorial appointments for Minnesota had been made by a Whig administration, the officers were, of course, all Whigs and the territorial administration was a nucleus around which men with Whig sympathies rallied. Most of the important business men living in Minnesota at the time of its organization were, or were to be, Democrats and a majority of the people in the territory appear to have had Democratic leanings. ${ }^{2}$ This was probably true throughout the territorial period or at least until the organization of the Republican party drew to itself many men who had previously been Democrats.

Since the territory was dependent upon Congress not only for appropriations but also for the land grants which the inhabitants hoped to secure for public purposes in the territory and since the settlers would need the assistance of friends in both political parties in Congress in securing such aid, it seemed best to most of the leaders not to draw strict party lines. As time went by, the opponents of the Whig administration in the

\footnotetext{
${ }^{2}$ Ramsey to Hugh Tyler, Jan. 14, 1851 , in Ramsey Papers. Also Joseph R. Brown to Sibley, Jan. $30,1850$.
} 
territory gradually grew together and nominated opposition tickets for members of the territorial legislature, but, during the period 1849-1852, they did not secure control. Fusion tickets for county offices, composed of about equal numbers of Whigs and "neutral" Democrats, were nominated and usually were elected. This group took the name of Territorial party and its chief purpose was, as they said, to work only for the best interests of the territory. The opponents of this group claimed that the fusion idea was a clever scheme on the part of the Whig minority to divide the Democrats and thus control the territorial legislature. ${ }^{3}$

The two principal factions in the politics of the period were the Sibley and Rice factions, most of whose followers were, or were to be, Democrats. It was the Sibley faction which usually fused with the administration Whigs. So bitter was the hostility between Sibley and Rice that it gave color to the politics of the entire territorial period of Minnesota history. Henry M. Rice was at one time a member of the fur company of which Sibley was the head in the Northwest. Business differences arose between them and finally led to personal hostility which was carried over into politics and became the basis of the Sibley and Rice factions. ${ }^{4}$ It is difficult for the citizen of today to realize fully the bitterness of this controversy and the far reaching effects it had on territorial politics.

Fuel was continually added to the flames of personal and factional politics by the newspapers which made their appearance in Minnesota in 1849 . The first of these was the Minnesota Pioneer of which James M. Goodhue was editor. In the first issue, which appeared April 28, 1849, Goodhue assumed a neu-

W. D. Phillips to Sibley, Feb. 1, 1849 (1850).

The final break between the two men seems to have come about in 1848 -49 over the title to land in upper $\mathrm{St}$. $\mathrm{Paul}$. Rice had acquired land there and was selling and giving away lots to his followers. The for the benefit of the The property, charging Rice with fraud. The company was not successful in the suit, but the feeling of bitter-

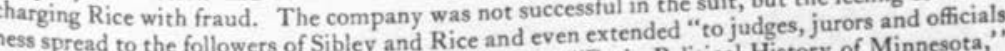
of the court, as well as to the legislature." Gilfillan, "Early Political History of Minnesota," in Minnesola Historical Collections, 9:170. 
tral position in politics and announced that his newspaper would support neither of the national political parties while Minnesota was a territory. Goodhue was a Democrat, however and the Pioneer was recognized as the organ of the Democratic party in the premature attempt at organization in October, 1849. As the fight between Sibley and Rice became more bitter and the Rice faction, which it at first supported, was defeated in the election in November, 1849 , the Pioneer lined up with the Sibley faction, although Goodhue was not fully trusted by Sibley's friends. ${ }^{5}$ The second newspaper started in the territory was the Minnesota Chronicle, the first number of which was issued on May 31,1849 . This was a Whig paper and James Hughes was its first editor. The next paper to appear, the Minnesota Register, ${ }^{6}$ was also Whig. Two Whig papers were more than the new territory could support and they were consolidated in August, 1849, and published as the Chronicle and Register until $185 \mathrm{I}$ when this paper was absorbed by the Democrat. The Minnesota Democrat was started in December, 1850 , in the interest of the Rice faction with Colonel D. A. Robinson as its first editor. After the consolidation of the Chronicle and Register with the Democrat another Whig paper, the Minnesotian, made its appearance. The chief competition between these newspapers was, of course, over the territorial printing. Although the administration was Whig, Goodhue succeeded in getting his share of the printing from the very first and, in 1851 , was made Territorial Printer. This latter action came as a result of a spirited fight in the territorial legislature. The Rice influence wanted to receive at least a share of the public printing, especially after gaining control of the

Soodhue was born in New Hampshire in 1810. After graduating at Amherst, he studied law and practiced for a time, then went to Wisconsin Territory and edited a newspaper. He came to Minnesota as soon as the territory was organized. He died in 1852 . Goodhue was a vigorous writer but was inclined to be sensational and at times vindictive. Minnesola Historical
Collections, 10:2.

The first number of the Register, dated April 27, 1849, was printed in Cincinnati and sent to Minnesota for distribution. Dr. A. Randall was then the editor. He sold his interest in the paper to Nathaniel Melean and went to California as a "forty-niner." The paper was then moved to St. Paul and publication was resumed in July, 1849 . 
Chronicle and Register, since that paper was openly Whig. The Sibley faction combined with certain Whigs in the territorial legislature and gave the contract to Goodhue. This was looked upon, therefore, as a victory for Sibley over Rice. ${ }^{?}$ These newspapers utilized factional politics as material for the editorial columns and this, together with their own fights over the territorial printing, added to the bitterness of the period.

It will be recalled that Rice had been a candidate in $\mathrm{I} 848$ in the election of a delegate from the residuum of Wisconsin Territory. Although defeated in that contest, he was by no means ready to give up the fight against Sibley. He did not, in fact, become an active candidate for delegate again until after Sibley's retirement from Congress, probably because he did not consider the prospects of success favorable enough, but his friends were continually trying to bring about Sibley's downfall. Rice was a skillful politician and had a large following outside the fur company influence and was very popular with a large number of people in Minnesota. Rice moved to St. Paul after Sibley left for Washington in the fall of 1848 and began building up a personal following at that place. ${ }^{8}$ He also had important business interests at Crow Wing on the upper Mississippi. On December I, 1848, Joseph R. Brown wrote to Sibley from Crow Wing that Sibley's friends there were greatly elated over his election, but that "war to the knife had been declared against all who assisted in any way in defeating the "universal favorite.", There was a rumor at that time that an effort would be made to organize the Democratic party in Minnesota with the view of favoring Rice against Sibley. ${ }^{\circ}$

7 "You will learn by this mail," Ramsey wrote to Sibley, Jan. $14,185 \mathrm{r}$, "of the election of Goodhue as printer. This is one of the greatest victories that your friends have yet achieved. . . At the opening of the session two weeks ago I very much feared that $R$. would get the advantage of us, but recent events dissipate that fear. Rice since the election of Goodhue they say is terribly cast down."

${ }^{8}$ Rice opened a business house in St. Paul in the fall of 1848 and spent most of his time there. He did not move his family from Mendota until June, 1849 , at the time that Ramsey came to St. Paul from his stay with Sibley at Mendota. Rice and Ramsey descended the river together in two large bark canoes managed by poyagears. Minnesofa Chronicle, June 28, 1849.

Walker to Sibley, Nov. 7,1848 . 
Sibley's success in Washington in securing territorial organization gave him such popularity with the people of Minnesota that no candidate opposed him for election as the first regular delegate from the new territory. A plan to organize the Democratic party had been carried along by the Rice faction, but the time was not ripe to bring it into the open. The first territorial election was held on August I, I849, and the politicians concerned themselves principally with candidates for the legislature. On the surface, party lines were not drawn and the leading men in the territory declared themselves in favor of "neutrality" in politics, but the different factions tried to get as many of their friends elected as possible. Both Rice and Sibley were active in the campaign for members of the legislature. ${ }^{10}$

The Minnesota Register announced Sibley's election in the following editorial: "The unanimous voice of the citizens of the territory, by which Mr. Sibley is called to represent them in Congress is a meritorious compliment to that gentleman highly creditable to our people. While partisan warfare is raging hot and fierce in the States, we in Minnesota are attending to our own business, and rewarding our best men, without regard to their political opinions. This is as it should be. Let us go on this way for a few years, and Uncle Sam will not be unmindful of all our wants." 11 The Pioneer did not mention Sibley's election until August 23, when the following editorial appeared: "The Hon. Mr. Sibley was elected delegate to Congress by the unanimous voice of Minnesota. As he was the choice of the whole people, without the least opposition, we almost forgot to mention that he was elected."

In September, 1849 , the Rice faction decided to come into the open with the plan to organize the Democratic party in
Minnesota. A caucus was held at the home of H. M. Rice on Monday evening, September 24, 1849, and a committee was

\footnotetext{
${ }^{10}$ Rice to MeKenny, July 13,1849 ; and G. H. Pond to Sibley, July 16,1849 , both in
Sibley Papers.

${ }^{11}$ Minnesota Register, Aug. 4, 1849.
} 
appointed to call a mass meeting of the democracy of Minnesota. This committee sent out the following call: "Believing that the safety and integrity of our party and the paramount interests of our infant territory demand that the party lines be henceforth drawn, we extend a cordial invitation to our Democratic brethern in all parts of the Territory to assemble at St. Paul on Saturday the 2oth day of October, to take measures to secure permanent thorough organization." ${ }_{12}$ This meeting was under the control of the Rice faction. Some Sibley men were named on the different committees, but the majority of the most important committees were Rice men. The resolutions reported to and adopted by the meeting struck hard at the policy of "neutrality" in territorial politics. Among other things, it was resolved "That we have no confidence in the profession of those who raise the cry of political neutrality in the Territory; that it is a specious and artful attempt to begile portions of the stronger party into the support of men and measures emanating wholly from the weaker one, and exclusively for the furtherance of partisan purposes, and that the interests of the people at large require that all such attempts be thwarted at once, which can only be effectually done by prompt, decided, and united action by the Democracy of this most beautiful land." The resolutions expressed "undiminished and abiding confidence" in the principles of Jefferson, Madison, Monroe, Jackson, and Polk, and stated that the Democrats of Minnesota were "opposed to a national bank, to a protective tariff as such, to the distribution of the proceeds of the sales of public lands, to a latitudinary construction of the Constitution, and to the abrogation of the veto power." Another resolution, offered from the floor and adopted, declared "That in organizing the Democratic party it is important that our trusts should not be placed in any but those who are openly and unequivocally Democrats, fearlessly advocating Democratic principles at all times." This last resolution was evidently intended to force "neutral" Democrats into the organization.

${ }^{12}$ Minnesota Picneer, Oct. $25,1849$. 
While this attempt to organize the Democratic party was premature, it did have momentous consequences for Sibley for it was at this meeting that his affiliation with the Democratic party was first announced. He had been invited to attend the meeting but was unable to do so, he said, because of pressing business engagements. He did, however, send a letter which was read at the meeting. In this letter Sibley stated that he had hoped that party lines would not be drawn in Minnesota, but, since they "were already virtually drawn," he would avail himself of this opportunity of stating his individual sentiments. "I am a Democrat of the Jeffersonian school," he wrote, "and as such I stand ready at all proper times and places to take my place under the banner of the party. It is especially proper that I should define my position now, as a false statement has been circulated about that I was a Whig, and elected as such." He stated, however, that, since he had been elected without reference to party, he would preserve his previous neutrality in the discharge of his public duties. ${ }^{13}$

The men who participated in this meeting seemed to believe that they had put an end to neutrality in territorial politics and caused the following notice to appear in the next issue of the Pioneer: "Died suddenly, in Minnesota, on the 2oth inst. at 9 o'clock P.M. the 'Territorial Party.' Disease, delirium tremens, induced by a secret habit of imbibing Whig spirits."

This organization of the Democratic party, and especially Sibley's letter, was bitterly denounced by the Whig members of the Territorial party. "On Sunday it was hazardous to run the gauntlet on Third Street," wrote Goodhue in an editorial in the Pioneer. "The Territorial Party are awfully flustered. The letter of the Hon. Mr. Sibley to the Democratic Convention, announcing himself a Jeffersonian Democrat, took them raking like a charge of duck shot from a French shot gun discharged at a flock of wild geese in a fog. Never, in our opinion, did a party sleep under a mine of surer destruction than that which Federalism had prepared in Minnesota for the Democ-

"Minnesota Pioneer, Oct. 25, 1849. 
racy. Long may it be before the party of human hopes and human progress here shall again lie down in dalliance with Federalism." The attitude of the Whigs towards Sibley was well shown in an editorial in the Chronicle of November 3: "Mr. Sibley has a perfect right to form and express his own opinions when and where he may deem proper. He was elected, according to his own showing, without reference to party politics, and has graciously promised to act out his term without politics. After that, look out, the Fur will fly. Pending the election, so far as the subject was mooted, he was claimed by both. Rushing into the arena at this particular time, without any necessity, we think, instead of increasing his influence at home or in Washington will have a most decided contrary effect." This prophecy was to be fulfilled.

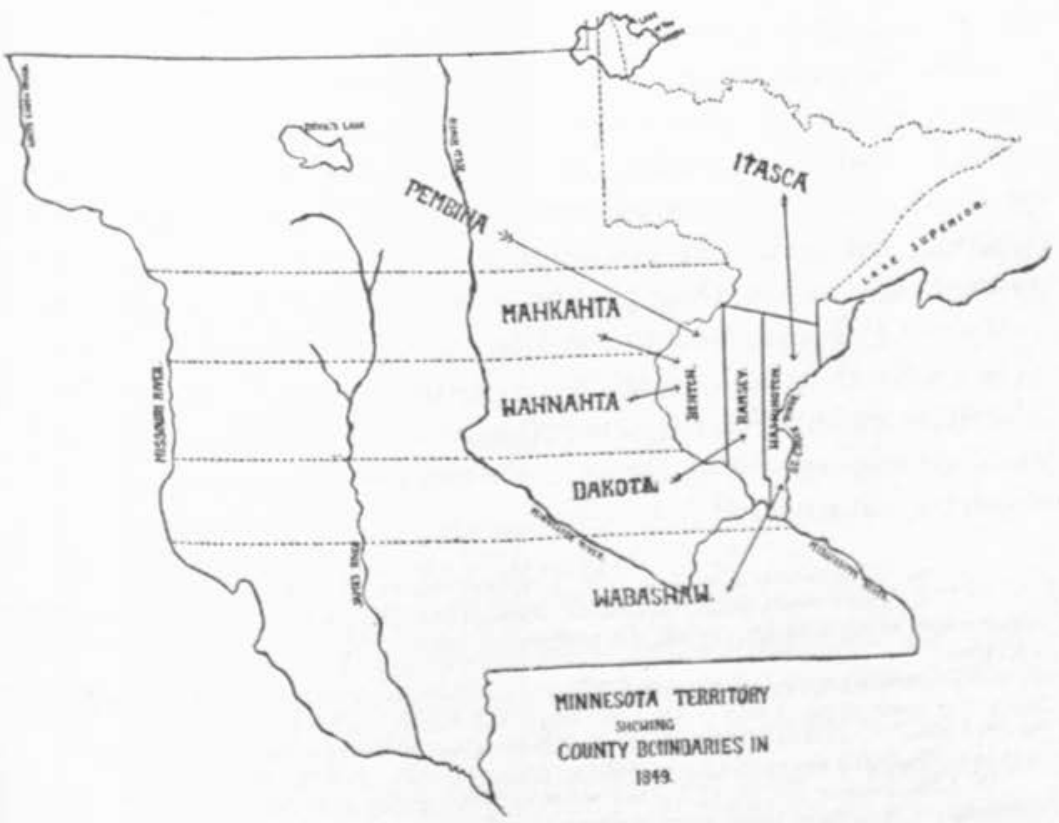

The first territorial legislature was in session from September to November, 1849 , and, on October 27 , enacted a law creating 
nine new countries, three of which were declared to be fully organized. These countries were Washington, Ramsey, and Benton. ${ }^{14}$ This law provided for the appointment of county officers by the Governor to hold office until a regular election could be held. This election was in November, I 849 , and gave the first opportunity to test the strength of the recently organized Democratic party. The next move on the part of Rice, was, therefore, to put a Democratic ticket, composed mostly of his followers, into the field in Ramsey County, the countyseat of which was St. Paul. ${ }^{15}$ The men recently appointed by Governor Ramsey were candidates for re-election, and some of them were "neutral" Democrats who had belonged to the Territorial party. The "organization" Democrats charged that the Whigs had secretly organized during the session of the legislature and by that action had forced organization upon the Democrats.

The "organization" Democrats of Ramsey County met in convention on November I 7 to nominate candidates for county offices. The Rice faction, by calling the convention to order promptly at the appointed time before all of the delegates had arrived, succeeded in nominating its slate. ${ }^{16}$ Goodhue supported this ticket through the columns of the Pioneer, but, in spite of all that he and the Rice faction could do, the ticket was badly defeated. The followers of Sibley did not support the Rice ticket and they, together with the Whigs, succeeded in electing, with one or two exceptions, the appointees of Governor Ramsey. ${ }^{17}$

16 Lates of Minnesota, 1849 , p. 9. (See accompanying map for boundaries.)
is $\mathrm{J}$. R. Brown wrote to Sibley, Dec, 21, 1849: "The object then was to ascertain how the clique would stand with to Sibley, Dec. 21,1849 : "The object then was to ascertain how the clique would stand with the people, if a nomination (of Rice for delegate) could be obtained
hereafter."

under the name a pretty smart attempt," Henry Lambert wrote to Sibley, Nov. 27 , "at a gag pointed time. there they had little They had everything their own way and when Brown, Rollins, \& us got

${ }^{17}$ After the election, W. H. Forbes on. Naturally they felt indignant."

H. Forbes wrote to Sibley giving an account of the meeting and won the day and we he heard ere this the result of our county election. The peoples' ticket had the impude weried on that day I trust the last effort of that Rice faction. . . . They convention and saw to call themselves the democratic pa:ty. I walked up to their nominating parts of the Territory." 
The Whigs were inclined to look upon this election as a Whig victory in spite of the fact that there was no open organization of that party in the territory. They were very bitter against Sibley for his letter of October 20 and gave him and his friends little credit for the victory. The seeds which were to bear fruit in the campaign of 1850 had now been sown. Sibley had not used his influence in favor of the Democratic ticket, and thereby caused more hostility than ever between himself and Rice. On the other hand, the Whigs had denounced him for abandoning neutrality. Both of these facts were to have influence when Sibley came up for re-election in $185^{\circ}$.

Sibley announced his intention of running as a neutral candidate in a letter of July 26, I850, to Governor Ramsey. "It is with unaffected reluctance," he wrote, "that I consent to run again, and I only do so because I conscientiously believe that certain parties wish to gain control in the Territory to effect their own selfish ends. To defeat the united cliques of Rice, Mitchell, the Ewings, and others of a like stamp I will make any personal sacrifice of my own comfort and inclinations. After what has been done for M. (Minnesota) at this session, in the face of every opposing influence and during a period when nobody else has accomplished anything, it would seem strange indeed if the people should decide against me in September." Sibley hoped that Mitchell would be the candidate against him. He wanted to come to Minnesota during the campaign but feared that he would be unable to do so because important measures were still pending in Congress which needed his constant attention.

Colonel A. M. Mitchell, the Whig Marshall of the Territory was nominated by a convention which called itself the Territorial party, on July $3 \mathrm{I}, \mathrm{I} 850$. This convention seems to have been called as a Whig convention and was to have been composed of delegates from the organized counties of Washington, Ramsey, and Benton. Apparently the Mitchell forces were not willing to abide by the probable action of the convention as it would have been composed with the delegates chosen by 
the Whigs. The Mitchell followers, together with the Rice faction among the Democrats, hurriedly elected twelve delegates to the convention which met the same night and, assisted by the anti-fur-company delegation from St. Anthony, nominated Mitchell. The majority of the St. Croix delegation and the delegates from the prairie section refused to go into the convention when they saw how things were going, and many of the leading Whigs announced that they would not support Mitchell. Even Furber, who had been so bitter against Sibley, announced that he would support Sibley before he would Mitchell. ${ }^{18}$

This convention which nominated Mitchell made the American Fur Company a leading issue in the campaign. A resolution adopted by the convention declared "That we have in our midst a dangerous monopoly known as the 'American Fur Company,' wielding a powerful influence, injurious to and destructive of the community at large, prepared by any means to retain their baneful influences at the sacrifice of the welfare and independence of our people; and we do therefore pledge ourselves, and call upon our constituents to assist in checking its power." 19 A letter was sent to Mitchell notifying him of his nomination and he replied immediately accepting it.

Sibley's friends recognized that the union between the Rice and Mitchell factions was a formidable combination and that it would require a hard fight to defeat it. ${ }^{20}$ Sibley's candidacy was publicly announced in the Pioneer of August 8, $185^{\circ}$. Goodhue had not yet abandoned the Democratic organization, and he simply announced that he had been requested to say that Sibley would be a candidate. He regretted, he said, that party lines would probably not be drawn during the campaign and that, in the absence of party issues, politics would be personal and factional and were certain to be bitter. "We organ-

${ }^{18}$ Potts to Sibley, Aug. 1, 1850.

${ }^{10}$ Minnesola Pioneer, Aug. 8, 1850.

with, to my surprise, great prospects of success" 
ized," he wrote, "neither a Sibley party nor a Rice party, but the Democratic Party." He called upon the Democratic committee to call a convention and gave notice that, if they did not do so within a week, he would "feel at liberty to nominate a good, staunch, unflinching Democrat." "In regard to the mongrel nomination already made," he continued, "we have no sympathy with it or with any that may be made in immitation of it. We recognize no distinctions based upon pelfry, and have nothing to do with their contests."

No satisfactory call was issued by the Democratic committee, and Goodhue, in an editorial of two and one half columns in the Pioneer of August 15, came out strongly for Sibley whose name was placed at the head of the editorial with the subheading, "An honest man is the noblest work of God." Goodhue gave a résumé of Sibley's work in Washington, stating that Sibley was "the man by whose agency Minnesota was quarried and hewn into an organized territory." Sibley's reliability and his standing in the community, before the fight against him was begun, were emphasized, and the people of Minnesota were urged to "Hold fast to that which is true, tried, and valuable. Do not exchange a delegate for a chance of a delegate. Be deliberate and honest; be wise and not fools."

A group of Whigs met in convention at Stillwater on August 10, 1850, and nominated Colonel N. Greene Wilcox for delegate. This was the nearest that the Whigs came to organizing that party throughout the territory during the period under consideration. ${ }^{21}$ It was not successful, however, and, on August 18 , Wilcox declined the nomination and announced that he favored the candidacy of Mitchell.

Still another nomination was made. On August 10, David Olmstead was nominated by a convention in St. Paul. This meeting approved the administration of Governor Ramsey, probably hoping for the support of the territorial administration, although Olmstead himself was a Democrat. The Chronicle and Register approved Olmstead's nomination. "For moral ${ }^{21}$ Minnesota Pioneer, Aug. 15, 1850. Also Chronicle and Register, Aug. 12, 1850. 
worth, ability, and long tried integrity," the editorial stated, "he (Olmstead) has no superior in the Territory, and if his friends do their duty he will be elected." 22

The campaign resolved itself, therefore, into a threecornered fight between factions. Sibley was unmercifully denounced for his connection with the fur company. It has been said of this campaign that the real issue was "Fur versus antifur." Much was said during the campaign about the "Dangerous monopoly" and its "baneful influence" in the new territory. This argument, if such it may be called, was ably answered through the columns of the Pioneer. In an article of two and one-half columns, signed by "A Whig," it was denied that the fur company was a monopoly, and it was even defended as being a good thing for the territory. "If there was a hundred fur companies in the territory," said the article, "so much the better. I am sorry to see this hue and cry against monopolies raised here in Minnesota. Those who have raised it, and who join in it, cannot be aware of the origin of the course they are pursuing. Monopolies have ever been the theme of demagogues and unprincipled men in all past time. The truth is, and there is no disguising the fact, this cry against monopolies is a pitiful humbug, originating with the wicked to impose on the ignorant. The disappointments of a few, the ambitions of some, and the prejudices of others, are put together; a little froth is made about election times; it serves its purpose and then sinks to nothing, whence it came, and there is no more of it till another election." 23

The same line of argument was followed in an editorial of one and one-half columns in the Pioneer of August 22. Goodhue gave an account of fur company methods in Minnesota and denied that the fur company with which Sibley was connected was a monopoly, since anyone who could take out a license could take part in the fur trade. "Unmasked," he wrote, "it

\footnotetext{
"Chronicle and Register, Aug. 12,1850 .
${ }^{2}$ Minnesota Pioneer, Aug. 15, 1850.
} 
(the cry against monoplies) is nothing more or less than an attempt to array labor against capital. It seeks to stir up envy. It is an old trick of demagogues attempted in a new Territory."

The friends of Olmstead denounced Goodhue for not supporting what they were pleased to call the Democratic candidate. Goodhue defended himself and Sibley in an able editorial of August 22. He affirmed that Sibley had been announced as a candidate before the meeting of the convention that had nominated Olmstead and that Sibley "had never pledged himself to be tricked out of office by any sliding under of cards or the dextrous turning up of Fack"; Goodhue declared that the convention itself "was all arranged expressly for Mr. Olmstead. The notices were printed, the wires laid, and the whole scheme concocted before Mr. Sibley's friends had any notice of it. Was Mr. Sibley to be led into this palpable trap? If our friends in Washington county had not been shamefully duped in this business, Mr. Olmstead would never have been thrust up as a candidate; he won't know after election that he was a candidate, without reference to the poll-books, under the head "Scattering." ${ }^{24}$

As the campaign progressed it became evident that the chief issue was "anything to beat Sibley." A conference was arranged between the Olmstead and Mitchell forces and Olmstead was induced to withdraw from the contest. He seems to have done this against the advice of some of his most influential friends. Joseph R. Brown, although a personal friend of Sibley, was supporting Olmstead because he was running as a Democrat. He urged Olmstead to stay in the race, believing, so he wrote to Sibley, that Olmstead would get votes in Benton county which would otherwise go to Mitchell. ${ }^{25}$ The Chronicle and Register, which had supported Olmstead, also opposed his withdrawal. It accused the Sibley faction of treachery in that they had promised, so it was claimed, to enter the "Democratic"

${ }^{24}$ Minnesota Pioneer, Aug. 22, 1850 .

${ }^{25} \mathrm{~J}$. R. Brown to Sibley, Aug. 28, 1850. 
convention which nominated Olmstead. "The faithless course pursued by these gentlemen," said the editorial, "in bolting the nomination when it was ascertained that their personal preferences could not be gratified, and the boasts subsequently so often repeated, that with two candidates in the field to divide the American vote, they could with their French vote elect Mr. Sibley, were undoubtedly the causes which determined Mr. Olmstead in withdrawing." ${ }_{26}$

Sibley remained in Washington during the campaign, but he kept in touch with the course of events in Minnesota. Governor Ramsey wrote to him often and kept him informed in regard to political conditions at home. The election was held on September 2, I850, and, as was to be expected after such an exciting campaign, did not pass off without some disorder. Joseph R. Brown wrote to Sibley that there had been many attempts to buy votes and to intimidate voters, especially in the "upper town" of St. Paul and with the French Canadians, among whom a circular had been scattered broadcast charging that Sibley had sacrificed their claims in the Military Reserve to his own advantage and to the advantage of the fur company. ${ }^{27}$ Goodhue gave the following account of the election in an editorial in the Pioneer of September 2: "Never before have we witnessed an election, as hotly contested as our election last Monday. If an empire had been at stake, more zeal, more influence, more active, unscrupulous means and more indefatigable exertions could not have been called into existence. Hope, fear, avarice, ambition, personal obligations, money, whiskey, oysters, patronage, contracts, champaign, loans, the promise of favors, jealousy, personal prejudice, envy, everything that could be tortured into a motive has been pressed into the canvass. Mr. Sibley was absent in Washington. This was a great disadvantage to him in an election,

* Chronicle and Register, Sept. 2, 1850 . No evidence has been found of such statements having been made during the campaign by Sibley's friends. Good politicians would not openly talk that way. The French vote was for Sibley, however, and two opposing candidates would
have favored him.

${ }^{27}$ Brown to Sibley, Sept. 4, 18 50. 
turning as it did, so much upon personal preference. Any other man in Minnesota, being a candidate, and distant hundreds of miles from the canvass, would have been signally defeated. Colonel Mitchell and Captain Olmstead were both here, actively electioneering; as well as Mr. H. M. Rice, a man of unlimited energy and great resources. ... Bets amounting to hundreds of dollars were made; and much larger sums would have been bet, if the Winnebago payment had not been delayed. Both sides were willing to bet anything, to the last shirt. One of Mitchell's friends wore his bosom-pin stuck, not in his shirt bosom, but into the flesh upon his breast; and would have bet off the pin itself, upon the slightest banter. We desire never to see another election, so wicked and corrupt; but whenever men attempt to elevate a man to office by corrupting the fountains of popular will, we only ask to see him as signally defeated as Colonel Mitchell has been by the untied exertions of good men of all parties."

The factional fights in Minnesota continued during most of the territorial period. This was particularly true in the territorial legislature in the session of $185 \mathrm{I}$. The factions were almost evenly divided and a sharp contest took place before organization was effected. "It is said in the Council," William Holcombe wrote to Sibley on January 8, 1851, "that before the President (of the Council) was elected, the Capitol was located, the Penitentiary was located, the Public Printing disposed of, and all the minor offices down even to firemen." This was the time when Goodhue was made Territorial Printer, as related in a former connection.

As time passed by, it appeared that Rice was gaining strength. "There is no use denying the fact," John H. Stevens wrote to Sibley, "that most of the new comers are Rice men. $\mathrm{He}$ can feed them on promises, by which course he can make more than by paying ready cash down. Now the question, arises what course shall we take to secure the emigrant vote?" The feeling also became stronger that the Democrats should lay aside their factional fights and effect a real organization. 
Friends of both Sibley and Rice tried to bring about a reconciliation between them and succeeded to some extent in doing so. ${ }^{28}$ Sibley retired from Congress at the expiration of his term, and Rice was elected to succeed him. Sibley's greatest strength during this period seems to have been due to the fur company influence. As conducted by Sibley, the fur company's methods were popular with the early settlers, many of whom Sibley had befriended at different times. The company had been considerably discredited, however, while Sibley was in Washington, ${ }^{29}$ and the fight between Sibley and Rice, which was after all largely a fight between rival trading interests, had brought it into an unfavorable light. With the increase of population, the new comers were acquainted with the company methods only as conducted by Dr. C. W. Borup, who was in charge while Sibley was in Washington, and they were naturally prejudiced against it. When they outnumbered the early settlers, Sibley lost his great influence in the territory. The high tide of Sibley's popularity during the period of his congressional career was in 1849 when he returned with territorial organization and while his politics were yet unknown. His influence then waned until he closed up his connection with the fur company, which he did soon after the expiration of his term in Congress. His retirement to private life was not permanent, however, and greater honors, both civil and military, were in store for him.

\footnotetext{
2s Rice to Sibley, Feb. 3, 1853 .

$\Rightarrow$ Potts to Sibley, April 17, 1850; John H. Stevens to Sibley, May 22, 1850; and N. W. Kittaon to Fred Sibley, Aug. 12, 1850, all in Sibley Papers.
} 


\section{CHAPTER VI}

\section{THE NEEDS OF A NEW TERRITORY}

Providing territorial organization was only the beginning of federal legislation in behalf of the inhabitants of a frontier region. The people of Minnesota wanted better postal service, appropriations or land grants for public buildings, roads, schools, a university, and even telegraph lines and railroads. Indian treaties for the cession of land for settlement by the rapidly increasing population and to attract a still larger immigration were ardently desired. On all of these measures Sibley worked with the same energy and skill as had characterized his efforts to secure territorial organization during the preceding session of Congress, and he faced even greater difficulties in their accomplishment.

The slavery question was being agitated more bitterly than ever before and claimed more time and attention on the part of Congress. This struggle began on the first day of the session over the organization of the House, where no party had a majority. There were 112 Democrats, 105 Whigs, and 13 Free-Soilers. The latter, therefore, held the balance of power and could prevent or delay the organization of the House. This they proceeded to do and it was not until December 22, 1849 , and on the sixty-third roll-call, that a Speaker was chosen and this was accomplished by a plurality rather than a majority vote. $^{1}$ It required about another month before the House was completely organized and ready for the transaction of business. By this time both sides to the slavery controversy were fully aroused and the discussions which finally led to the Compromise of 1850 were well under way. It was evident, therefore, that it would be very difficult to get the attention of Congress for

\footnotetext{
1 Congressional Globe, 31 Cong. I Sess., p. 66.
} 
the consideration of measures desired by an infant territory on the northwestern frontier.

Provision had been made in the appropriation to carry the Minnesota Act into effect, passed during the last hours of the preceeding session, for the establishment of a temporary capital at St. Paul, including money for the erection of temporary buildings. No provision was made, however, for a penitentiary, an institution of vital importance to a new territory. There was no place within the limits of Minnesota for the confinement of criminals. The military authorities at Fort Snelling consented to receive and confine criminals as a temporary expedient, ${ }^{2}$ but they were not required to do so and the people of Minnesota were greatly concerned for an appropriation to enable them to care for criminals in a proper institution. Incidentally, too, it would help satisfy one of the new towns in the territory if the penitentiary could be secured for it, in return for the capital being elsewhere. Sibley secured an appropriation of $\$ 20,000$ for the erection of a penitentiary. He encountered some opposition from the "ultra-strict constructionists," but, as he wrote, he had "paved the way for success by long and persevering electioneering previously.",

Another matter of considerable importance to Minnesota was the adequate codification of the law applicable within its limits. The first territorial legislature had made provision for the application of the Wisconsin code of laws until and except as the same should be amended or repealed by the Minnesota legislature. Since there was not sufficient time during the sixty day session to prepare a full code, Congress was memorialized for permission to extend the next session of the territorial legislature to ninety days. Sibley finally secured the passage of such a bill and the laws were properly codified in $1851 .^{4}$

${ }^{2}$ Ramsey to Sibley, March 31 , 1850.

'Sibley to Ramsey, May 30,1850 , in

I Sess, 1074 , 1080 , 1169 . Additonal 50 , in Ramsey Papers. Also Congressional Globe, $3 \mathrm{r}$ Cong. the buildings. Congressionel $G$ tonal appropriations were secured at the next session to complete Congressional career some 285,6732 Cong. I Sess., 102. During the five sessions of Sibley's

'Congressional Globe, $328,673.43$ were appropriated for Minnesota. 
On January 3, 1850 , Sibley gave notice of his intention to introduce certain bills for the benefit of Minnesota Territory, dealing chiefly with the establishment of post-roads. The subject of communication with the outside world was of vital concern to the people of Minnesota and most of the letters to Sibley during this period contained references to, or definite suggestions regarding, the laying out of post-roads and the securing of more frequent mail service. The territorial legislature memorialized Congress on the subject and the memorial had been presented by Sibley. The population was rapidly increasing and the people believed that they were entitled to more frequent and more regular service. The Post Office Department, on the other hand, thought that the receipts of the post offices in Minnesota were not sufficient to warrant the increased expenditure. ${ }^{5}$ On February 12, 1850, Sibley wrote to the Postmaster General urging additional mails and on February 28, he was informed that the postmaster at Galena, as well as the one at St. Paul, had been directed to send mail on packet boats as often as they should run. The postage was to be two cents for each letter and one cent for each newspaper and was to be paid by the postmaster receiving the mail from the boat. The contractor on the mail route between St. Paul and Stillwater was directed to run one additional weekly trip over the route. ${ }^{6}$ Not only was more frequent service wanted but there was a strong demand for additional routes to reach the settlements not already served. Consequently, on February 6, 1850, Sibley introduced a resolution instructing the Committee on Post Roads "to inquire into the expediency of establishing a route from Point Douglas, via Cottage Grove, Red Rock, St. Paul, and the Falls of St. Anthony, to Fort Gaines; and also to Long Prairie and Pembina; and from Point Douglas, via Stillwater, Marine Mills,

\footnotetext{
The First Assistant Postmaster General wrote to Sibley, Feb. 3, 1890 , declining to additional service because of excess of cost over receipts.

"Minnnesofa Pioneer, April 2, 1850 . Chronicle and Register, April 6, 1850. The latter paper announced this as "the best news of the season."
} 
Falls of St. Croix, and Pockegowa, to Fon du Lac." Closely associated with this question was the construction of roads to and in Minnesota. These were intended to facilitate the transportation of the mails, the movement of troops and military supplies, and to stimulate materially immigration to the territory. Some roads were constructed, of course, by the territory but, since its revenues were necessarily limited, the settlers believed that Congress should give assistance. The newspapers of the territory agitated the question and petitions and memorials were sent to Congress asking for appropriations for this purpose. ${ }^{7}$ It was believed that a more direct route could be followed between Milwaukee and St. Paul and save many miles of travel between the two places. It was reported that fairly good roads had been built from eastern Wisconsin as far as Stevens Point and, although no survey had been made, it was believed that the gap between these roads and Minnesota was not over 175 miles and that a road could be constructed for $\$ 5,000.8$ Sibley introduced a bill providing for the construction of five roads in Minnesota and carrying appropriations for $\$ 40,000$. These roads were to follow the plans for the post roads, mentioned above, or very nearly so, and they were to be constructed "under the direction of the Secretary of War, pursuant to contracts made by him." 9 Although the bill was the occasion for a lengthy debate over internal improvements, it was finally passed.10 As usual in such cases the original estimate of the cost of construction fell short of the actual cost and further appropriations were necessary in order to complete the work.

Closely associated with the construction of roads was the question of the improvement of the Mississippi river as a " "Is Congress aware," Goodhue wrote in an editorial, "that the road up the river from
St. Paul, for more than 100 miles, is absolutely thronged with travel, even now, in the dead of
winter?" Pioneer, Jan. winter?" Pioneer, Jan. 2, 1850 , p. 2 .

'It was expected that such a road would greatly stimulate immigration. "As the public
lands are mostly taken up in this part of Wing and if a good route could be opened to the Wisconsin, attention is directed towards Minnesota people within the next two years," He Territory, there would be a large emigration of eastern

"Congressional Globe, 31 Cong. 1 Sess., 1089. 
highway of trade and communication. As early as 1850 , the settlers petitioned Congress for appropriations for the survey of the Mississippi above the Falls of St. Anthony with a view to its improvement, and during the following session of Congress they petitioned for an appropriation of $\$ 10,000$ to remove obstructions in the navigation of the river between Fort Snelling and St. Anthony Falls. Sibley's efforts in behalf of these measures were not rewarded with success and the attempt to make St. Anthony Falls the head of navigation on the Mississippi was left to a later generation. ${ }^{11}$

The settlers in Minnesota also attempted to secure appropriations or land grants for the construction of a telegraph line from St. Paul to Prairie du Chien and also for the construction of railroads. They not only wanted railroads to establish connections with the East but these pioneers along the upper Mississippi filled with the enthusiasm and optimism characteristic of the frontier were, as early as $185^{\circ}$, dreaming and seeing visions of a railroad to the Pacific. It was at this time that California was admitted into the Union and plans were being made to construct a line across the plains and over the mountains to bring her nearer in point of time to her sister States. Sibley had been interested in a Pacific railroad since 1849 when he had been invited to attend a national convention in St. Louis "to deliberate upon the expediency and necessity of connecting, at an early date, the Pacific with the Mississippi valley, by means of a railroad and magnetic telegraph." 12 Goodhue, at different times during $185^{\circ}$, advocated the construction of a Pacific railroad and argued in favor of making St. Paul the eastern terminus. He pointed out that the distance from St. Paul to the Pacific was shorter than from St. Louis to San Francisco and that it would be far easier and safer to build the road westward from Minnesota. He favored

11 The problem was not really solved until the completion of the high dam near Fort Snelling in 1917 which finally makes possible the realization of the dream of the carly pioncers, although as yet there is very littie use made of the municipal pier at Minneapolis.

${ }^{12}$ A printed invitation to Sibley, dated August 28,1849 , is in the Sibley Papers. The invitation was in circular form and gave arguments in favor of the construction of such a road. 
building it along the route from Red River of the North used by Hudson's Bay Company. ${ }^{13}$

Minnesota was more immediately interested, however, in a railroad to connect with the lines which were at that time being pushed westward from Chicago towards the Mississippi, and thus secure a transportation system which would be in operation throughout the year. Editorials in the local newspapers stated that the natural dependence of Minnesota upon St. Louis would soon be severed and that the railroad from Chicago to the Mississippi would "revolutionize the course of trade in the Northwest." ${ }^{15}$ The people should look forward to this situation, it was urged, and favor the building of railroads. Bills were introduced into Congress to grant alternate sections of land, similar to the Illinois Central grant of that same year, to construct a railroad from the Falls of St. Croix to Lake Superior, one from Green Bay to St. Paul, and one from Milwaukee to the Mississippi. ${ }^{16}$ These grants would be made to Wisconsin, of course, but were of interest to the people of Minnesota. Minnesota was also interested in a railroad entirely within the territory. "Our railroad bill," Sibley wrote to Ramsey, "giving us alternate sections on each side of the road for six miles, from the western boundary of the Territory (the Missouri river) via Lake Traverse and the Big Bend of the St. Peters to the Iowa line in the direction of Dubuque passed the Senate yesterday. Its fate in the House is still doubtful. ${ }^{17}$ Sibley worked hard for the passage of the bill by the House and for a time it seemed that he would succeed. On August I5, 1850 , he wrote to Ramsey that he had secured a special meeting of the Committee on Public Lands and that it had agreed "by unanimous vote" to report the bill to the House. "I am now

13 Pioneer, May 9, 1850 , and Dec. 5, 1850.

celebrated by an excursion Chicago and the Mississippi was completed in 1854 . Its opening was sountry, including ex-presid the Mississippi to St. Paul, participated in by leading men of the ${ }_{16}$ Chronicle and Register, Fillmore and George Bancroft. West, Sibley, 214.

18 Congressional Register, April 20, 1850.

17 Sibley to Ramsey, July Cong. I Sess., 1456.

I Sess., 1409 . 
sanguine of its passage," Sibley wrote, "as it has already been passed by the Senate." A month later, however, he decided to let the bill go over to the next session of Congress. He wrote to Ramsey on September I 5, that the bill had been unanimously reported back to the House by the Committee on Public Lands but that he feared to bring it forward "because of an unfavorable vote on the Tariff yesterday in the House, which has so enraged the advocates of that measure in the northern and middle States, that they swear they will go against any and all grants of land to the West for making roads." Thus an unfavorable vote on the Tariff, a matter in which Sibley had no voice, caused a postponement of action on the bill and meant a delay of several years in the construction of railroads in Minnesota. The people of the territory did not give up hope of securing land grants, however, and Sibley introduced similar bills at later sessions of Congress, but, in spite of his efforts in their behalf, none of them were passed during this period. ${ }^{18}$

The pioneers of a new region who were laying the foundations of a new State were always anxious about the land policy of the federal government and especially the disposal of lands within the boundaries of the proposed commonwealth. The ideas of pre-emption and home-stead laws originated in the West and western men were the most earnest advocates of a change in the public land policy whereby the public domain would be used to encourage settlement rather than as a source of revenue. Sibley's ideas on this important question were typical of western men. He made an important speech in Congress on April 24, 1852, in which he discussed the homestead bill and the bill proposing to donate lands in the territories to the older States for the care of the indigent insane. ${ }^{19}$ Some of Sibley's arguments on the homestead bill had been made before his time and were made over and over again before the final passage of the homestead bill in 1862 . Sibley argued that some

\footnotetext{
18 Samuel Thatcher to Sibley, Jan. 2, 1851. Also Congressional Globe, 32 Cong. I Sess., 21; and 32 Cong. 2 Sess., 198.

is Congressional Globe, 32 Cong. I Sess., App. 485-488.
} 
change in the land system was necessary and that the laws should be so modified as "to produce a greater amount of practical good to the people." The passage of a homestead law, he asserted, would injure no class of our citizens. He met the argument that had been directed against the bill that the decrease in the receipts from the sales of public lands would mean increased taxation by maintaining that free lands would increase settlement, which in turn would increase importations and thus bring larger amounts of money into the United States Treasury from import duties. The increase in the sales of public land had not kept pace with the increase in population, he asserted, and the high prices of land had "forced thousands upon thousands to remain in the corrupting atmosphere of your large cities, who otherwise would have become contented and happy tillers of the soil." The government should favor the increase and welfare of the industrial classes because it was upon them that "the future hopes of the Republic must rest." Continuing, Sibley said: "Sir, I have never spent a month in any State of this Union. My life has been passed in the Territories upon the outer verge of civilization. I know the character of the pioneer, and of the men who even now are on their way to the West, and I speak understandingly when I say that it is in such homes as this bill, if adopted, will create, which will forever remain the nurseries of that love of freedom by which alone our present happy form of government can be perpetuated. From the abodes of the working classes of your inland population there will issue, in the hour of danger to the country, a power not only self-sustaining but abundantly able to bear the ship of state through all the storms that may beset her."

The bill for the relief of the indigent insane in the older States proposed to grant the title to certain lands in the territories to the States to be used for that purpose. Sibley reflected the typical western attitude towards such a measure. He opposed granting the land itself because such a procedure would retard settlement, but he favored instead the turning over to 
the States for the relief of the indigent insane the proceeds of the sale of the first $10,000,000$ acres of land which might be sold. The principles of the bill under consideration, he asserted, would cause Minnesota to "languish under a system of nonresident proprietorship which has hitherto, but to a less extent, been the bane and the curse of the West." It was unfair to the settlers of a new region for the government to do anything that would tend to retard settlement and thus delay the formation of State governments. "Sir, when these temporary governments were established there was an implied but solemn pledge given by Congress that so soon as the increase of population would justify it, the Territories should be admitted, in accordance with established precedent, into the Union, with the same advantages and upon an equal footing with the original States, in all respects whatever. It is with this assurance that Minnesota and Oregon are now augmenting in population with unexampled rapidity and no man immigrates to either who does not look forward to their speedy admission into this Union. It is this expectation which nerves the settler to meet all the trials, and overcome all the difficulties which fall to the lot of those who lead the vanguard of civilization. ... The Minnesotians are a peaceful and law-respecting people; but it may well be imagined that after they have penetrated the wilderness, endured all the trials and sufferings inseparable from the settlement of a new territory, made sacrifices of every kind in advancing the interests of our beautiful Territory and built up villages and towns by the labor of their hands, with a view to meet the wants and requirements of a rapidly increasing population, I say it may readily be imagined that they would not be prepared to greet with much cordiality the commissaries of the States who might go among them 'to spy out the land' which their own toil had rendered valuable in order to secure its transfer to absentee proprietors to the exclusion of the friends and former neighbors of the pioneers of the country." Sibley had the satisfaction of seeing the bill for the transfer of lands to the States for the relief of the indigent 
insane fail to become a law. He did not oppose affording proper relief to any class of unfortunate people, but he did oppose with all his might the transfer of title to lands within the territories to the States.

The people of Minnesota were also interested in having the military reserve at Fort Snelling greatly decreased in size. In I 805 when Lieutenant Pike had made his exploring expedition up the Mississippi, he had negotiated a treaty with the Indians for the cession of lands for a military reserve west of that river in the region of the St. Peters. In I8 I 9 Congress appropriated $\$ 2,000$ to carry this part of the treaty into effect and the military post which was soon called Fort Snelling was established. In 1839 the limits of the reserve were finally established and included some 55,000 acres of the most desirable lands in Minnesota. With the passing of the Indian frontier it became evident that the government would not need all of this land for a military reserve and squatters settled upon it, at first with the consent of the military authorities at Fort Snelling. In 1838 many of the squatters were forced to move to the east side of the river where they "squatted" again on the reservation lands. Considerable friction existed, however, between them and the military authorities, chiefly because of the ease with which soldiers at Fort Snelling could secure liquor, and, in 1840 , the squatters were driven off the lands east of the river and their cabins were destroyed. They then moved down the river beyond the limits of the reservation and begun the settlement which in time became St. Paul.

As early as November, 1849, the territorial legislature passed a joint resolution calling upon Sibley to use his influence with the Department to have the reservation confined between the Mississippi and Minnesota rivers and for pre-emption rights in favor of the settlers who had been driven off the reservation lands. ${ }^{20}$ On January 10, 1850, the Secretary of War informed Sibley that the President had directed the sale of

${ }^{20}$ Minnesota Chronicle, March $30,1850$. 
such part of the reserve as was no longer required for the use of the post. ${ }^{21}$ The bill to reduce and define the boundaries of the reserve was introduced in the Senate by Douglas, at Sibley's request, and passed the Senate without difficulty, but called forth considerable debate in the House. The principal objection offered was that the War Department had not approved the reduction of the military reserve and some members were afraid that in a short time it would be necessary to buy back the land at a much higher price than it would be sold for. Other members objected to the provision granting pre-emption rights to the squatters who had settled on the lands. In reply to a question by Wentworth, of Illinois, Sibley stated that perhaps not more than ten or twelve persons would be benefitted by the pre-emption provision in the bill and he admitted that he himself was one of the squatters, since his house at Mendota which he had built fifteen years previously was on the land which it was now proposed to open up. He stated, however, that he asked no favors not granted to others. After a long debate Sibley moved to refer the bill to the Committee on Military Affairs since, as he said, he "wished nothing done in reference to this subject which would not bear the strictest scrutiny." ${ }_{22}$ When the people in Minnesota thought that the bill with the pre-emption provision would be passed by Congress many who were not entitled to pre-emption rights hastened to set up claims. ${ }^{23}$ Sibley was in a very awkward position. It had been the intention of the legislature in its memorial that pre-emption should apply to those squatters who had been driven off the reserve, but the way the bill was drawn these men would not be benefitted. Sibley feared, therefore, that he would be accused of looking after his personal interests and those of the fur company and neglecting the interests of the other squatters. ${ }^{24}$

${ }^{21}$ This probably referred to lands west of the Mississippi and on the east side of that river, south of the St. Peters river. Minnesota Pioneer, Feb. 20, 1850.

${ }^{2}$ Congressional Globe, 31 Cong. 2 Sess., 433-443.

${ }^{2}$ H. A. Lambert to Sibley, March 18,1850 .

" Sibley to Ramsey, May 22, 1850 , in Ramsey Papers. This discussion was brought up against Sibley during the campaign of 1850 and was referred to in the "Hal Squibble" broadside. See Chapter V, above. 
The bill did not become a law, however, and other petitions were sent to Congress upon the subject. In 1852 the reserve was finally reduced and, through Land Claim Associations, the settlers secured the lands at the minimum price $\$ 1.25$ per acre. ${ }^{25}$

25 Folwell, Minnesota the North Star State, I29-I 30. 


\section{CHAPTER VII}

\section{THE INDIAN PROBLEM ON THE FRONTIER}

(a) The Indian Policy of the United States Government

The presence of the Indian on the frontier was a problem that confronted the settlers in all sections of the country. A discussion of the various phases of the question as it presented itself to the pioneers of Minnesota will be typical, therefore, of what happened over and over again in the conquest and settlement of the continent. Indian traders went everywhere and liquor frequently or usually went with them. The advance of white settlement meant a shifting of the various Indian tribes from one location to another. The presence of valuable timber or minerals on lands not yet ceded to the United States by the Indians was also a frequent cause of trouble between the races. Finally, the pressure of settlement on the Indian frontier became so great that new treaties had to be negotiated with the Indian tribes for their removal in order to open up new areas of settlement to the whites. The pioneers of Minnesota had to contend with the Indian problem in all of these phases.

It is a well known fact that in the contact of races the inferior race takes on the vices before it takes on the virtues of the superior race. The Indians were not constitutionally able to resist the evil influences of the liquor traffic and many traders, in spite of laws to the contrary, took supplies of this commodity into the Indian country as a necessary part of their supply of goods for trade with the red men, justifying themselves in their own eyes, if any such justification was necessary, by the fact that other traders would do the same and that the Indians would demand the "fire-water" and would trade only where it could be obtained. 
Sibley was always opposed to the use of liquor in the Indian trade and one of his first acts after reaching Washington in December, I849, as the first elected delegate from Minnesota Territory, was to address a communication to the Secretary of State informing him of the fact that the Hudson Bay Company was regularly furnishing liquor to the Indian tribes within the limits of the United States and asking if friendly remonstrance could not be lodged with the British Government against the practice. He stated that the situation was not only demoralizing to the Indians, but was threatening the peace of the northwestern frontier. The Secretary of State replied that the United States Minister in London had been directed to bring the matter to the attention of the British Government and to remonstrate against the practice. ${ }^{1}$

The Hudson Bay Company was not the only means, however, by which liquor reached the Indians of Minnesota. The Act of March 3, 1847, made it unlawful to take liquor within the boundaries of the Indian country, but it did not prevent its sale to the Indians just outside of those boundaries. Also, as has been stated, some traders took it into the Indian country in defiance of law. The result was that Indians could secure it without difficulty, and that much drunkenness was in evidence. Sibley attempted to protect the Indians against this demoralization, but the evil could not be entirely eradicated.2

The one great question on which Sibley was qualified to speak in Congress was the Indian policy of the United States government. He not only knew the workings of that policy thoroughly, but he knew the Indian and the Indian question more thoroughly than any man in Congress at that time. Sibley had lived on the frontier for fifteen years; he had not only traded with the Indians, but he had lived among them and

${ }^{1}$ Clayton to Sibley, Dec. 11,1849 , published in Minnesota Chronicle, Jan. 8, $185^{\circ}$.

2 J. E. Fletcher to Sibley, Jan. 19, 1849, and H. A. Lambert to Sibley, Feb. 6, 1849 . Also Minnesota Chronicle, Jan. 19, 1950. Also Congressional Globe, 31 Congress, 1 Sess. 295. There is a letter to Sibley from Lewis Cass, Secretary of War, dated Nov. 5,1834 , which indicates Sibley's early attitude: "I am glad to learn the determination of the company you are associated with to comply with the law prohibiting the sale of ardent spirits to the Indians." 
knew their language, their character, their possibilities, and their condition under the existing policy of the government. He was convinced that the methods of the United States government in dealing with the Indians was radically wrong and he made many eloquent appeals in behalf of the red man while he was in Congress.

In an unfinished manuscript left among his papers (undated but probably written about this time) Sibley enumerated six defects of the government's Indian policy. One effect of that policy was to cause strife and rivalry among the Indians themselves. Sibley believed that conditions among the native tribes were better before the government exercised any control over them than it was at any subsequent time. "The tribes which have had dealings with the government," he wrote, "are much more miserable than the bands further removed who subsist entirely by the chase. With them the authority of the chiefs is much better established, and, living on the most intimate and friendly terms with their traders, they are furnished with ammunition and clothing in exchange for the skins of wild animals, and, their few wants thus supplied, they are free from cares and are comparatively happy. The instant the arm of their 'Great Father' is extended to them for the purpose of acquiring their lands their miseries commence. Parties are forthwith formed in the state and the simple savage is converted into an intrignant for place and an aspirant for the honor of wearing a larger medal, the gift of the Government, than his neighbor." Sibley believed that the policy of concentrating the tribes in Indian Territory was wrong because it might lead to the formation of a powerful confederacy there and thus endanger that section of the frontier. He also thought that it was unfair to take the Indians from their northern hunting grounds to the southwestern part of the United States where climatic conditions were so different. The stipulations in the various Indian treaties, Sibley asserted, were not carried out in good faith. Oral promises were frequently made by the Commissioners who negotiated the treaties and, since these 
provisions were not incorporated into the treaties, the Indian Agents who subsequently came among the Indians knew nothing about them and trouble inevitable followed. The Indian Agents usually did not understand the Indians and were consequently without influence among them. "The Agents being for the most part selected from among brawling partisans," he wrote, "rather than for any peculiar fitness for office and, ignorant of Indian character, to avoid trouble to themselves in the discharge of their official duties, receive the chiefs \& principal men who visit them abruptly and cavalierly and have not the patience to hear and faithfully report their complaint to the Department. The writer has witnessed this in numberless instances as well as the mortification and resentment felt \& expressed by the slighted party after such reception." Another defect of the Indian policy was in hiring inefficient interpreters. Sibley believed that this position should pay enough salary to attract men of intelligence and education. Under the system then existing the office was "necessarily conferred upon men who either from ignorance or indolence cannot or will not earn their subsistence elsewhere. The Agents are made to say to the Indians what they never dreamed of and vice versa, and thus the relations of the Government are daily jeopardised under the operation of this 'penny wise and pound foolish' system." Finally, crimes committed by Indians should be certainly and promptly punished. Sibley stated that the policy of Great Britian was much better in this respect than that of the United States. He cited an instance while the British were still in charge at Prairie du Chien in 1813 when two Canadians had been murdered by the Indians. The murderers were immediately captured, tried by 'a drum-head martial,' and executed the same evening in the presence of several members of the tribe. "No more murders were committed," Sibley wrote, "while the British held the country." "After all," he continued, "the secret of the attachment of the northwestern Indians to the English government may be traced to this spirit of promptness. Promises when made were reli- 
giously kept, and threats when uttered invariably carried into effect. If this plan was pursued and the other evils corrected which have been noticed above, I assert without fear of contradiction that the Indians everywhere would become as much attached to our Government as they ever were to the British, and no further fears need be entertained that our frontier will ever have to undergo the horrors of a savage war."'3

Sibley's proposed solution of the Indian problem foreshadows by many years the legislation when the United States finally decided to abandon the policy of regarding the Indian tribes as "nations" with whom treaties would be negotiated," and substituted the plan of civilizing and educating them and helping them to become self-supporting. As a final result of the system then existing, Sibley saw only the eventual disappearance of the American Indian from the face of the earth. In a letter to Senator H. S. Foote he stated what he believed to be the inevitable consequences of the Indian policy. "The Indian is here in his forest home, hitherto secure from the intrusion of the pale faces; but the advancing tide of civilization warns him that ere long he must yield up his title to this fair domain, and seek another and a strange dwelling place. It is a melancholy reflection that the large and warlike tribes of Sioux and Chippewas who now own full nine-tenths of the soil of Minnesota must soon be subjected to the operation of the same causes that have swept their Eastern brethern from the earth unless an entirely different policy is pursued by the Government towards them. If they were brought under the influence and restraint of our benign laws, and some hope extended to them that education and a course of moral training would, at some future period hereafter, entitle them to be

'Sibley introduced bills to bring about reform in the Indian policy, but without success. The fact that Sibley was a fur trader and was conCongressional Globe, 31 Cong. 1 Sess. 295. The fact that Sibley was a fur trader and was to look with nected with a large fur company may have caused some minbers of Congre

some suspicion upon his proposed reforms in the relations with the Indians.

'The Indian tribes were denationalized by the Act of March 3, 1871. 
placed upon an equality, socially and politically, with the whites, much good would be the result." ${ }^{5}$

Sibley attempted to have the bill for the census of 1850 so amended as to have an enumeration made of all the Indian tribes. He believed that if such an enumeration had been made at the time of each census it would have shown a diminution of from 20,000 to 30,000 Indians each census and would have brought about an investigation of the cause of the decrease in the Indian population. He believed that the decrease and "the wretched and forlorn condition of the remaining tribes is to be ascribed entirely to the unsympathetic and cruel policy of the Government towards them, and to no other cause." In that session of Congress made famous by the great debates over slavery Sibley made the following earnest plea for the Indian: "Sir, during this session we have heard these Halls ring with elequent denunciations of the oppressor-with expressions of sympathy for the down-trodden millions of other lands; while gentlemen seem not to be aware that there exists under the Government of this Republic, a species of grinding and intolerable oppression, of which the Indian tribes are the victims, compared with which the worst form of human bondage now existing in any Christian State may be regarded as a comfort and a blessing.",

Upon reading Sibley's speech on the census bill, Ramsey Crooks, president of the American Fur Company, immediately wrote to Sibley congratulating him and expressing the hope that he would "completely expose" the whole Indian policy of the government. ${ }^{7}$ This Sibley did in an able and eloquent speech in Congress on August 2, $18500^{8}$ He stated that while the Commissioner of Indian Affairs made annual reports not

\footnotetext{
'Sibley to Foote, Feb. 15,1850 , published in the Washington Union and also in Minnesola
Historical Collections, $\mathrm{1}: 20-2 \mathrm{1}$.

7 Congressional Globe, 31 Cong, 1 Sess. $855-8$ 56.

fications of this truly man who has ever been in Congress that fully understands the ramidevelopments that will astentious question and you owe it to the country to put on record Sibley, May 7, 1850 .

Congressional Globe, 31 Cong. I Sess. 1 506-1508.
} 
one-tenth of the members of either house of Congress ever took the trouble to read them, and that the Committee on Indian Affairs never pretended to do more than act upon business brought before it. There was no real investigation of conditions and no constructive policy in dealing with the problem. Sibley believed that more attention had formerly been paid to Indian affairs and stated that several "plans were originated to meliorate the condition of the Indian race," but that no systematic effort had ever been made "to civilize them or to prepare them for admission into the great American society of freemen." Individuals had tried to evangelize them, but with little success. Sibley contrasted our treatment of the Indians with the policies of the Greeks, Romans, and Franks in dealing with conquered peoples and with the British policy in India. "It remained for those Anglo-Saxons," he said, "who fled to this New World to escape persecution at home, and for their descendants, boastful as they ever are and have ever been of their philanthropy and their religion-it remained for them, I say, to show to the world that while they wrested from the red man the soil which gave him birth, they neither incorporated him into their community as a member, nor bestowed upon him any of those beneficent appliances which were necessary to preserve him and raise him to a level with themselves. From the days of the Pilgrim Fathers to the present time, there is the same sad story to be repeated of grievous wrongs inflicted upon this unhappy race." He maintained that the policy of removing the Indians to reservations west of the Mississippi had had disastrous effects upon "the bands of wild and noble savages who roam the western prairies," since the Indians who were removed were "reeking with the vices but possessed none of the virtues of the whites." If the government had elevated the Indians before their removal westward their removal might then have had the opposite effect. The result of the government's policy was that most of the Indians who had been removed were "secret and avowed enemies of the United States." The fact that the Indians were powerless to redress 
their grievances should compel the government to perform its obligations. "I will venture to assert," he said, "that not one in ten of the treaties made will be found to have been carried out in good faith." Such treatment of the Indians could only make enemies of them, and this feeling of hostility was transmitted to the tribes with whom these Indians came in contact in the West. This was the cause of our Indian wars, Sibley said, and the government would continue to have trouble as long as it followed the existing policy in dealing with the Indians.

To civilize the Indian, Sibley argued, his ambition must first be stimulated; he must be given hope; his confidence must be won; and he must be convinced that the pledged faith of the government is binding. The first step in the improvement of the Indian must be to extend to him the protection of the law. Such a provision "has for its object the security of life and property among the Indians themselves, to protect the industrially disposed against the system of communism by which they are oppressed." They should then be given lands without power of alienation, conditioned upon living and cultivating the land." "Give the Indian a home and you will have done much to redeem him. You thereby begin the process of denationalization, and the end will be his incorporation into the American family. Meanwhile bestow upon him civil privileges, withholding political rights until he is sufficiently advanced to appreciate their enjoyment. Establish manual-labor schools for the education of his children in the useful arts, and in the English language, and afford him at the same time the blessings of religious instruction. . . . Adopt these incipient measures and thus prepare the way for the reception of the Indian as an equal into your community. . . But, Mr. Chairman, I remark in conclusion that if anything is to be done it must be done now. The busy hum of civilized communities is already heard far beyond the mighty Mississippi.

'Congressional Globe, 30 Cong. 2 Sess. $448 ; 3^{1}$ Cong. 2 Sess. 18, 22. 
... Your pioneers are encircling the last home of the red man, as with a wall of fire. Their encroachments are perceptible in the restlessness and beligerent demonstrations of the powerful bands who inhabit your remote western plains. You must approach these with terms of conciliation and of real friendship, or you must soon suffer the consequences of a bloody and remorseless Indian war. . . . The time is not far distant when, pent in and suffering from want, a Philip or a Tecumseh will arise to band them together for a last and desperate onset upon their white foes. What then will avail the handful of soldiers stationed to guard the frontier? Sir, they and your entire western settlements will be swept away as with a besom of destruction. We know that the struggle in such case would be unavailing on the part of the Indians and must necessarily end in their extermination. . . . Well might the eloquent Sevier, whose voice is now silenced in death, thus appeal to the Senate in behalf of the Indian tribes in 1839 . Said he: "Let us remember the kind and hospitable reception of our ancestors by the natives of the country, a reception which has been perpetuated in carved figures in the walls of the Rotunda of this capitol; and in remembering these things, let us this day step forward and do something for our wretched dependents, worthy of a great, merciful, and generous people."

Sibley's eloquent words in behalf of the Indian were not heeded and Mason, of Kentucky, turned the discussion from the Indian to the slavery question. "Nature and Nature's God," said he, "made the white man, the red man, and the black man; and when gentlemen undertook to make them equal, they undertake an impossible task. Our friends in the free States from the North have manifested as great a desire to elevate the condition of the African race- the black manas my friend from Minnesota has shown to elevate the condition of the red man." It was hardly to be expected that the session of Congress that produced the Compromise of 1850 over the slavery question would take favorable action in behalf of the oppressed Indian. The system was not changed and the con- 
sequences which Sibley had so accurately foretold came in the great Sioux uprising of 1862 , and Sibley himself was the man to whom the Minnesota pioneers turned in their hour of danger to save them from the horrors of another Indian war.

\section{(B) The Rice Contract}

The contract which Henry M. Rice made with Orlando Brown, Commissioner of Indian Affairs, in 1850 , for the removal of the Winnebago Indians to their new reservation in northern Minnesota is important, not only as a test of strength or "pull" between Sibley and Rice, but also as an illustration of one phase of the government's policy in dealing with the Indians.

The Winnebagoes belonged to the Siouan linguistic family and had lived in the region west of Green Bay at least since I634 when Nicollet made them known to history. Together with the Sauk and Foxes and the Menominees they controlled the Fox-Wisconsin route to the West, and thus exercised considerable influence in determining the course of trade of the upper Mississippi. By the Treaty of Prairie du Chien they ceded all their lands south of the Fox and Wisconsin rivers in return for a reservation west of the Mississippi. By the Treaty of 1837 they gave up all claims to lands east of the Mississippi and in 1846 removed to the "neutral ground" in Iowa Territory. The advance of settlement by the whites made necessary another treaty with them, and in 1846 they surrendered their reservation for another one to be located north of the Minnesota river in what was soon to be Minnesota Territory. ${ }^{10}$ This reservation was selected for them by Henry M. Rice, who had considerable influence among them, and they were removed to the Crow Wing reservation in 1848 , Rice aiding in their removal. It had been the hope of the Indian Department that the Winnebagoes would form a buffer state between the Chippewas and the Sioux, who had been traditional enemies, but this plan did not succeed. The Winnebagoes were

${ }^{10} \mathrm{~J}$. Owen Dorsey and Paul Radin, "The Winnebagoes," in Bureau of American Eshnology Bulletin, 30, Part 2, 958-59. 
dissatisfied even before they reached Crow Wing, and liked it still less after they reached there. As a consequence, they soon began to scatter, some of them wandering off towards the Dakota region. Complaints soon came to the authorities regarding the depredations committed by these roving bands. Orlando Brown, Commissioner of Indian Affairs, wrote to the Secretay of War, G. W. Crawford, stating that the department had been petitioned regarding roving bands of Pottawattamie, Winnebago, and Fox Indians, and asking that the commanding officer at the nearest military post be ordered to inquire into the complaints and compel the Indians to return to their reservations. The Adjutant General wrote to General Clark at St. Louis to have the commanding officer at Fort Snelling remove the intruders. ${ }^{11}$

The Indians seem to have been doing little real harm in the regions where they were roving about except where they were encouraged by lawless white men to make depredations on the frontier settlements. Chief Justice Williams, of Iowa, denounced these "unprincipled outlawed white men" in a letter to Major Murphy, Indian Agent at St. Peters. "When it may be to the advantage of these lawless white vagrants," he wrote, "they will assail and Rob the Indians and charge their acts upon innocent settlers and good citizens and then they will Rob and steal from the settlers and charge their acts upon the Indians. These white savages have great influence with the Indians and as it suits their purpose to keep up this state of things they advise and aid the Indians in rebellion against the Government and its agents. For shrewdness in villany and capacity in judging of the means possessed by the officers of the Government for the management of the Indians these men cannot be surpassed." 12

Major Woods was sent out from Fort Snelling in September, 1849 , on an exploring expedition through Iowa to investigate

"Copies of these letters of August 22 and 23, 1849, are in the Sibley Papers. A copy of one of the petitions signed by forty people, under date of Feb. 28,1850 , is also in the Sibley Papers.

${ }^{12}$ Williams to Murphy, Aug. 31 , 1849 , in Sibley Papers. 
the conditions. He found that the reports were greatly exaggerated and that the Indians were doing little real harm. "The frontier seems to be much disturbed," he reported, "by the presence of horse thieves \& plunderers of every description to rid themselves of whom the law-abiding portion of the community, as they consider themselves, have formed into a body, sworn to clear or exterminate from the Frontier this numerous \& troublesome association of marauders. In execution of which design these regulators have already hung to trees several men \& shot more, without the troublesome \& uncertain resort to Judges \& Jurymen. This policy may drive these offenders back among the Indians with whom they unite $\&$ probably return with redoubled fury \& power to carry out their nefarious pursuits. The settlers are much exasperated \& their excited visions see suspicious conduct, perhaps where there is none. To be rated as a 'horse thief' it is sufficient for a man to "wear good clothes, ride a good horse, have some money, \& not work.' These are the unfailing prognostics of dishonesty.'

In regard to the nature of the injury done by the Indians, Major Woods found that they "do but little \& aim to do less positive mischief, but frighten back new settlers, who not being accustomed to Indians are unwilling to go into a country where they are. . . . That the presence of these bands retards the settlements is doubtlessly true as it is the general \& greatest grievance complained of." Other complaints that he had heard of were that the Indians destroyed timber, killed the game, destroyed surveyors' land-marks, and that they were dangerous men when they were "in liquor." Too much attention should not be paid to petitions coming from the frontier, Woods stated, because petitions were easily gotten up and were "signed readily without the signers even inquiring into the nature of them." It was said "that there were two classes of citizens on the frontier, one sells liquor to the Indians watered \& the other without water. The latter class are sometimes outdone by the former \& make complaints." Major Woods reported that there were about 400 to 600 Pottawattomies, Foxes, and Winnebagoes on 
the frontier in Iowa and that most of the Winnebagoes had never been at the Crow Wing reservation. ${ }^{13}$

When Major Woods returned to Fort Snelling with his report, the commanding officer, Lieutenant Colonel Loomis, reported to his superior at St. Louis that the Indians "seem to be so peacefully inclined and in general give so little trouble and withal do so little damage that I do not think a winter campaign called for." ${ }^{14}$ He recommended that dragoons or mounted infantry be sent in the spring to remove the Indians to their reservation. In conformity with this recommendation orders were issued, February 28, 1850, from St. Louis for Major Woods to take a company of the First Dragoons stationed at Fort Gaines and two companies of infantry from Fort Snelling and remove the Indians from Iowa. The dragoons were ordered to proceed from Fort Gaines to Fort Snelling on April 9, I850. This plan was in process of execution, therefore, when the authorities on the frontier learned of the contract which Rice had made with the Commissioner of Indian Affairs.

Rice wrote from Washington to Governor Ramsey, March I9, I850, informing him that he had on that day made an offer to the Indian Department to remove the Winnebagoes, but that the matter would be referred to Ramsey as Superintendent of Indians in Minnesota Territory, before being definitely acted upon. Rice hoped that Ramsey would give a favorable reply to the proposition, and he asked Ramsey to keep the matter secret because he feared that efforts would be made by his enemies in Minnesota, if they heard of the contract, to cause the Indians to disperse and thus cause Rice to lose heavily on the deal. ${ }^{15}$

Sibley heard that there was some such move on foot and wrote to Ramsey about it on March 22, 1850. "The latest move $\&$ joke of the season is the offer of Rice to the Indian

13 Woods kept a diary of his trip and the manuscript is in the Sibley Papers.

"Loomis to Buell, Oct. 23, 1849, a copy of which is in the Sibley Papers.

is Rice to Ramsey, Mar. 19, 1850, in Ramsey Papers. The matter was never referred to

Ramsey as Rice thought it would be, and Ramsey did not favor such a procedure. 
Office to remove the Winnebagoes back to their home at $\$ 75$ per head men, women, \& children. I am assured confidentially that the scheme was pressed upon the Commissioner seriatim by Cochrane the clerk, but a quietus was put upon it by D. D. Mitchell, who told the former if such a plan was adopted he would protest openly against it. Did you ever hear of such gross impudence as is manifested in this proposition?"

The contract was entered into, on April I3, 1850.16 Rice bound himself to collect the scattered Winnebagoes and remove them to Crow Wing during the year I 850 , to furnish the Indians "with ample subsistence of a suitable and acceptable kind from the time they shall be collected in parties or otherwise for removal, until their arrival in their aforsaid country." Tents, cooking utensels, blankets, shoes, and other articles of a like nature were to be furnished as well as food. Rice was also to have crops planted and cultivated before the arrival of the Indians at Crow Wing. In return for this service, Rice was to receive $\$ 70$ per head for those Indians who had never gone to Crow Wing or who had left that reservation with the intention of not returning to it and whom Rice should succeed in getting back to the reservation. It was specifically stated that it was not to apply to and payment be made for the second removal in case some of the Indians whom Rice took back in $185^{\circ}$ should thereafter leave the reservation again. Rice was to furnish Governor Ramsey with "a correct list or roll of all the said Indians who reached and passed St. Paul," which list Ramsey was to verify and forward to the Commissioner of Indian Affairs and was to be made the basis of payment under the contract. ${ }^{17}$

Sibley had not been consulted by the Commissioner and he first heard of the contract on April 18. His consternation may

\footnotetext{
${ }^{16}$ The contract along with other documents relating to it was published in the Chrovicle and Register, July 8,1850 .

Olmstead was about the only been appointed by Ramsey to check the roll as filed by Rice. except Rice, to really renly man who was well enough acquainted with the Winnebagoes, Olmstead in on the contract withe and check the Indians as they passed St. Paul. Rice took to Sibley, June 3,1850 .
} 
well be imagined. On the following day he wrote his "official protest" which he filed with the Commissioner, and asked that the contract be annulled for the following reasons: "First, it is evident that the Department has been grossly deceived by Mr. Rice as to the number of Indians absent from their own lands, and his ability to perform what he has undertaken. I have received information which leads me to believe that fully one half of the whole tribe are absent from the spot which the Government had set apart for their dwelling place. Consequently when Mr. Rice induced the Department to enter into a contract with him upon his representation that there were fully a thousand or twelve hundred he practiced a deception upon it which fully exonorates it from any obligation to carry out the contract." In the second place, Sibley claimed that the amount to be paid was at least three times what it should be if any contract was to be made. Also the contract reflected upon the Indian officials, including Governor Ramsey, and would bring upon them "the contempt of the Indians." Sibley believed that the plan already in process of execution on the frontier was the proper method to pursue, not only cheaper, but of more lasting effects. "Finally," he said, "I take the liberty of stating my opinion that the present scheme of Mr. Rice is derogatory to the dignity of the Government, which should be able to manage a tribe of vagabond Indians without counting on the support and supposed influence of any individual in carrying out its designs. Why I was not consulted. . . I I am at a loss to decide. I was present at the Indian office for more than two hours on the $13^{\text {th }}$ inst., the day on which the contract was signed and, although the subject of the removal of the Winnebagoes was discussed and Governor Ramsey's official dispatch read to me by yourself in the presence of Colonel Mitchell, Mr. Rice also being present in the office, I did not receive a single intimation that a measure of so much importance as the contract alluded to was to be consumated, or I should have protested against it on the spot. This apparent studied concealment I deem to be on my part a 
just subject of complaint." Sibley stated that he was satisfied "that other persons than Mr. Rice, who I learn were active in urging this measure upon the Department, are more or less pecuniarily interested in the success of his contract."

On April 20, Sibley wrote to Ramsey giving his opinion as to the inside working of the Indian Department by which Rice was able to get such a contract. "This iniquitous scheme," he wrote, "was concocted while I was confined to my room some twenty days with inflamation of the eye. . . I have no doubt Cochrane persuaded Brown to sign the contract, and I firmly believe him to be one of the worthy trio who are to profit by the arrangement. I told Brown that I would have undertaken the service for $\$ 20$ perhead, if disposed to meddle with that sort of business, but I really believed the system of private contracts for such objects to be dishonorable to the Government. . . Between ourselves, Brown is utterly out of his element in the Indian Office. He has neither industry nor any knowledge of Indian Affairs, and is very easily duped. As for Cochrane, I have no faith in him."1s

Colonel A. M. Mitchell, the Whig Marshall of Minnesota Territory, who was with Rice in Washington and who was to be a candidate for delegate against Sibley during the summer of that same year, wrote to Ramsey on April 23 that Sibley had filed his "official protest," but that it would be disregarded. "I have thought," he wrote, "that I would inform you that the government pays no attention to his Protest, but look upon it as consumate presumption. . . . It is true that Mr. S. was not consulted because they supposed his opinions of no importance and could or would not shed any light on the subject."

Brown replied to Sibley's protest on April 25, 1850, and said that Sibley was not consulted before the contract was made because the matter was to affect Iowa and Wisconsin and that Minnesota had no cause of complaint. He affirmed that there was no cause for concealment and no reason for wishing to

1s Cochrane was a clerk in Brown's office. 
keep Sibley ignorant of it. Brown believed that the Indians should be removed without the use of dragoons. The contract was, he said, "in design one of humanity - such as has been too seldom practiced against the Indians." Brown stated that he had conferred with Senator Jones, of Iowa, Colonel Mitchell, and others, and that they had thought the price not exorbitant. "I was therefore upon such representations warranted in contracting with him. Indeed, the impression made by these gentlemen was that he was the only man whose influence with the Indians was such as to enable him to effect what was proposed." Brown insisted that the Indian Office had never distrusted Governor Ramsey and meant nothing disrespectful to him by taking the matter out of his hands and giving it to Rice. "The contract," he concluded, "whether wise or not is a binding contract, and not subject to repeal, even if I desired to do so, which I do not."

Orlando Brown seems to have been a well-meaning Commissioner of Indian Affairs, but he was a man who did not know the details of the business which he was supposed to direct. $\mathrm{He}$ seems also to have been easily influenced by his subordinates, some of whom were doubtless interested in some way in getting the contract for Rice. The whole affair would probably be called a case of "graft" in later terminology, but no suspicion was ever attached to Orlando Brown in this respect. ${ }^{10}$ The worst that can be said of him is that he was led by men whom he trusted, but who were not entirely reliable, to make the contract.

The newspapers of Minnesota did not oppose the contract when its existence first became known. The Pioneer of May 9, 1850, announced it in the following words: "Mr. H. M. Rice, of St. Paul, has taken a contract from the Government to remove the Winnebago Indians back again to their proper

An idea of the reasonableness of the price paid to Rice may be formed by comparing it with a contract which Major Woods made with A. D. Stephens for the removal of the Fox and other tribes in Iowa "to their homes west of the Missouri." Stephens was to be paid $83-50$ for each male and fernale transported, with an allowance of 8500 for provisions. 
limits near Crow Wing, at so much per head. This will save much expense of equipping and marching troops." The Chronicle and Register of May I I, I850, said: "Mr. Rice has the business talent and energy to accomplish it, and we are told by those better acquainted than ourselves with such matters, that the compensation is very liberal." Dr. Potts wrote to Sibley on June I, I850, giving another view of it. He said that a copy of the St. Louis Union of May 25, containing a long article on the contract and denouncing the Whig administration as a "rotten concern" had caused Minnesota Whigs who did not like the contract to feel called upon to defend the administration and hence say little about it. ${ }^{20}$ Others said that it would have been so much the better if Rice got $\$ 1,000$ per head instead of $\$ 70$, since he would leave the money in the country while if the fur company had gotten the contract the money would have been taken out of the Territory. Such individuals said that "all the fuss has been raised because the Fur Company did not get it." The Chronicle and Register of June 10, 1850, said that the matter resolved itself into a fight between Pierre Choteau \& Company and Rice-“" a personal quarrel between two rival parties of Indian traders-one party wanted the contract-the other got it."

Sibley honestly believed that a fraud was being committed against the Government and that the price paid Rice was far greater than it should have been. He would have opposed any such contract with any one, but he was, of course, determined against this one, since the beneficiary was his most bitter personal and political enemy. He did everything in his power to have the contract anulled, even taking the matter to the President, ${ }^{21}$ and, when that failed, he caused a Congressional investigation to be made. This investigation dragged on during most of the summer of 1850 and, in the meantime, Brown resigned his office and was succeeded by Luke Lea. ${ }^{22}$ In the end,

\footnotetext{
20 The article in the St. Louis Union denouncing the contract as gross fraud and condemning the administration for making it was no doubt inspired by the Choteau fur company.

at Sibley to Ramsey, May 18, 1850 , in Ramsey Papers.

2 Sibley to Ramsey, May 30,1850 , in Ramsey Papers.
} 
the Committee reported against rescinding the contract and Sibley failed in his struggle to prevent Rice from carrying it out. "I suppose Rice will claim a victory over me," Sibley wrote to Ramsey on June 26, "but he has in reality had nothing to do with the result except so far as his friend Jones operated to throw cold water upon the democratic members of the Committee, which I must do him the justice to say he did most actively." Sibley had been at a disadvantage in not using private letters from Ramsey and others as evidence, without having their permission to do so, and by not having time to get additional evidence from Minnesota. Morever, the burden of proof had been upon him. He was greatly disappointed at the outcome, but two points gave him some encouragement. Orlando Brown was succeeded by a man in whom he had the utmost confidence, and the whole affair convinced the authorities at Washington that greater reliance should be placed on Governor Ramsey as ex-officio Superintendent of Indians in Minnesota. ${ }^{23}$ The total amount paid under the contract was $\$ 24,330.72 .^{24}$ The fact that the amount was no larger seems to have been a reason why the contract was not rescinded after the matter had been so vigorously protested by Sibley. The point which hurt Sibley most was the way it was interpreted in Minnesota as a test of political strength between himself and Rice. ${ }^{25}$

\section{(C) The Sioux Treaties of 1851}

With the title of nine-tenths of the soil of Minnesota still in the hands of the Indians, it was evident that other treaties with them were necessary if the young territory was to have even normal growth. ${ }^{26}$ Consequently, the pioneers began to demand treaties with the Sioux and Chippewas almost as soon as Minnesota Territory was organized. ${ }^{27}$ Goodhue, in the

${ }^{24}$ Sibley to Ramsey, June 20 and July 26,1850 , in Ramsey Papers.

" Congressional Globe, 32 Cong. 2 Sess. 1080.

is Folwell, Minnesota, 105.

${ }^{*}$ The early settlers recognized that the land west of the Mississippi must be acquired or Minnesota would remain "a dwarfed and blighted Territory for years." Pioneer, Dec. 25, 1851 .

${ }^{n}$ Ramsey asked the first territorial legislature to memorialize Congress for a treaty with the Sioux and this was done. Fournal of the Council of Minnesota Territory, 1849, 110. 
Pioneer, reflected the typical attitude of the settlers when he stated that the Sioux would have to go and "the sooner the better." ${ }_{28}$ The Indians themselves were ready to treat in I $85 \mathrm{I}$ because the growing scarcity of game was causing much hardship and suffering among them and they were anxious to get annuities from the government. The traders were anxious for a treaty because they recognized that the fur traders' frontier was passing from Minnesota and they were anxious to have a settlement of their Indian credits which, because of the destitution of the Indians, were growing larger and larger, and the prospects of settlement by the Indians themselves was growing less. ${ }^{29}$ Things were favorable, therefore, for the negotiation of other treaties and this was accomplished in $185 \mathrm{I}$.

The negotiation of an Indian treaty was a great event in frontier history and there was a general scramble among the traders to get "the spoils." The influence of the traders and half-breeds had to be taken into consideration if any success was to come from the negotiations, for if these two influences were thrown against the making of a treaty the commissioners were doomed to failure. This raises the whole question of the justice of the traders' claims.

Since practically all of the Indian trade was carried on by credit extended to the Indians in the fall with the promise of payment in the spring when the winter's supply of furs had been brought in, it is an unquestionable fact that many of the traders' accounts against the Indians were not paid in full. As has been shown in a previous chapter, certain of these accounts were carried year after year on the books of the American Fur Company, and the same was probably true of other traders. On the other hand, it has also been shown that the goods were sold to the Indians at a profit of $75 \%$ to $100 \%$ or even higher. As with modern business men doing a credit business, the selling

${ }^{28}$ Pioneer, Feb. 13, 1850. Franklin Steele wrote to Sibley that "the population of Minnesota will not remain cooped up between the St. Croix and the Mississippi and will push west in spite of troops, Indians, or any other obstacles," Steele to Sibley, Feb. 18, 1851.

"McLeod, a trader, wrote to Sibley. April Steele to Sibley, Feb. 18, 1851. be between $\$ 4,000$ and $\$ 5,000$ and that the Indians w w 1 , that his credits for that year would 
price of goods was doubtless placed high partly to cover possible loss on bad accounts. There is no question that the trader assumed considerable risk, since he bought his goods on credit and, in turn, extended credit to the Indians, and had to depend for the sale of his furs on a future market where prices could not be definitely determined. For these reasons he could be justified, according to modern business methods, in charging a higher price for his goods than if the transaction had been on a cash basis. When an Indian treaty was to be negotiated, however, all of these old accounts against individual Indians, many of them running back for several years, were presented by the traders as a charge against the whole tribe. Some of these accounts were no doubt accurate and many of them were probably "padded." It will never be possible to analyze these accounts and determine with even an approximate accuracy just how much the Indians were defrauded at the making of a treaty. The total of all the claims against the Indians greatly exceeded the amount set aside for the payment of their "just debts," and negotiations among the traders themselves were necessary in order to determine how much of the "spoils" should go to each trader. This would have a tendency to cause dishonest traders to "pad" their accounts with the hope that after the adjustment of claims had been made they would get all that was coming to them. Some claims were not allowed in this adjustment and the dissatisfied traders were ready to oppose the ratification of the treaty, and even to stir up dissatisfaction among the Indians themselves. The halfbreeds also had to be satisfied out of the "spoils," or they would use their influence with the Indians to prevent the success of the negotiations. These two influences must be clearly recognized in order to appreciate the difficulties under which Commissioners worked who carried on the negotiations. ${ }^{30}$ The Sioux

${ }^{20}$ In 1849 Ramsey and Chambers had attempted to negotiate a treaty with the Sioux and attempted to permit them to meet the opposition of these two influences. 
treaties of $185 \mathrm{I}$ were no doubt typical of what happened over and over again in the history of the frontier.

The appointment of Commissioners to negotiate the treaty was all-important from the stand point of the traders. Sibley worked hard and long to get Hugh Tyler appointed Commissioner with Ramsey to negotiate the Sious treaties, but his efforts were in vain. Thompson, of Indiana, was appointed in December, 1850 , in spite of Sibley's opposition to him. Tyler failed to get the appointment, so Sibley wrote to Ramsey, by his "too great impetuosity .. . in repelling the insinuation that we were banded together to compass certain ends of our own." The Indian appropriation bill, however, passed during this session of Congress, contained a provision that all commissioners to negotiate Indian treaties after the passage of the act should be selected from the officers or agents of the Indian Department. In this way it happened that Luke Lea himself became commissioner, jointly with Ramsey, who as Governor was ex-officio Superintendent of Indians in Minnesota, to negotiate the treaties.

Ramsey, in a communication to the Commissioner of Indian Affairs, had expressed the hope, while it was yet thought that Thompson would be one of the commissioners and he the other, that the instructions issued to them should be explicit on the subject of Indian debts to the traders. This called forth the following protest from Sibley: "By the by (remember this is confidential) while I am working for you individually, as well as for the Territory, here, and bringing up all my forces to sustain you, I do not like to have you suggest to the Commr. that you hope he will restrict the Commrs. on the subject of debts in making the treaties above, so that little or no discretion will be left them, as otherwise the traders who control the Indians will 'exact the last penny.' Now I do not believe, in fact know, you did not wish it to be understood as thereby desiring that the just claims should not be paid, but the communication is susceptible of such construction, and the instructions may be so framed as to forbid you to make any allowances. This 
would be in effect not only to commit a gross injustice towards men who impoverished themselves in supplying the Indians, after 20 or 30 years of labor and exposure, but it would necessarily result in the failure of any attempt to treat. . . We ask no aid from the Government but we do ask that the Indians shall not be precluded from paying their just debts if they wish to do so." "It should be bourne in mind," he wrote on another occasion, "that only one division of the Sioux ever paid a cent of their debts, the Mindayuakantons having done so up to I837. The upper bands have never treated hitherto." ${ }^{31}$

Three treaties were negotiated with the Indians of Minnesota in $185 \mathrm{I}$, two with the Sioux and one with the Chippewas, the last named of which was not ratified by the Senate. The negotiations with the upper bands of Sioux, which were taken up first because they were thought to be more favorable to making a treaty, were carried on at Traverse des Sioux. The treaty with the lower Sioux was made later in the same year at Mendota, and the treaty with the Chippewas was negotiated at Pembina. In the treaty of Traverse des Sioux the upper Sioux Indians agreed to give up all their claims to lands east of Red River of the North, Lake Travers, and the Big Sioux River, except a reservation along the Minnesota river, ten miles on each side of the river, from Lake Travers to the Yellow Medicine river. In return for this cession of land, the Indians were to be paid $\$ 1,665,000$. Of this amount, $\$ 1,360,000$ was to be held in trust by the United States and interest at $5 \%$ per annum paid to the Indians for fifty years, which was to be considered "full payment of said balance, principal and interest." It was provided that certain sums should go into the "civilization fund" and the "educational fund" and that the sum of $\$ 275$,000 was to be used for the purpose of paying the expenses of removing the Indians to their new reservation, for their subsistence there during the first year, and to "enable them to settle their affairs and comply with their

"Sibley to Ramsey, Feb. 9, 185r, and March 2r, 185r, in Ramsey Papers. 
present just engagements." This meant, of course, the traders' claims, and was "to be paid to the chiefs in such manner as they hereafter in open council shall request."

As the Indian chiefs signed the treaty, by mark, they were led to another place and asked to sign another document which is known in Minnesota history as the "traders' paper," but which the Indians thought (so they later claimed) was a duplicate copy of the treaty. The most important parts of this document were as follows: "We the undersigned Chiefs, Soldiers and Braves of the Wahpaton \& Sisseton Bands of Sioux Indians, having this day concluded a treaty with Luke Lea and Alexander Ramsey . . . and being desirous to pay our Traders and Half-breeds the sums of money which we acknowledge to be justly due to them, do hereby obligate and bind ourselves, as the representatives of the aforesaid Bands, to pay to the individuals hereinafter designated, the sums of money set opposite their respective names... and as it is specified that said sum shall be paid in such manner as requested by the Chiefs in open council thereafter, we do hereby in open council request and desire that the said sums below specified shall be paid to the persons designated. . . . and for this payment well \& truly to be made we here by solemnly pledge ourselves and the faith of our nation. . . ."

This paper was not read or explained to the Indians at the time of signing it and the evidence is not conclusive that its contents were explained to them at that time. ${ }^{32}$ It is certain, however, that the Indians were told that part of the $\$ 275,000$ was for the purpose of paying their debts to the traders. ${ }^{33}$ Since the Indians signed the traders' papers immediately after signing the treaty, there was no opportunity for an open council unless it ${ }^{22} \mathrm{~J}$. R. Brown and Martin McLeod, two of the traders, both testified before the Com-
mittee that investigated the matter that the paper was explained to the chiefs before they signed
it. Senate Document, it. Senate Document, 61, Pp. 42, 219, 245.

as. R. Riggs, a missionary and a witness to the paper wrote: "I was not present at any meeting of half-breeds and those engaged in the trade held for the purpose of adjusting matters among themselves. . . But everytohere, on all occasions, and at all our meetings with the principal Dakota men. . . I told them plainly, and heard others tell them that the $\$ 275,000$ was intended among other things to enable them to pay their just debts. Riggs to Sibley, Jan. 16, 1852 . 
be considered that they were in open council at the time of the signing of the treaty and in that same open council directed that the money be paid to the traders, thus technically meeting the requirements of the treaty that the money would be paid "in such manner as they hereafter in open council shall request." To an unbiased observer today it looks decidedly like the white man was not dealing fairly with the Indian.

Since the total amount of the claims presented by the traders was greater than the amount of money available to pay the "just debts" of the Indians, it required considerable bargaining among the traders themselves to adjust the claims and find out what the "just debts" really were. The names of the traders to receive payment and the amount to be paid each were not affixed to the traders' paper until the next morning. ${ }^{34}$ In the meantime the traders adjusted the claims among themselves. A committee of three representing the traders, Martin McLeod, Joseph R. Brown, and Louis Roberts, and Sibley, representing the half-breeds, made the adjustment. They did not examine books or compel the traders to make their statements under oath, ${ }^{35}$ and the schedule of claims as affixed to the traders' paper was probably not submitted to the chiefs. ${ }^{36}$ This paper provided that $\$ 209,200$ should go to the traders, $\$ 800$ to S. R. Riggs for the American Board of Missions, and $\$ 40,000$ to the half-breeds, making a total of $\$ 250,000$ out of the $\$ 275,000$. The half-breeds received $\$ 250$ each, some of this money going to the half-breed children of some of the prominent traders.

The treaty with the lower Sioux, made at Mendota, was similar to the treaty of Traverse des Sioux, except the amount of money was different. The traders and half-breeds were provided for and there was a similar adjustment of traders' claims. ${ }^{37}$

${ }^{*}$ Testimony of McLeod before the investigating committee. Senate Doc. 61, 227.

* Ibid, 115,233 .

"Testimony of Sibley: "I do not know that the sums thus apportioned were submitted to the chiefs." Senate Document, 61, p. 219 .

${ }^{n}$ Sibley received $\$ 1,000$ for his half-breed daughter under this treaty and invested it in an Iron Mountain Railroad bond. This account is in his ledger which is in the Minnesota Historical Society library. 
The treaty with the Chippewas was made at Pembina and much the same methods were used there. The traders at that place were anxious to keep outsiders away so that they could get the "spoils." In a letter from Pembina to Fred Sibley, N. W. Kittson stated that they wanted no "loafers" to come to Pembina and that he thought Ramsey "should give the Pembinese a chance at the spoils." ${ }_{38}$ He stated further that if they did come the traders at Pembina would make it so unpleasant for them that they would not want a second trip. On September 23, I85 I, Kittson wrote that the treaty had been made "after the usual squabbling and manouvering," that it had been impossible, of course, to satisfy everybody, the half-breed settlement causing the most trouble, but that all unpleasant feelings would soon be forgotten and that the results of the treaty would be very beneficial. This treaty was later rejected by the United States Senate.

Great opposition was shown in the Senate to the ratification of the two Sioux treaties ${ }^{39}$ and great dissatisfaction was in evidence among the Indians themselves over the payment of their "just debts." This dissatisfaction led to considerable trouble at the time of payment to the upper Sioux, most of which was stirred up by Madison Sweetser who seems to have been the tool of other men who did not share in the spoils and who hoped to profit by blackmailing the traders whose claims were allowed. ${ }^{40}$ When the time came for payment under the treaties the chiefs demanded that the amount for the settlement of their "present engagements" be paid to them and be disposed of in open council. Ramsey, who had been appointed disbursing agent, held them to the terms of the traders' paper, however,

\footnotetext{
${ }^{28}$ Kittson to Fred Sibley, July 25, 1851, in Sibley Papers.
}

tion. It came from southern ation of fraud and deceit which formed the ground of this opposion which to build Southern Senators not willing to extend the area of settlement to the north, 40 "My brother writes free State." Folwell, Minnessota, 98.

combine, is dhether writes me that Sweetser, under the effective tuition of the Ewings \& Rice void, and to induce the can to persuade the Indians to declare their obligations to us null \& our just dues. these noted individuls another phase in the history of the gigantic schemes of fraud in which these noted individuals are concerned." Sibley to Ramsey, Dec. 26, 1851, in Ramsey Papers. 
and settlement was made accordingly. For this action Ramsey was severely criticised in Minnesota by persons not financially benefitted by the arrangement.

As early as January, I 852 , Ramsey asked Sibley to bring about an investigation of his conduct in connection with the treaties, ${ }^{41}$ but the investigation did not materialize until ${ }_{1} 853$. A Senate committee was then appointed and it examined a few witnesses, but reported to the Senate that no conclusion had been reached. The Senate then authorized the President to appoint a committee to go to Minnesota and examine witnesses. President Pierce appointed Judge R. M. Young, of Illinois, and W. A. Gorman, the new Democratic Governor of Minnesota Territory, to make the investigation. Judge Young examined witnesses at St. Paul during the late summer of 1853 and made a lengthy report which was finally sent to the Senate. This report contained several criticisms of Ramsey's part in the disbursement of the money, but the Senate finally decided that the charges against him had not been sustained, and that the Senate considered his action highly meritorious and proper. ${ }^{42}$

The investigation seemed to implicate Sibley in the questionable conduct charged in connection with the treaties. An article which appeared in the Washington Evening Star caused Sibley to write to Governor Gorman asking if there was anything in the report made by him and Judge Young which was sufficient ground for such implication. To this inquiry Governor Gorman made the following reply: "I received your note of today calling my attention to an article in the "Evening Star," of Washington, which says that the report of Judge

\footnotetext{
41 "In the complication of politics here, the strong personal animosity that pervades society-I look for such insinuations (speculations $\& \mathrm{cc}$ ). I should be rather simple did I expect to fare better than others have done before me in administering the affairs of a frontier country. All $I$ can do is to preserve my hands unspotted-and I will esteem it a favor should the thing be breathed again, if you would say to these at Washington that I would esteem it a favor, whenever the charge comes from a responsible source, for them to institute an investigation. These things might be mortifying but a moments consideration teaches me that if I will live in the midst of this kind of population it is folly to complain of any consequences." Ramsey to Sibley, Jan. 14 , $1851,(52)$.

"Senate Journal, 33 Cong. 1 Sess. 211.
} 
Young upon the charges preferred against Ex. Gov. Ramsey seriously implicates you and you desire me to say as one of the Commissioners who investigated said charges whether it is true that our Report 'Seriously implicates' you. In reply I have to say that I am not aware of any thing in that report which implicates you or was intended to 'Seriously implicate' you. Nor was there anything proven on the investigation that would justify us in making such report." 43

The chief significance of this whole affair is that it illustrates the defect in the government's policy of regarding the Indian tribes as "nations" with which it would make treaties, since the methods employed in connection with these treaties were not unlike those used in other instances. If the method does not seem to reflect credit upon the men involved, it should be remembered that standards of honesty and morality change with time and that it is not always fair to judge men of one generation by standards of later times when the public conscience has become somewhat more keen on the conduct of public officials. It was inevitable that the Indians should be forced to give up the title to the lands in Minnesota, as elsewhere, and, as has been shown, no treaty could be negotiated unless the traders and half-breeds were favorable to it. "Such aid could be had only by paying for it. The device of allowing Indians to stipulate in treaties for the payment to traders of debts due them from individual Indians, as if they were tribal obligations, had long been practiced. But for the machinations of disgruntled parties desirous of being taken into the happy circle of beneficiaries, the scheme might have worked as quietly and comfortable as usual. An old interpreter says of these treaties that 'they were as fair as any Indian treaties." "' 44 That the public of that day approved the action of the men who made the treaties is shown by the future public careers of both Ramsey and Sibley. ${ }^{45}$ This whole matter was significant also

"Gorman to Sibley, Feb. 15, 1854 .

"Folwell, Minnesora, 101-102,

elected to the United Stater elected Governor of the State of Minnesota, and Ramsey was 
because it added one more cause of bitterness between the races and contributed to the Sioux outbreak in 1862 .

Irrespective of the means by which it was accomplished, there is no question that the negotiation of these treaties was one of the most important events in the early history of Minnesota because it resulted in the opening up of new areas of settlement. The population of the territory grew by leaps and bounds after this event, and Minnesota was ready for admission into the Union in the short space of seven years. ${ }^{46}$

"Much assistance in the parts of this chapter dealing with the Sioux treaties was received from an unusually good Master's Thesis in the library of the University of Minnesota by Miss Ruth Thompson, "The Sioux Treaties at Traverse des Sioux and Mendota in 1851 and their Outcome." 


\section{CHAPTER VIII}

\section{TERRITORIAL GROWTH AND THE ORGANIZATION} OF A STATE

Several considerations induced Sibley not to be a candidate for re-election for another term in Congress. He believed that his services were not fully appreciated by a large number of people at home where the usual frontier feeling existed that one man was about as well qualified as another for political office. Also he had no desire to go through the bitterness of another campaign like that of 1850 . The differences between himself and Rice had not yet been healed when he decided to retire and it was necessary to show some spirit of conciliation if the Democratic party in Minnesota was to become united. Business considerations also probably had some influence on his decision. The prospects of becoming Governor of Minnesota Territory also was a factor in causing him to decline another nomination as delegate. His name had been mentioned in connection with the governorship as early as 1847 , even before the territory was organized. ${ }^{1}$ If Lewis Cass had been elected President in 1848 instead of Taylor it is possible, if not probable, that Sibley would have been strongly considered for the governorship. Although he had at that time not yet announced his politics, still he was a personal friend of Cass and was, beyond question, the most prominent man in the region which became Minnesota. As the year $185^{2}$ approached, the Democrats were hopeful of a national victory and this would mean a change of officials in Minnesota Territory. When Pierce was elected, Sibley's friends urged his appointment to the governorship ${ }^{2}$ and, for a time, they were

\footnotetext{
1"Why will you not take the Governorship? You can get it for the asking." D. G. Fenton
to Sibley, April 13,1847 .

${ }^{2}$ There is a recommendation of Sibley, signed by 58 members names of Henry Dodge, J. C. Breckenridge, and Andrew Johnson, in the Sibley Papers (Misc.).
} 
quite confident of success. During 1852 friends of Sibley and Rice brought about an agreement between them to effect a reconciliation between the Democratic factions in Minnesota and this removed opposition from that quarter to Sibley's appointment as Governor. ${ }^{3}$ The two chief reasons why Sibley was not appointed seem to have been the attitude of Stephen A. Douglas and the fact that Sibley was connected with the fur trade. Douglas used his influence against Sibley because the latter was known to favor the nomination of Cass in 1852 rather than Douglas. Sibley's connection with the Sioux Treaties of $185 \mathrm{I}$ was used against him but Pierce stated that it did not influence his decision. ${ }^{4}$ The outcome of the matter was that Willis A. Gorman, of Indiana, was appointed governor and served during the Pierce administration. Sibley closed out his connection with the fur trade about this time and turned his attention to other business. Except for one term in the territorial legislature, $1854-55$, he gave the next four years to business, but he was ready at all times to assist in any way the development of the territory and its advancement towards statehood. Since Sibley next emerges from private life as Governor of the State of Minnesota, it is necessary to sketch the chief features of territorial growth.

During the period that Sibley was in private life the territory grew by leaps and bounds. The census of 1850 gave Minnesota a population of 6,077 , of which 1,586 were born in Minnesota, 2,511 born in the United States outside of Minnesota, and 1,977 were foreign born. The New England element was particularly strong, although it was mainly a generation or more away from New England proper, as was the case with Sibley. ${ }^{5}$ New York furnished more settlers to Minnesota than any other single State, followed in order by Maine, Wisconsin,

${ }^{2}$ Rice to Sibley, Feb. 3,1853 . This was the first letter that had passed between them since 18. Hostility broke out between the two men, however, a few years later.

4. C. Dodge to Sibley, April 1, 1853. Also Eastman to Sibley, Dec. 9, 1853.

b Of the twenty-seven members of the first territorial legislature, eight had been born in New England, four in New York, six in Canada, two in Missouri, and one in each of the following: Delaware, Ohio, Michigan, Pennsylvania, and Virginia. The nativity of two is unknown. 
Ohio, Pennsylvania, Illinois, New Jersey, and Vermont. Most of the population was along the Mississippi and St. Croix rivers and in the Pembina region of the Red River valley. Ramsey county had a population of 2,222; Pembina county had $\mathrm{I}, \mathrm{I}_{34}$; and Washington county had $\mathrm{I}, 056$. More than twothirds of the people of the territory lived in these three counties. Dakota county came next with a population of 584 , followed by Benton county with 418 , Wabashaw with 343 , Wahnahta with I60, Mahkahta with 158 , and Itasca with $97 .^{6}$

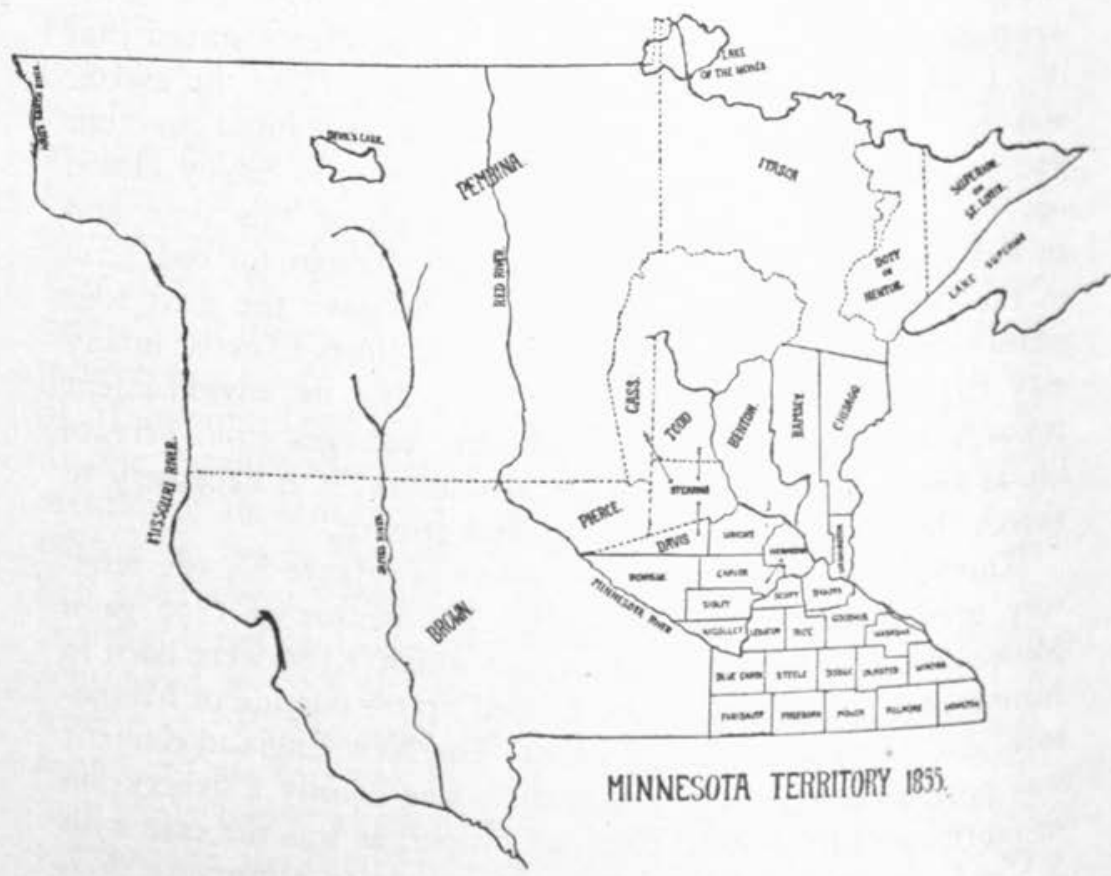

The settlement of Minnesota Territory progressed with remarkable rapidity down to the time of the Panic of 1857 . One way of observing the increase of settlement of a territory is to see where new counties were established in the different years during the period. Unorganized counties were created

'See the map for the location of these counties. 
in those parts of the territory where the population was not sufficient to justify regular county government. These counties were usually very large in area and as the population increased new county lines were run and the smaller areas given regular county government. By reference to the map of Minnesota Territory in 1849 it will be observed that there were only three organized counties at that time and that these were in the region between the St. Croix and the Mississippi rivers. Most of the people of this region were connected either directly or indirectly with the "lumber trade" which was the principal industry in Minnesota during the territorial period. These men were, as a rule, tresspassers on the public lands and large amounts of timber were cut annually and floated down the rivers. $^{7}$ No surveys of the public lands were made before 1853 west of the Mississippi, but this fact did not prevent the settlers from crossing the river and taking up the fertile lands in the region ceded by the Sioux in 1851 . The existence of organized counties in this region in advance of the surveys is evidence that squatters were taking up the agricultural lands west of the Mississippi and in the Minnesota river valley. ${ }^{8}$ In $185^{2}$ Hennepin county was organized west of the Mississippi at the Falls of St. Anthony, including the lands embraced in the city of Minneapolis. Pembina county was also declared to be fully organized in 1852 . The legislature of 1853 organized several new counties out of what had been Dakota and Wabashaw counties. By 1854 the surveys had been made in the southeastern part of the territory so that county boundaries begin to follow the survey lines; before that time they had been described by natural features only. Counties were organized

\footnotetext{
${ }^{7}$ Report of the Surveyor General to the Commissioner of the General Land Office, in Executioe Documents, 23 Cong. 1 Sess. $1: 70-72$.

3 "From the report of the surveyor general of Wisconsin and Iowa whose district includes also the Territory of Minnesota, it will be perceived that the emigration to that region is so great that it is impossible for the surveys to keep pace with the settlements." Report of Commissioner of the General Land Office, 1854 , p. 10.

" "At the time that this county was organized $(1852)$ it contained only thirty voters; at the election last October $(1854)$ there were more than 400 votes polled. . . The population of the county is now (1855) estimated at from 4,000 to 5,000." Mimnesola Year Boak, 1855, p. 27.
} 
each year and by 1857 most of the land in the Minnesota river valley and south to the Iowa line was pretty well settled.10 Land sales increased each year up to 1855 and then decreased until the Panic of 1857 when they became very small. During the decade, 1850-1860, some I,812,196 acres of land were sold in Minnesota at an average price of \$1.27 per acre.

The first wheat shipped from Minnesota was in 1857 and some flour may have been sent out as early as $185^{8.11}$ The city at the Falls of St. Anthony was, of course, destined to be the great "flour city" of the world, but this development did not come for many years after the decade under consideration. It was lumber mills, rather than flour mills, that caused the early growth of Minneapolis. Minnesota made the transition to agriculture during this decade ${ }^{12}$ and wheat and flour increased in importance as the years went by.

In the spring of 1857 the people of Minnesota were expecting the usual movement of population from the East. It was reported in the territory that industrial unrest in the East would cause a large number of people to come to the Mississippi valley during that year ${ }^{13}$ but when the Panic of 1857 occurred, immigration dropped off materially and there was a shifting of the population already in the region from the towns to the country, or, in other words, from industrial pursuits to agriculture. ${ }^{14}$

By 1860 Minnesota had a population of 172,023 , of which I1 3,295 were born in the United States, of which number 34,305 were born in Minnesota. Of the other States contrib-

${ }^{10}$ Minnesota Year Book, 1853 , p. 29. Also Report of Surveyor General, 1855 , in Messoges and Documents, 1855-56, Part I, p. 198 .

${ }^{11}$ Rogers, "History of Flour Manufacture in Minnesota," in Minnesota Historical Collections, 9:38. Also Hill, "History of Agriculture in Minnesota," in Minnesofa Historical Col-
lections, 8:276-77.

${ }^{12}$ Robinson, Economic History of Agriculture in Minnesora, p. 45

12 Pioneer and Democrat, May 23,1857 .

4 "St. Paul, the capital May 23,1857 . panic. This population was ind largest city, is said to have lost half its population during the quence, the cultivated area in the main transferred to agricultural pursuits and, as a consequadrupled, while the population of than doubled in $185^{8}$ and in several counties more thith an increase of about 50,000 in the previous year." Saby, "Railroad Legislation in Minnesota," 
uting to the settlement of the State, New York still led with a total of 21,574, followed by Pennsylvania, Ohio, Wisconsin, Maine, Illinois, Massachusetts, Indiana, New Hampshire, Michigan, Connecticut, and Iowa. Among the foreign born population, the Germans came first with 18,400 , followed by the Irish, Norwegians, British-Americans, English, and Swedes. These foreigners settled especially in Ramsey, Fillmore, Hennepin, Goodhue, Dakota, Carver, Houston, Winona, Washington, Rice, and LeSueur counties. Most of the Germans settled in the Minnesota river valley and the German element predominates today in many communities in that section.

It has previously been shown that Minnesota Territory was normally Democratic and that, except for factional fights, that party could have had control from 1849 down to the very close of the territorial period. It was expected that Minnesota would be a Democratic State and the leaders of that party were anxiously looking forward to the period of statehood with the increased number of offices to be filled. This pleasant political dream of permanent control by the Democrats was shattered by the passage of the Kansas-Nebraska Bill and the organization of the Republican party. The people of Minnesota, as elsewhere in the North, irrespective of previous party affiliations, divided on the question of slavery extension and the opponents of the policy embodied in the Kansas-Nebraska Bill formed themselves into the Republican party. This movement took shape in Minnesota during 1855 , and in the following year the new party gained control of the territorial legislature. There was a preliminary Republican convention held at St. Anthony on March 29, 1856, and a convention was called for July 25 to organize the party and to nominate a candidate for delegate to Congress. ${ }^{15}$ It was suggested in the call that

Is Minnesota Territory was represented in the Philadelphia convention that nominated Fremont in $18 \mathrm{~s} 6$. Dr. J. B. Phillips, of St. Paul, was on the committee on credentials, Ramsey was on the platform committec, and M. S. Wilkinson was chosen a member of the National Republican Committee. Fremont seemingly was not the first choice of the Republicans of Minnesota, although they, of course, would have no voice in the election. Daily Minmesotian, June $27,18 \mathrm{~g} 6$. 
the delegates to this convention be elected on July 4 , "there being no better mode of celebrating that sacred day than by raising once more to the breeze the banner of Freedom so long obscured by the dark clouds of human bondage." Two issued were put forward in this call and all citizens regardless of previous politics were urged to come into the new party. On the slavery question the circular stated: "That the tendency of our Government in late years and at the present time is antirepublican and in a directly opposite direction from that intended by the enlightened founders, and demanded by the inalienable rights of man, is too surely attested by the recent outrages of popular sovereignty in Kansas, and the unlimited extension of Human Slavery sought by the repeal of the Missouri restriction." The other issue was the liquor question and on this subject the circular contained the following statement: "That our fair Territory needs to be redeemed from the withering blight of unrestricted traffic in intoxicating liquors is too well proven by our statistics of pauperism and crime having their almost only sources in this nefarious traffic."

William R. Marshall, one of the principal leaders in the organization of the new party, was nominated to oppose Rice for delegate in Congress and it is generally believed that, except for the temperance plank in the platform, he would have been elected. The fact that he came so near to election in the first campaign after the organization of the Republican party and the further fact that the Republicans gained control of the territorial legislature thoroughly alarmed the Democrats. It was evident that the next test of strength between the parties would be a hard fought campaign. This test of strength came in connection with the formation of a State constitution and the transition to statehood.

By 1856 the people of Minnesota had begun to feel that they were ready for statehood. Governor Gorman recommended that the legislature take steps for the formation of a State constitution and such a bill was passed by the territorial legislature even before the passage of the enabling act by 
Congress, but the bill seems to have been lost by the Committee on Enrollment and was not presented to the Governor for his approval. The purpose of this move was probably to help force the matter on the attention of Congress rather than to actually attempt State organization.

On December 24, 1856, Rice introduced into Congress a bill for the organization of Minnesota as a State and on January 31,1857 , Grow, of Pennsylvania, reported as a substitute the bill which became the enabling act. This bill was in the usual form and gave Minnesota her present boundaries. It also provided for a constitutional convention, the delegates to which should be chosen on the first Monday in June, 1857. The convention was to meet on the second Monday in July and proceed to the making of a State constitution, if the delegates so assembled were in favor of statehood. The bill passed the House by a vote of 97 to 75 and, after considerable debate, passed the Senate by a vote of 31 to $22 .{ }^{16}$

In the choice of delegates to the convention there were some seats contested and the composition of the convention would depend on the action of the committee on credentials. For this reason both Republicans and Democrats were exceedingly anxious to control the organization of the convention. Since the hour of the meeting was not specified, the Republicans assembled in the hall on Sunday night, July 12, and were in possession, waiting for the appearance of the Democratic delegates. At 12 o'clock noon on July 13 the Democrats appeared and the meeting was called to order by C. L. Chase, Secretary and acting Governor of the Territory. The Democrats promptly voted that the convention adjourn until 12 oclock noon of the following day and withdrew. The Republicans refused to recognize this adjournment and proceeded to organize themselves into a constitutional convention. On the following day at the appointed time the Democrats re-appeared but, finding the hall "in possession of a meeting of the citizens

${ }^{10}$ Congressional Globe, ${ }_{34}$ Cong. 3 Sess., 201, 517, 519, 542, 734, 808, 814, $860,877$. 
of the Territory" who would not vacate the room at the demand of the Secretary of the Territory, adjourned to the council chamber in the opposite wing of the building and elected temporary officers of the convention. Sibley was elected president pro tem of the Democratic convention, which adjourned from day to day until July 27 , possibly waiting partly for Democrats to arrive to contest seats in the convention, but on that day they resolved that they constituted the regular convention and Sibley was elected president. ${ }^{17}$ The result was that two conventions were held, ${ }^{18}$ but, since good models for State constitutions existed, the two conventions, drawing largely from the same sources, came to about the same results in the formation of a constitution for Minnesota. The chief matters of importance debated were the questions of boundaries and the suffrage. On the latter point the subject was in regard to negroes and aliens voting and some delegates even advocated that Indians should be given the ballot when they should declare their intentions of becoming citizens. Even the Republicans voted against extending the suffrage to negroes. ${ }^{19}$

The Democrats had the advantage because of the fact that the territorial officers refused to allow pay to the members of the Republican convention, who then adopted a more conciliatory attitude. It was also feared by both parties that the irregularity of a double convention might prejudice Congress against the admission of Minnesota. Finally, on August 8, Judge Sherburne offered a resolution in the Democratic convention proposing a Conference Committee to meet with the Republicans and endeavor to heal the schism. This resolution was indefinitely postponed. On August II, the Republican convention passed the identical resolution which Judge Sherburne

17 Tournal of the Constitutional Convention of the Territory of Minnesota, 1, 2, 17, 21. ${ }^{18}$ The debates in both conventions were published and are in the library of the Minnesota
Historical Socity.

crat, Sept. 10, 1857 . The clipping from the Chicago Times was published in the Pioneer and Demoword 'white', 1857 : 'The vote in the Republican convention in Minnesota on striking out the word 'white' in the clause conferring political rights on 'citizens' was, yea 17, nays 34. The convention unanimously resolved that negroes were born free and equal to the white man, but refused by a vote of two to one to admit the negro to the enjoyment of the equality to which
they said he was born." 
had proposed and appointed a Conference Committee of five to confer with a similar committee which they hoped the Democrats would appoint. Saner councils prevailed in both conventions and the joint committees agreed upon a constitution. ${ }^{20}$ The Republicans, who were younger and less experienced men, seem to have bowed to the inevitable as gracefully as possible, although their work was actually further along and nearer completion than that of the Democrats. Sibley, in a farewell speech to the Democratic convention, claimed that the document agreed upon was essentially the work of the convention over which he had presided. ${ }^{21}$ Neither convention had yet drawn up a completed constitution, however, when the conference committee was agreed upon, the conclusions of each on the various questions involved being only in the committee report stage.

The constitution was referred to the people in an election on October 13,1857 , and was ratified by a vote of 35,140 to 700.22 At the same time the people of the Territory voted for State officers. The Republicans nominated Ramsey for Governor and the Democrats nominated Sibley. ${ }^{23}$ In a speech before the nominating convention, September 16, 1857, Sibley expressed his views of the Republican party and the slavery question and pointed out the importance of the coming election. "Who are our opponents?", he asked. "The Republican party, so styled by themselves, comprise the Know Nothings, the Free Soilers, the Abolitionists, the Maine Law Advocates, in fact every wild and crude fanaticism of the day has there found a resting place, and the assemblage of discordant elements has no cohesive power except its common hatred for the Democracy,

20 Fournal of the Constitutional Consention of the Territory of Minnesota, 75, 83, 159 .

It "It was atopted by ou politicat opponents as it first emanated from this body, with few and

.

"Debates and Proceedings of the Minnesola Constriturional Comandidate for the first Govern-

va "There is a propriety in the nomination of Mr. Sibley as a candidate for the first Govern- It norahip of the State of Minnesota, which must meet with general and cordial approbation. ient is fit that the man whose efforts secured its existence as a Territory should become and Democral of the first and highest honors within the gift of our new-born State."

Sept. 18,1857 . 
and its common desire for the spoils of office. We have been charged by them with being a pro-slavery party, an accusation which every man within the sound of my voice knows to be false. We deny the right of Congress any jurisdiction over this question and we deny its power to say to this or that State or Territory 'You shall, or you shall not, have this or that domestic institution in your midst.' We are all opposed to slavery extension so far as that object can be attained within the limits of the Constitution; but we hold it is the right of each State and Territory to settle these matters for themselves without interference from any quarter. This is one of the cardinal principles of the Democratic party." "Gentlemen, we have a contest before us," he said in closing, "which, politically speaking, is of more importance than will again take place for years. It would be a burning shame if we allowed Minnesota to enter the Union under Republican banners, thereby repudiating the great Democratic party which has strengthened and supported us during our Territorial dependence."

The campaign was hard fought and frauds seem to have been committed by both parties, one being about as guilty as the other. The result of the election was in doubt for several days until returns could come from the Pembina region and other distant settlements. Finally it was announced that Sibley had won by a majority of 240 votes out of a total vote of 35,340 . The Republicans did not concede Sibley's election and through"out his administration continually referred to him as the "Governor by fraud." ${ }_{25}$ The Pioneer and Democrat announced Sibley's election in large headlines and affirmed that the KansasNebraska Bill, the Dred Scott Decision, President Buchanan, and Stephen A. Douglas had all been "endorsed" by the people of Minnesota. ${ }^{26}$

is Pioneer and Democrat, Sept. 16, 1857 .

Tribune (Democratic): "The Minnesotian, I, 1858, published the following clipping from the Dubuque whether he will accept it or not. His of election will be given to Mr. Sibley, but doubt exists majority of the votes cast in the territory. Some districts gave Sibley 100 majority where it
has been proven that not a dozen

* Pioneer and Democrat, Nov. 3,1857 . 
The bill to admit Minnesota into the Union was, after a long and spirited debate, passed by the Senate on April 7, 1858, and by the House on May II, $1858 .{ }^{27}$ The news reached Minnesota on May ${ }_{13}$, having been telegraphed to LaCrosse and sent from there up the river. ${ }^{28}$ The State officers took their oaths of office on May 24, 1858, and Minnesota entered upon her career as a State within the American Union. ${ }^{29}$

${ }^{n}$ It was claimed that the admission of Minnesota was delayed by the Buchanan administration in order to force Kansas into the Union under the Lecompton Constitution at the same time that Minnesota was admitted as a free State. Minnesotian, Jan. 21, 1858, printing a clipping from the Chicago Tribune of Jan. 16, 1858.

2 Pioneer and Democrat, May 14,1858 .

2 The State administration, including the United States Senators, was Democratic. The Dubuque Tribune printed the following regarding the party: "It appears that the Democratic party of Minnesota is composed of two classes, Indians and Irishmen. In the election of the two United States Senators from that State, the other day, the greatest care was taken to do equal and exact justice to both wings of the party. Accordingly, Mr. Rice was chosen as Senator for the Indian division, or the breech clout Democracy, and Mr. Shields as the Senator for the Irish portion of the unterrified. This impartial and even-handed justice is very touching." Quoted in the Minnesotian, Jan. 1, $185^{8}$. 


\section{CHAPTER IX}

\section{THE ADVENT OF THE RAILROAD TO MINNESOTA}

The period of Sibley's governorship was not a time of great prosperity, and the administration was not regarded as an unqualified success. Several perplexing and embarrassing situations presented themselves which would have prevented a brillant administration no matter who was governor. The transition from territorial to state government was no sooner accomplished than the whole country found itself in the midst of the Panic of I857 which fell with great severity on the new State. This situation continued during most of Sibley's administration and prevented much real constructive work of great moment. Several important laws were placed upon the statute books, the most important of which dealt with such matters as education, the organization of the militia, and the regulalation of banking; but by far the most important question of the time was that of railroads for Minnesota, involving the famous "Five Million Dollar Loan" of State credit. ${ }^{1}$ It is necessary to sketch briefly the history of the previous efforts to secure railroads in order to present this troublesome question in its proper light.

For many years the people of Minnesota had tried to get railroad connections with the lines extending from Chicago to the Mississippi river in order to have a transportation system open the whole year through. As early as $185 \mathrm{I}$, while Sibley was in Congress, the Territory had asked for land grants for railroads. ${ }^{2}$ No results were accomplished at that time and in I853 Governor Ramsey recommended that the territorial

\footnotetext{
${ }^{1}$ The two best accounts of the "Five Million Loan" are, Folwell, "The Five Million Loan," in Minnesota Historical Collections, $15: 189-214$, and Saby, "Railroad Legislation in Minnesota," in Minnesota Historical Collections, $15: 35-48$.

${ }^{2}$ See Chapter VI above.
} 
legislature send another memorial to Congress on the subject. This was not done at the time, but the legislature did incorporate five railroad companies which were never organized. In I854 the legislature again memorialized Congress for a land grant; at the same time it incorporated the Minnesota and Northwestern Railway Company and transferred to it any lands which the State might receive from the United States for railroad purposes. Most of the politicians of Minnesota were interested in some way in this company. Congress acted favorably upon the memorial, but the act making the grant was drawn in such a way as to exclude the above named corporation from the land grant. The wording of the bill was then changed by the erasure of the word "and" and substituting the word "or" after it had left the House and before it reached the Senate. This change was made in order to enable the Minnesota and Northwestern Railway Company to receive the grant. When the piece of trickery was discovered, the whole act was repealed by Congress, and Minnesota was left without the immediate prospects of railroads. The railway company maintained that the repeal of the land grant was invalid, and that the act making the grant gave them title which could not be taken away. The territorial courts decided the question in favor of the railroad company, but the United States Supreme Court upheld the validity of the repeal. ${ }^{3}$

Altogether, fifteen companies were chartered by the legislature during the territorial period, and not a single mile of railroad was constructed. Four of these companies were organized, and Congress was again appealed to for a land grant which was made shortly before the admission of the State. The act of Congress specified the routes, and the State was only to act as agent for the transfer of title to the companies. The grants were similar to the Illinois Central grant of 1850 in form. One route was as follows: "From Stillwater, by way of St. Paul and St. Anthony, to a point below the foot of Big Stone

\footnotetext{
${ }^{2}$ Folwell, Minnesove, 124.
} 
Lake and the mouth of the Sioux Wood river (the present town of Breckenridge), with a branch via St. Cloud and Crow Wing, to the navigable waters of the Red River of the North, at such point as the legislature of the said territory may determine." The Minnesota and Pacific Railroad Company was organized on May 22, I857, and the lands in this grant were conveyed to it. Another route extended "From St. Paul and St. Anthony, via Minneapolis, to a convenient point of junction west of the Mississippi, to the southern boundary of the Territory in the direction of the Big Sioux river, with a branch via Faribault to the north line of the State of Iowa, west of range sixteen." This road became the Minneapolis and Cedar Valley Railroad Company, of which Sibley was one of the directors. Still another route went "From Winona, via St. Peter, to a point on the Big Sioux river, south of the forty-fifth parallel of north latitude." This became the Transit Railroad Company. The other route extended "From La Cresent, via Target Lake, up the valley of the Root river to a point of junction with the last mentioned road (the Transit) east of range seventeen." This became the Southern Minnesota Railroad Company.

The outlook for railroads in Minnesota was regarded as very favorable when the Panic of 1857 came and changed the optimism into deepest gloom. Since the land was to be granted only as sections of the roads were constructed, the railroad companies represented that if they could only get the money to construct the first twenty miles of the road bed, they could then receive the land for that part of the road and use it as a basis of credit for funds to continue construction. A provision in the State constitution, recently ratified, prohibited the loaning of the State credit to individuals or corporations. So great was the desire for railroads, however, and so sure were the people that the roads would be constructed if some financial assistance was extended to them that the provision was replaced

\footnotetext{
4Folwell, Minnesota, 161. Also Saby, "Railroad Legislation in Minnesota," in Minnesols Historical Collections, 15:7-8.
} 
by a constitutional amendment which authorized a "loan of public credit" to the railroad companies. ${ }^{5}$

This "Five Million Dollar Loan" was a prominent subject in Minnesota politics for more than twenty years. The people of the State claimed that there was a distinction between a State debt for internal improvements and a loan of public credit, and insisted that it was never their intention that the railroad bonds should be paid by the State. A study of the contemporary newspapers leads to the conclusion that this contention was not well founded because the full consequences of their act was held up before them at the time that the amendment was up for ratification. The press of the State divided on the question at the time and the subject was thoroughly discussed pro and con, and if the people did not understand what they were going into it was simply because their enthusiasm for railroads blinded their vision as to the possibility of disaster to railroad companies with no better financial backing than the ones they propsed to deal with. The Pioneer and Democrat opposed the loan at first, ${ }^{6}$ but later come out in favor of it. The Minnesotian consistently opposed the loan all the way through and insisted that the railroad companies were not formed honestly to construct a transportation system for the people of Minnesota, but were speculative in character, the aim being to make money out of the construction work and from speculation in lands and town sites. It also told the people over and over again that the security for the State bonds was not adequate, and that the bonds would eventually fall back upon the State treasury for payment. ${ }^{7}$ The companies seem to have carried on an extensive propaganda; meetings were held in different parts of the State, and the Minnesotian insisted that they were gotten up by "interested parties."s

'This amendment was adopted April 15,1858 , and the State was not admitted until the following month.

- Pioneer and Democrat, Feb. 9, $1855^{8}$; Mar. 11, Mar, 14, and April 15, 1858. In the first issue mentioned the editor was not convinced, but in later ones he was.

${ }^{7}$ Daily Minnesotian, Feb. 25, 1858, and almost every issue until April $15,185^{8}$.

'Ibid, Feb. 26, 1858. 
Printed matter was furnished by the companies to be scattered broadcast over the State, and the charge was openly made that bribery had been used to get the amendment through the extra session of the legislature in the spring of $185^{8.9}$ The Mankato Independent, March I9, I858, said: "We cannot but look upon the scheme as a Creat Fraud upon the people, perpetrated under the guise of facilitating operations upon the projected Railroads of Minnesota." In spite of all the argument against the proposition, the people of Minnesota were determined to risk all for the sake of railroads, and the amendment was adopted. The Minnesotian in considerable disgust at the outcome of the election printed the following editorial on April 16, the day following the election: "The populace, yesterday, in voting for the Loan of 5,000,000 of dollars to the Railroad Companies, went it with a mad and blind rush, only to be compared to that of a bull in a china shop . . . and all felt as good doubtless as Adam did when he ate the apple in Paradise." Sibley did not openly express his attitude on the question while it was before the people, ${ }^{10}$ but he stated several years later that he voted against the loan, notwithstanding the fact that he was one of the directors of the Minneapolis and Cedar Valley Company."

The chief arguments in favor of the loan were summarized in a report of a select committee of the State senate, January 30, I 858 , of which two thousand copies were printed and distributed over the State. ${ }^{12}$ This report stated that surveys for the roads had been made and "except for the panic of ' 57 the companies would have been able to construct thirty miles each, as would have afforded them a basis for the issue and sale of bonds for the rapid extension of the lines." Unaided, the companies

The Minnesotian, March I, 1858, quoted the Times as saying that $\$ 40,000$ in stock had been used to bribe the legislature. The Minnesotian, March s3, made the statement also in an article on "The Why and Because of the $\$ 5,000,000$, March 23,

${ }_{10}$ Pioneer and Democrat, April 18, 1858.

Loan," p. 49, in library of "United States Circuit Court in Equity," in volume on the "Five Million 12 This pamphlet together with in library of Minnesota Historical Society.

the title "Five Million Logether with the above and twenty two others are bound together under the Sibley Papers. 
would be unable to proceed with the construction of the roads for some time at least. "Hence an inevitable postponement of these important improvements, unless the aid of the State is extended for the purpose of placing our railroad interests above temporary depression which has resulted from the convulsion of 1857 ." The report also emphasized the advantages which would come from the spending of $\$ 5,000,000$ in Minnesota: (a) markets would be stimulated; (b) means of liquidating liabilities to other sections of the country would be placed in reach of business men; (c) wages of labor would not depreciate; (d) immigration to Minnesota would be stimulated; (e) "and above all, there would be an amount of railroad construction sufficient to furnish a basis satisfactory to capitalists for the loan directly to the Companies of whatever funds are requisite to push forward our entire system of internal improvements to speedy completion." "All this can be effected within one year, every preliminary can be arranged before the opening of navigation on the Mississippi river; and instead of stagnation and corresponding depression in every walk of business or enterprise, an opposite state of things pleasing to the patriotic citizen will certainly be induced, without sacrifice or injury to any interest, public or private."

By way of security to the State the companies were to deposit with the State Treasurer first mortgage bonds, of equal amount, which were to be sold in case of default in the payment of interest on the State Railroad Bonds; or, at the option of the Governor, instead of the sale of the first mortgage bonds, the mortgage on the roads and their grants of land could be foreclosed. Also the net profits of the roads were pledged for the payment of interest. These were the principal arguments which influenced the people to vote for the constitutional amendment permitting the loan of State credit. The people overlooked the elementary facts that the companies had nothing back of them, hence a mortgage was worthless; also that there were no immediate prospects of net profits with which to pay the interest. The Senate Committee cited precedents 
of similar action by Tennessee and Massachusetts, and concluded that Minnesota was justified in extending credit "and that, too, a nominal liability, with unquestionable security to the taxpayer, and a certainty of effecting the salutary results already referred to." The people evidently listened to this argument rather than to that of the Minnesotian and other papers which opposed the loan.

The aid was to be extended to the companies in the following manner. To each company the Governor was directed to issue $\$ 150,000$ of special State bonds, bearing $7 \%$ interest, payable semi-annually in New York, redeemable any time after ten years. The companies were expressedly forbidden to negotiate these bonds except at par, and the proceeds from their sale was to be used in the location, construction, or equipment of the roads. On the companies complying with these conditions, the Governor was to issue $\$ 50,000$ more of bonds under the same circumstances, but the total aid must not exceed $\$ 5, \infty 00,000$, nor more than $\$ 1,250,000$ to any one company. In case any company should default in the payment of interest, no more bonds were to be issued to it.

The amendment to the State constitution was adopted by an overwhelming vote on April 15, 1858, and the promoters of the railroads immediately went East to raise the necessary capital. Funds were not forthcoming, however, as soon or as easily as the enthusiastic Westerners expected. W. A. Jones, one of the promoters, wrote to Sibley on May 15, 1858, from New York, that Wall Street required "much, very much time in which to consider and reconsider and to turn over \& turn over again and again a business proposition than we western men do." He also wrote that the directors were trying to do an honest piece of work, and said that it would be much easier to arrange with "dummy" contractors "and leave the whole line when completed a rotten \& insolvent concern. But, Sir, can you believe it that this determination on our part to make clean $\&$ honest work of it, is in reality the greatest hindrance we have, to encounter? Strange, indeed, it is but true, Sir, as Heaven." 
In his inaugural address, June 4, 1858, Sibley clearly stated his attitude in regard to the issue of State bonds. "Before any State bonds can be issued to these companies, they must produce satisfactory evidence, verified by the affidavits of certain of their officers, that a specified amount of labor has been previously performed upon their respective roads. As the guardian of the interests of the State, during my term, it is proper for me to state that, while I should avoid being unreasonably strict with these railroad associations, I shall require to be satisfied by unquestionable evidence, that they have complied as well with the spirit as with the letter of the amendment authorizing the loan, and that they are conducting their operations, as parties to the contract with the people of the State, in good faith, before I will consent to deliver over to them any portion of her bonds." ${ }_{13}$

Construction work was begun on June 10, $185^{8}$, between St. Paul and St. Anthony where grading could be done with little difficulty, and the people of the State believed that their hopes for railroad transportation were soon to be realized. ${ }^{14}$ Matters were not going well in the East, however, in disposing of the State bonds. On August 2, I8 8 8, Isaac Atwater wrote to Sibley that the outlook was very discouraging, that the capitalists "have got the thing so bedeviled they do not know what they want, nor what is wrong about them now, but it seems as though a sort of impression was prevailing that something about them is wrong, which in these times is enough to frighten anybody." By the latter part of August, the situation was beginning to get desperate. On August 23, Atwater again wrote to Sibley and urged him to come East in September and try to place the bonds or raise money on the company's responsibility. Two days later the necessity of a default on the part of the companies was suggested. J. W. Taylor, in a latter to Sibley, said: "The more I think of the matter, Governor, the more fully I am satisfied that the only way to prevent default in

13 Pioneer and Democrat, June 4, 1858 .

${ }^{14}$ Minnesorian, June 11,1858 . 
the payment of interest is to allow the companies to use their first mortgage bonds to provide means for making these payments and to push construction to the point when the profits of the roads in operation will be adequate for the purpose. What I urge to enter on your executive Records will secure roads in operation - thus removing the only danger to which the system is exposed."

By the last of October, about thirty-five miles of grading had been done, but the necessity of raising money was more pressing than ever. "We must have bonds or money without delay," J. W. North wrote to Sibley on October 27, $185^{8}$. A controversy had arisen between Sibley and the directors of the companies, and this was what was holding up the issue of the bonds. The difficulty was over the construction of the expression "first mortgage bonds." Sibley insisted that the bonds turned over to the State Treasurer in return for the State Railroad Bonds should be prior lien bonds and not ordinary first mortgage bonds such as the companies might issue to other holders, as the companies were insisting upon. Sibley stood his ground until the Supreme Court of Minnesota issued peremptory mandamus upon him to issue $\$ 300,000$ of State bonds to the Minnesota and Pacific Railroad Company upon the officers of that company turning over to the State Treasurer an equivalent amount of the company's first mortgage bonds without prior lien in favor of the State. ${ }^{15}$ Sibley, as chief executive officer of Minnesota, was not bound legally to obey orders from a co-ordinate department of the government and his friends earnestly hoped that he would stand firm in his determination to preserve the State's credit. "The State of Minnesota has too much both for the present and the future at stake upon your decision to permit anything like retreat from the contest or quiet submission to the decision of any court (whether railroad judges or not)," W. G. LuDuc wrote to Sibley, Novem-

\footnotetext{
${ }^{15}$ Records, Executive Office, $1858-1862$, p. 63 , in archives in the Governor's office. This situation gave the Minnesotian an opportunity to take the "I told you so" attitude, which it did in an editorial Nov. 11,1858 .
} 
ber 20, 1858. "I was told while recently in St. Paul," he continued, "that you had determined to acquiesce in the decision of the court $\&$ issue the bonds. I hope it is not true. The court cannot compel you to issue the bonds." Ramsey Crooks, Sibley's old friend of fur trading days, wrote to him on November 22, 1858 , urging him to stand his ground. "The attempt of the Rail R. Companies of your State to coerce you into the exchange of their bonds for those of the State, before the iron is laid upon their tracks is looked upon here as nothing less than an attempt to defraud \& swindle the State and has already had the effect to throw suspicion upon her credit and place her in a false position. You have, Sir, a high duty to fulfill to yourself and country and let nothing deter you from doing so."

The directors of the companies were very bitter against Sibley for his attitude towards the issue of bonds. "Your Railroad decision has capped the climax," J. J. Noah wrote to him from Washington, November 24, 1858, "and these infernal railroad swindlers consider you the only obstacle between them and the plunder of the State. They will do everything in their power to get you out of the way. Governor Medary told me this last week when he was here." Sibley's friends felt at the time that he made a serious mistake in giving in to the mandamus. "It is reported here," H. Dollner wrote to Sibley from New York on December 2, 1858, "that you would probably have resisted the mandamus of the Supreme Court if you could have done it, and had you done it, you would have become a financial \& political hero of the Andrew Jackson stamp. I had for a few days a strong desire that you should have come here; but since I learn that you have been obliged to submit to your courts and as it is known that you are V. President of one of the R. R. Cos. I fear that your presence would not give that weight which it certainly would have given had you been here with Dr. Borup."'16

\footnotetext{
In 1871 while in the State legislature, Sibley made a speech explaining his reasons for giving in to the mandamus proceeding and expressing his regrets that he did not refuse to issue the bonds. See Chapter XI below.
} 
When Sibley decided to sign and issue the bonds, he determined to do the next best thing in his power and ruled that the companies could receive only one-half the amount for grading and the other half when sixty-two and one-half miles of each of the four roads should be completed and the cars running thereon. The records in the Governor's office contain the affidavits of the railroad officials and reports from special engineers sent out by the Governor to inspect the work before he issued any bonds for construction work.

In spite of the victory of the companies over Governor Sibley, capital was not forthcoming from the East. J. W. North again wrote to Sibley from New York, December 2, $185^{8}$, urging him to come East at once. "Almost all the papers of the city have attacked us," he wrote, "and nothing but a statement from the Governor can put matters right. The bare idea that there is a fight between the Companies and the Governor ruins the credit of the State. . . . I am now loaded with calls for money from our company and contractors; but I cannot raise a dollar till you get here and assure the people officially that the bonds are alright. And how it is that you can take the matter so coolly I cannot imagine." Only two days later North again wrote to Sibley, and this time he was in the depths of despair. "Your delay has spoiled everything. Our credit as a State and as a company is ruined. If you had come, as you agreed to, we might have breasted the storm. But now I fear it is too late. . . . You might have saved us if you would; but you have chosen to let Dr. Borup direct \& both our company and our contractors are ruined. You can draw what comfort you can from such reflection; I confess I can get none."

Sibley started East on December 8, 1858, to see what he could do in regard to negotiating the bonds, ${ }^{17}$ but he was entirely unsuccessful. ${ }^{18}$ By January, 1860, the bonds were selling

${ }^{17}$ Pioneer, Dec. 8, 1858 ; Minnesotian, Dec. 10, 1858.

is Sibley's testimony as reported in pamphlet "United States Circuit Court, Selah Chamberlain vs. Southern Minnesota and the St. Paut \& Sioux City RR. Co." P. 55, in volume on "Five Million Loan" in the library of the Minnesota Historical Society. Sibley ascribed his failure to the action of the Minnesotian. See also Chapter XI below. 
at twenty-five or thirty cents on the dollar. ${ }^{19}$ The people of the State were entirely disgusted with the way things turned out and when the Republicans gained control of the State administration in 1860 , partly no doubt as a result of this railroad episode during the Democratic administration, the legislature was hostile to the railroad companies. A committee of the legislature made an extended report of the situation on February 3, 1860, in which they said: "They (the companies) have not proceeded according to the spirit of the amendment to insure the construction of the Land Grant Railroads. So far as your Committee can discover, the Companies, since the passage of the Loan Amendment, have not furnished one dollar of capital to aid in carrying on their gigantic enterprise. They have sold and hypothecated large portions of their bonds at ruinous discount. They have paid extravagant salaries to incompetent or inefficient officers. With the exception of about fifty miles of well built superstructure, incomplete, fragmentary and disjointed portions of grading, costing on the average less than $\$ 3,000$ per mile, are all that these companies can show in return for the munificent issue of bonds made to them by the State. The State is immeasurably worse off today than if the Land Grant still remained in the State, and not a foot of ground broken. . . . The bonds issued to the companies have been, to a great extent, misapplied. . . . The credit of the State has been temporarily embarrassed, and the people have got no completed Railroads. . . . The three companies which have defaulted are without means or credit. Not a bond should have been issued to the companies unless they had the means and knew how they could complete the roads. It was not contemplated that they should construct a few miles of unfinished

Is Dousman to Sibley, Jan, 26, 1860. Dousman had bought some of the bonds at 50, and asked Sibley's advice about buying more. In his speech in 1871 Sibley said: "The failure to place the bonds in New York, except to a very limited extent, gave a finishing blow to their value in the market, although an effort was made to resuscitate them at home, where the presentaken by the State Auditor as securities for banking issues to a limited extent, upon the presentation of affidavits of responsible citizens that bone fide sales of the bonds had actual

for ninety-five cents on the dollar." Speech reported in Pioneer, Feb. 9, $187 \mathrm{r}$. 
road beds which the elements would soon obliterate. A poor return this for, first, the liberal grant of lands donated by Congress, and, second, of $\$ 5,000,000$ of bonds to be issued by the State. To expend the bonds without finishing the roads, at least in part, was a gross perversion of the object and purpose of the loan. . . . The greatest misfortune of the five million loan policy was the utter impracticability. In the first place, the loan was a great deal too large to be borne by the people of the State in its infancy, and at a time when a financial revulsion had paralysed the energy of the West. Again, the management fell into the hands of men without the business capacity or financial ability to accomplish their undertaking. . . The great question, therefore, is, not so much what have been the errors of the past, as what shall be the policy of the future. In fixing that policy, two important questions demand solution. How shall the State secure herself against further loss and how shall the State dispose of her obligations." ${ }_{20}$ The committee recommended that the State foreclose the mortgage on the road beds and pass an amendment to the Constitution for the settlement of the Railroad bonds.

When Ramsey succeeded Sibley as Governor on January I, I860, he recommended a settlement of the bond question, but the people were determined not to pay them. The validity of the constitutional amendment was attacked because it was ratified on April I 5, I858, and the State was not admitted until May II, I858. It was also claimed that the railroad companies were obligated to pay the principal and interest, and that the people of the State never intended that the amount should ever become a State obligation. The only action taken by the legislature was to propose two more amendments to the Constitution, both of which were promptly ratified. One provided that the amendment of 1858 should be expunged, and the other provided that no settlement of the Railroad Bond question should be valid until it had been approved by the electors of the State

${ }^{20}$ Pamphlet No. 6, pp. $\mathrm{t}-5$, in volume on "Five Million Loan," in library of the Minnesota Historical Society. 
by a referendum vote. In this form the question went through many years of Minnesota politics. Some $\$ 2,275$, 000 worth of bonds had been issued and still there were no railroads in Minnesota. Other attempts were made to reorganize the companies and secure the construction of the roads, but it was not until 1862 that the first line was put in operation, and that was only a short intrastate line. ${ }^{21}$

"For the final outcome of the Railroad Bond question and its probable effect upon Sibley's public career, see Chapter XI, below. 


\section{CHAPTER X}

\section{THE LAST STAND OF THE SIOUX JNDIANS IN MINNESOTA}

The most serious Indian massacre in American History took place in the valley of the Minnesota river in the summer of 1862 . The uprising of the Sioux in their last stand against the white men for possession of the soil of Minnesota differed from other conflicts on the frontier chiefly in the area involved and the number of victims slain. Similar causes had produced similar conflicts over and over again as the pressure of population pushed the Indians farther and farther towards the setting sun. King Philip, Pontiac, Tecumseh, Black Hawk, and Little Crow all tried in vain to stem the tide of white immigration. The story of the frontier is a story of the conflict of two races and civilizations which could have but one ending, the removal or extermination of the interior race.

The fundamental cause of the Sioux War, as of most of our Indian troubles, was the erroneous policy of the United States government in dealing with the Indian tribes. ${ }^{1}$ Deep dissatisfaction had been felt among the Sioux Indians of Minnesota since the negotiation of the treaties of 1851 , and the Indians had not become reconciled to the settlement of the traders' claims which had been forced upon them at that time. ${ }^{2}$ The delay in the enforcement of the treaties increased the resentment of the Indians, especially the delay in the payment of the annuities in 1862 . The Indians assembled in June of that year to receive the money and waited week after week while, as they said,

${ }^{1}$ See Chapter VII above.

${ }^{2}$ In September, 1862, when the Republican paper, The Minnesotian, was denouncing Sibley for the slow movement of his military forces, paper, The Minnesotian, was denouncing ing the chief blame for the Sioux War upon Ramsey for his part in connection with the traders' paper. Pioneer and Democrat, Sept. 10, 1862. 
their families were starving. The money did not arrive in Minnesota until August when the patience of the Indians had been exhausted and the outbreak was actually under way. In addition to these causes the existence of factions among the Sioux themselves no doubt helped to bring on the trouble. During the last years of Buchanan's administration Joseph R. Brown had been Indian Agent among the Sioux and had exerted great influence over them to the end that more of them than usual took up the ways of white men, or, in other words, became "farmer Indians." The "blanket Indians," those who retained their native customs, had a feeling of resentment against the former and against the whites for interferring with their wild life. ${ }^{3}$ With the election of Lincoln there was, as was usual in such changes of administration, a change in Indian officials. Great promises seem to have been made by these officials, which were not realized as the Indians expected, and this, together with the usual disregard of the rights of the Indians on the part of certain whites, added to the unstable situation on the frontier. Finally, the Indians knew that thousands of men had left the North for southern battlefields, and reports were current that the Northern arms were not faring well and that the Union would probably be dissolved. ${ }^{4}$ It has been stated, and was at that time believed by many of the people of Minnesota, that Southern agents were at work among the Sioux inciting them to insurrection, but no conclusive proof of this has been found. The Indians knew, however, that white men and half-breeds had left the region near the reservations to go South with the army, and it probably seemed to many of the Indians an opportune time for a decisive stand against the whites. Contemporaries were inclined to believe that plans had been made in advance by Little Crow, even involving an agreement with the Chippewas under Hole-in-the-Day, but the evidence does not substantiate such belief. ${ }^{5}$ It was realized by

${ }^{3}$ Chief Big Eagle, "A Sioux Story of the War," in Minnesota Historical Collections, 6:385.

-A further evidence of weakness in the whites in the minds of the Indians was the failure of the United States to capture and punish Inkpaduta for his raid in 1857.

'Several citations of authorities giving views that there was a prearranged plan are to be found in Minmesota History Bulletin, $1: 437$, note. 
the whites that there was a feeling of restlessness and dissatisfaction among the Indians which might lead to trouble, but seemingly the signs were but little more serious, if at all, just before the outbreak than they had been at any other time since $1851 .^{6}$

While all of these general causes were operating which might have brought trouble on the frontier at any time, the actual beginning of hostilities in 1862 appear to have been quite accidental and came as a complete surprise to the settlers. There are several versions as to the scene enacted at Acton in Meeker county on Sunday afternoon, August 17, 1862. According to Chief Big Eagle, in his story of the war, some young braves came upon a hen's nest and one of them took the eggs whereupon one of his companions remonstrated with him because the eggs belonged to a white man and it might cause trouble for the Indians. The latter was then accused of being a coward afraid of the whites, whereupon, in order to show his bravery, he said that he was not afraid to shoot a white man and dared the others to go with him, the affair resulting in the murder of the first whites. The murderers, according to this story, then fled to their tribe and reported what had happened. The Indians then held a council and decided to go upon the warpath, since blood had already been shed. ${ }^{7}$ According to another story, six Indians, said to be of Shakopee's band of Lower Sioux, appeared at the home of Robinson Jones and asked for food which was refused them. Their action being threatening, Jones took his family over to a neighbor named Baker where there was visiting that day a Mr. Webster and his family. The Indians followed and proposed a shooting match which was

- The general feeling of alarm had existed at least since 1857 when volunteer militia companies were organized. Flandrau to Huebschmann, April 16, 1857, in Commissioner of Indians Report, 1857, p. 72. Also Thomas Williamson to T. J. Galbraith, June 2, 1862, in Minnesota in the Civil and Indian $W$ ars, $2: 162-163$ Willo $T$. J. Galbraith, June 2, 1862, in usual be present at the payment of annu was not wholly unprotected. threatened trouble.

${ }^{7}$ Chief Big Eagle, "A Sioux Story of the War," in Minnesota Historical Collections, 6:389. 
agreed to by the whites. They all fired at the mark and began reloading. The Indians finished reloading first and immediately shot Jones. Mrs. Jones and Mrs. Baker were standing in the door and an Indian levelled a gun at Mrs. Baker whose husband sprang between them and received the bullet in his body. The Indians then shot Webster and Mrs. Jones. Mrs. Baker fainted when her husband was shot and fell backwards into the cellar, thus escaping being murdered. The Indians then went back to the Jones house and killed a young girl who had been left there and then returned to their tribe. ${ }^{8}$ Once begun, the Indians moved with great rapidity and fell upon the settlers before they knew of any trouble. On Monday August I8, there were massacres along the Minnesota river above New Ulm, and the latter place was attacked on the following day. On Wednesday Fort Ridgley was surprised, but, in spite of repeated attacks during three days, the place held out. On Saturday August 23 New Ulm was again attacked. The place was ably defended by Judge Flandrau, but on Monday August 25 it was abandoned and the people taken to Mankato.9

The news of the outbreak reached St. Paul on Tuesday August I9, and Governor Ramsey immediately went to Fort Snelling where orders were issued for four companies of soldiers to start for the scene of the disturbance. On the same day Governor Ramsey appointed Sibley as Colonel in charge of the expedition. ${ }^{10}$ In spite of the fact that there were not enough troops and that what few there were, were inadequately armed and provisioned, so great was the panic on the frontier that the soldiers were started immediately up the Minnesota river. On the following day Sibley wrote to Ramsey that the Austrian rifles with which the men were armed were "a very poor affair" and that the ammunition was too large for the rifles and had to

${ }^{8}$ Bryant and Merch, A History of the Great Sioux Massacre by the Sioux Indians, 84-85.

Minnesota Historical Collections, 9:439.

Ramsey to Stanton, Secretary of War, Aug. 19, 1862 , in Reconds, Executior Offee, $1858-62$, p. 590 , in archives of the Governor's office. Also Ramsey to Malmros, Adjutant General, in $M$ innesota in the Civil and Indien Wars, 2:165. Also Pioner and Democrat, Aug. 20, 1862. 
be sent back to Fort Snelling. "We shall need more guns, more ammunition, and more men," he wrote. ${ }^{11}$

The settlers in the Minnesota valley abandoned their homes and fled in terror towards the Mississippi. ${ }^{12}$ Destruction and desolation were evident everywhere, and Sibley, realizing the seriousness of the situation, called continually for more men to crush the uprising. "There is no use to disguise the fact," he wrote, "that unless we can now, and very effectually, crush this rising the State is ruined, and some of its fairest portions will revert for years into the possession of these miserable wretches who, among all devils in human shape, are among the most cruel and ferocious. To appreciate this, one must see, as I have, the mutilated bodies of their victims. My heart is steeled against them, and if I have the means, and can catch them, I will sweep them with the besom of death. Don't think there is exaggeration in the terrible pictures given by individuals. They fall short of the dreadful reality. This very moment the work of destruction is going on within ten miles, and yet $I$ have not mounted force enough to spare for chasing and destroying the rascals." ${ }_{13}$

About daybreak on September 3, 1862, the Indians attacked a detachment of troops at Birch Coolie, and a very sharp engagement took place. After a few hours the Indians were driven into the timber from which they kept up a continuous fire for some thirty-three hours. On the following day reenforcements for Sibley arrived and the Indians withdrew. ${ }^{14}$

As the great handicap of Sibley's force was the lack of mounted men with which to pursue the Indians, Governor Ramsey telegraphed to the Secretary of War for five hundred horses, and upon his refusal to supply them at once, he appealed directly to President Lincoln. "This is not our war," he said;

11 Sibley to Ramsey, Aug. 20, 1862, in Minnesofa in the Civil and Indian Wars, 2:165.

${ }^{12}$ On August 22, 1862, Governor Ramsey issued a proclamation calling upon the people not to be unduly alarmed and flee from their homes in regions where there was no immediate danger. Records, Executive Office $1858-1862$, pp. $634-636$, in archives of Governor's office.

${ }^{13}$ Sibley to Ramsey, letter published in Pioneer and Democrat, Aug. 26, 1862. Sept. 7,1862 . 
"It is a national war. I hope you will direct the purchase or send us five hundred horses, or order the Minnesota companies of horse in Kentucky and Tennessee home. Answer me at once. More than 500 whites have been murdered by the Indians." 15

Although unable to supply the mounted force at once, the authorities at Washington realized the seriousness of the situation and created the military department of the Northwest and sent Major-General John Pope, who had recently been relieved of his command of the army of the Potomac, to take charge with headquarters in St. Paul. He was directed to "take such prompt and vigorous measures as shall quell the hostilities and afford peace, security, and protection to the people against Indian hostilities." 16

It has already been pointed out that the lack of men, equipment, and provisions caused Sibley's expedition to move more slowly than it otherwise would have done. The people of the State did not understand the reason for the delay and many well-meaning people unmercifully criticised Sibley for not taking immediate action against the Indians. The republican press, and especially the Minnesotian, was particularly bitter against him. ${ }^{17}$ While Sibley would have moved faster if it had been possible, yet hehad another object in mind which demanded cautious action on his part. The Indians had captured some three hundred prisoners, mostly women and children, and Sibley feared that hasty action on his part would cause the Indians to massacre all the prisoners. With a view of obtaining some knowledge of the number and the condition of the prisoners by inducing Little Crow to send a half-breed for a conference,

${ }^{15}$ Ramsey to Lincoln, Sept. 6, 1862, in Minnesota in the Civil and Indian Wars, $2: 225$.

${ }^{10}$ Stanton to Pope, Sept. 6, 1862, in Minnesota in the Civil and Indian Wars, $2: 226$.

${ }_{17}$ The Missionary Riggs expressed the situation clearly in a letter to Ramsey: "I became pretty well acquainted with the feeling that then existed in regard to this expedition-that the movements were too slow and cautious. I confess that I sympathized somewhat in this feeling. :. In looking at the past and the present $I$ am satisfied that Colonel Sibley has acted wisely in not advancing until he is well prepared for offence and defence. The safety of his command requires it. He is anxious to go forward at the earliest practicable moment. At the same time this necessary delay for ammunition is likely to work good in regard to the prisoners. If so, we shall none of us regret it." Minnesota in the Civil and Indian Wars, 2:226-7. 
Sibley left the following note on a stake on the battlefield of Birch Coolie:

"If Little Crow has any proposition to make to me let him send a halfbreed to me, and he shall be protected in and out of my camp."

The half-breed came with the following letter from Little Crow:

\section{"Dr. Sir,}

for what reason we have commenced this war I will tell you. it is on account of Maj. Galbraith, we made a treaty with the Government a beg for what lettle we do get and then cant get it till our children was dieing with hunger-it was with the traders that commence Mr A. J. Myrick told the Indians that they would eat grass or their own dung. Then Mr Forbes told the lower Sioux that were not men then Robert he was making with his friends how to defraud us of our money. If the young braves have push the white man I have done this myself. So I want you to let the governor Ramsey know this. I have great many prisoners women and children it aint all our fault the Winnebagoes was in the engagement, two of them was killed. I want you to give answer by bearer all at present.

\section{Yours truly his \\ Friend Little x Crow."1s mark}

On September 12, Little Crow sent word to Sibley that he had one hundred prisoners who were well cared for, and asked how he could make peace. Sibley demanded the return of the prisoners before he would consider any proposition of peace. At the same time two friendly Chiefs, Wabasha and Taopi, sent a secret communication to Sibley offering to turn over the prisoners if arrangements could be made. Sibley told them that if they would get the prisoners and all friendly Indians who were in Little Crow's camp out on the open prairie in day time and come to his camp under a flag of truce, they would be received by him. From this time until the prisoners were finally surrendered, two weeks later, Sibley was hoping for the friendly Indians to get an opportunity to get away from Little Crow. ${ }^{19}$

\footnotetext{
18 Published in the Pioneer and Democrat, Sept. 11, 1862.
${ }^{10}$ Pioneer and Democrat, Sept. 16, 1862.
} 
In the meantime, the most serious battle of the campaign took place. Sibley left Fort Ridgley on September 19 and reached Wood Lake, near the Yellow Medicine river, on September 22. On the following day he was attacked by some three hundred warriors, but, after two hours of hard fighting, he succeeded in defeating them. One reason that more warriors did not take part in the battle was because the group of "friendly" Indians who, as Sibley wrote, had opposed the war "but were driven into the field by the more violent," were looking for an opportunity to turn the prisoners over to Sibley. ${ }^{20}$ After the battle of Wood Lake, Little Crow and his followers fled, and the "friendly" Indians then had their opportunity to surrender and turn the prisoners over to Sibley. The account of this surrender is best told in Sibley's own words: "I entered, with my officers, to the center of the circle formed by the numerous lodges, and seeing the old savage whom I knew personally as the individual with stentorian lungs, who promulgated the orders of the chiefs and head men to the multitude, I beckoned him to me, and, in a peremptory tone, ordered him to go through the camp and notify the tenants that I demanded all the female captives to be brought to me instanter. And now was presented a scene which no one who witnessed it can ever forget. From the lodges there issued more than one hundred comely young girls and women, most of whom were so scantily clad as scarcely to conceal their nakedness. On the persons of some hung but a single garment, while pitying halfbreeds and Indian women had provided others with scraps of clothing from their own little wardrobes, answering, indeed, a mere temporary purpose. But a worst accoutered, or more distressed, group of civilized beings imagination would fail to picture. Some seemed stolid, as if their minds had been strained to madness and reaction had brought vacant gloom, indifference, and despair. They gazed with a sad stare. Others

20 Sibley to Ramsey, Sept. 23, 1862, published in St. Peal Pioneer, Sept. 27, 1862. (The name of this paper was changed from Pioner and Democrat back to the original name Pioner on September 25, 1862.) 
acted differently. The great body of the poor creatures rushed madly to the spot where I was standing with my brave officers, pressing as close as possible, grasping our hands and clinging to our limbs, as if fearful that the red devils might yet reclaim their victims. I did all I could to reassure them, by telling them they were now to be released from their sufferings and freed from their bondage. Many were hysterical, bordering on convulsions, laughter and tears commingling, incredulous that they were in the hands of their preservers. A few of the more attractive had been offered the alternative of becoming the temporary wives of select warriors, and so, helpless and powerless, yet escaped the promiscuous attentions of a horde of savages bent on brutal insult revolting to conceive, and impossible to describe. The majority of these outraged girls and young women were of a superior class, some were school teachers, who, accompanied by their girl pupils, had gone to pass their summer vacation with relatives or friends in the border counties of the State. The settlers, both native and foreign, were, for the most part, respectable, prosperous, and educated citizens whose wives and daughters had been afforded the privileges of a good common school education. Such were the delicate young girls and women who had been subjected for weeks to the inhuman embraces of hundreds of filthy savages utterly devoid of all compassion for the sufferers. Escorting the captives to the outside of the camp, they were placed under the protection of the troops and taken to our own encampment, where I had ordered tents to be pitched for their accommodation. Officers and men, affected even to tears by the scene, denuded themselves of their entire underclothing, blankets, coats, and whatever they could give, or could be converted into raiment for these heartbroken and abused victims of savage lust and rage. The only white man found alive when we reached the Indian encampment was George H. Spencer, who was saved from death by the heroic devotion of his Indian comrade, but was badly wounded. He said to me: 'It is God's mercy, that you did not march here on the night after the battle. 
A plan was formed, had you done so, to murder the captives, then scatter to the prairies'-thus verifying my prediction of the course they would pursue. I bless God for the wisdom he gave me, and whereby, with the aid of my brave men, in spite of all slander and abuse, I was enabled to win a victory so decisive, and redeem from their thraldom those unfortunate sufferers who were a burden on my heart from the first moment of the campaign." 21

Along with the friendly Indians, some of those who had taken part in the massacres came to Sibley's camp. Of those who surrendered, Sibley reported to General Pope that sixteen were thus suspected. "If found guilty," he wrote, "they will be immediately executed, although I am somewhat in doubt whether my authority extends quite so far. An example is, however, imperatively necessary, and I trust that you will approve the act, should it happen that some of the real criminals have been seized and promptly disposed of."

On September 27, 1862, Sibley asked to be relieved of his command. In a letter to General Pope he stated that two of the objects of the expedition had been accomplished, the checking and beating of the Indians and relieving the settlements, and the delivery of the prisoners held by the Indians. $\mathrm{He}$ stated his belief that "a strictly military commander" would be better fitted for the task of following up and exterminating the Indians than himself and said that his private affairs demanded his personal attention. ${ }^{23}$ Instead of Sibley being relieved, however, he was made a Brigadier General in the United States army and left in immediate charge of the expedition. ${ }^{24}$

General Pope shared Sibley's determination to exterminate the Sioux and remove once for all this menace to the frontier

${ }^{21}$ Sibley's Notes on the Indian War, published in West, Sibley, 276,

"n Sibley to Pope, Sept. 27, 1862, published in St. Pesul Pionem, Oct. 3, 1862 2:2 4-255.

, published in Minnesota in the Civil and Indian Wers,

"Halleck to Pope, Sept. 29, 1862 , in Minnesota in the Civil and Indian Warz, 2:258. While

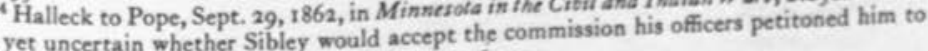
do so. Minnesola in the Civil and Indian Wars, 2:269-270. 
of Minnesota. "No treaty must be made with the Sioux, even should the campaign against them be delayed until summer," he wrote. "If they desire a council, let them come in, but seize Little Crow and all others engaged in the late outrages, and hold them prisoners until further orders from these headquarters. It is idle and wicked, in view of the atrocious murders these Indians have committed, in face of treaties and without provocation, to make treaties or talk about keeping faith with them. The horrible massacres of women and children and the outrageous abuse of female prisoners, still alive, call for punishment beyond human power to inflict. There will be no peace in this region by virtue of treaties and Indian faith. It is my purpose utterly to exterminate the Sioux if I have the power to do so and even if it requires a campaign lasting the whole of next year. Destroy everything belonging to them and force them out to the plains, unless, as I suggest, you can capture them. They are to be treated as maniacs or wild beasts and by no means as people with whom treaties or compromises can be made. Urge the campaign vigorously; you shall be vigorously supported and supplied." 25

Sibley was handicapped still by the lack of provisions and a sufficient mounted force. On September 28 he wrote to Flandrau: "I am, as usual, out of rations, many of my companies having no flour and bread. If I had been furnished with 300 or 400 cavalry, I could have destroyed two-thirds of the hostile Indians after the battle of the 23 rd." ${ }_{26}$ Two days later he he wrote to Pope: "The camp would be in a starving state but for the potatoes found in the Indian fields." 27

Early in October other bands of Sioux began to come in and surrender to Sibley. On October 7 , Sibley wrote to Pope that thirty-seven lodges had surrendered, twenty other lodges were within ten or twelve miles of his camp, and that fifty 2:257.

Ibid, 2:258.

${ }^{27} \mathrm{Ibid}, 2: 260$. 
more were expected within two or three days. Meanwhile Sibley had created a court marital of army officers and was proceeding to search out those Indians who had participated in the massacres. "I have not yet examined the proceedings of the military commission," he wrote to Pope, "but although they may not be exactly in form in all details I shall probably approve them, and hang the villains as soon as I get hold of the others. It would not do to precipitate matters now, for fear of alarming those who are coming forward to take their chances." 28

On October 10, Pope reported to Halleck that "the Sioux War is at an end." $\mathrm{He}$ added that it would be necessary to execute many of the Indians as this procedure would have a "crushing effect." $\mathrm{He}$ also issued an address requesting all frontier settlers to return to their homes. ${ }^{29} \mathrm{He}$ ordered Sibley to send all the Indian captives to Fort Snelling. This order caused Sibley to suspend the execution of those who had already been sentenced to death, about twenty in number, and to send them together with about fifteen hundred Indians to Fort Snelling. ${ }^{30}$

The attention of the authorities and the people of Minnesota now turned to the question of punishing the Indians who had been found guilty by the military commission. The settlers were almost unanimous in demanding the execution of the guilty culprits, and were not disposed to be too careful about absolute justice to individual Indians. When it became rumored about that President Lincoln intended to pardon many of the Indians, the people protested emphatically against such action. Almost alone among the people of the State,

${ }^{2}$ Minnesota in the Civil and Indian Wars, 2:267.

${ }^{20} \mathrm{Ibid}, 2: 272$.

20 "Your orders relative to the disposition of the Indians will be obeyed as promptly as possible. .... As the order is imperative to send all below, I shall suspend the execution of the sentenced Indians .... and dispatch them with the others." Minnesols in the Crit and Indian Wars, 2:273. There is a tradition in Minnesota that the condemned Indians were kept near Mankato until the time of their execution, but the author found no evidence that that was true. Neither was any order found revoking the above mentioned order to send all the indians to Fort Snelling. 
Bishop H. B. Whipple, of the Episcopal Church, raised his voice in behalf of the despised Indian. Whipple's ideas on the Indian policy of the United States Government were similar to those voiced by Sibley during his term in Congress. On December 3, 1862, he wrote an open letter to the editor of the Pioneer in which he pointed out that the white man was not entirely without blame for the unfortunate and distressing events of the preceding months. He indicated two serious mistakes on the part of the United States. "Our first dealing with them as a government," he wrote, "was based upon a falsehood. We purchased their lands as of an independent nation, forgetting they were only our heathen wards. . . The second most fatal error was a natural inference from the first. Because we had treated with them as an independent nation, we left them without a government." No steps were taken, he said, to restrain their savage warfare; no mark of condemnation had been placed upon their pagan customs. The annuity system had not encouraged honest labor, and the sale of "firewater had been unblushing when we knew that if it made drunkards of white men, it made red men devils." "The system of trade was ruinous to honest traders and pernicious to the Indian. It prevented all efforts for personal independence and acquisition of property. The debts of the shiftless and indolent were paid out of the sale of the patrimony of the tribe. If the Indian abandoned his wild life, built himself a house and cultivated the soil, he had no redress against the lawlessness of wild men. . . . Such a mistaken policy would be bad enough in the hands of the wisest and best men, but it is made an hundred fold worse by making the office of Indian Agent one simply of reward for political services." Bishop Whipple affirmed that justice demanded punishment for the guilty, but "while we execute justice," he added, "our consciousness of wrong should lead us to the strictest scrutiny, lest we punish the innocent. Punishment loses its lesson where it is the vengeance of a mob. The mistaken cry to take law into our own hands is the essence of rebellion itself." $\mathrm{He}$ also discussed the removal of the Sioux 
which was being demanded by Governor Ramsey and the people of the State. "Many of these Indians have been removed again and again," he wrote, "and each time been solemnly pledged that this would be forever their home. If a removal were to take place, we ought to see that our nation does its whole duty, that they should have a strong government, an individual right to the soil, a just system of trade, a wise system of civilization, and just agents. It is due alike to ourselves and to them that these systems shall no longer be foster-parents to mature savage violence and blood. Such a reform demands the calmest thought of the best men of the nation." ${ }_{31}$

In vain was this eloquent appeal for calmness on the part of the people of Minnesota and for justice for any Indians who were not found guilty of participating in the massacres. On December 6, Sibley reported to the commander of the department as follows: "About II o'clock on the night of the 4 th instant the guard around the Indian prisoners at Camp Lincoln were assaulted by nearly 200 men who attempted to reach the prisoners, with the avowed intention of murdering the condemned prisoners." Two days later he reported: "Combinations, embrasing thousands of men in all parts of the State, are said to be forming, and in a few days our troops, with the Indian prisoners, will be literally besieged. I shall concentrate all the men at Mankato. But should the President pardon the condemned Indians, there will be a determined effort to get them in possession, which will be resented, and may cause the lives of thousands of our citizens. Ask the President to keep secret his decision, whatever it may be, until I have prepared myself as best I can. God knows how much the excitement is increasing and extending. Telegraph without delay to headquarters." ${ }_{32}$ The situation called forth a proclamation from Governor Ramsey in which he asked the people not to show mob violence towards the Sioux prisoners. ${ }^{33}$

31 St. Paul Pioner, Dec. 3, 1862.

32 Minnesota in the Civil and Indian Wars, 2:290-292.

' ${ }^{2}$ Records, Executive Office, $1858-18.12$, pp. $636-63^{8}$, in archives in the Governor's office; also published in the Pioneer, Dec. $7,1862$. 
President Lincoln called for the records of the military commission and after careful consideration of the evidence decided that only thirty-eight out of the three hundred condemned Indians should be executed. This action called out additional protests from the people of the State and from Minnesota's delegation in Congress. The action of the people of Minnesota provoked unfavorable comment by the press outside of the State. The Pioneer of December 7, 1862, contained a clipping from the Fournal of Commerce with the heading "Minnesotians Ferocious": "The act of the President revoking the sentence of death against three hunred Indians in Minnesota for complicity in the recent murders in that State has aroused the indignation of the Minnesotians, and the newspapers generally urge upon the people to take the matter into their own hands and deal out vengeance upon all Indians in the State. The language of the newspapers is intemperate and defiant; it could not be more so if they were published in South Carolina. Is indiscriminate slaughter of Indians one of the reserved State rights of loyal Minnesota?" The Pioneer said that the people only demanded the execution of the sentence pronounced by the military commission, and not "vengeance upon all Indians in the State." The situation was well stated by the Pioneer of October 8, 1862: "The people have lost all confidence they ever possessed in 'friendly' Indians, and have not much left in those who style themselves 'Christian' Indians. If there are missionaries or traders who are willing to trust their lives in the hands of these 'Christian' or 'friends,' let them follow their protégés to the plains of the far west, and make what they can of them as proselytes and customers."

The date of the executions was originally set for December 19, I862, but, the time being too short to make the necessary preparations, it was extended until December $26,1862 .{ }^{34}$ On that day the thirty-eight condemned Indians were executed on one scaffold at Mankato at the signal of a roll of drums, in the presence of several hundred whites and some Indians. No dis-

\footnotetext{
"Lincoln to Sibley, Dec. 16, 1862, in Minnesofa in the Cioil and Indian Wars, 2:292.
} 
order occurred, the troops being drawn up in the form of a hollow square about the scaffold. ${ }^{35}$

Various estimates have been made regarding the loss of life and property occasioned by the Sioux outbreak. The loss in life, including the soldiers, was probably about five hundred. Most of the upper Minnesota valley was desolated and almost, if not quite, depopulated. ${ }^{36}$ In some counties provision had been made for the organization of county government before the outbreak, and such organization entirely disappeared. ${ }^{37}$ When the Sioux Commission was created to consider claims for damages arising from the outbreak, some 2,940 claims were filed, aggregating $\$ 2,500, \infty 0 .^{38}$ Appeals for the relief of the victims were sent out, and churches in Illinois, Indiana, Pennsylvania, New York, and New England sent aid of various kinds. Minnesota contributed $\$ 25,000$ to the relief fund. ${ }^{39}$ Part of the relief provided by Congress was for some of the "friendly" or "Christian" Indians. Contemporary opinion varied considerably as to the services rendered to the whites by these individuals who had given up their wild life and were trying to live according to civilized standards. There can be no question, however, but that many of the whites who survived the massacre owed their lives to these "Christian" Indians. It should be remembered that these Indians risked not only their property but even their lives in trying to save the whites. John Other Day was a notable example of this type of Indian. At the time of the outbreak he was living in a comfortable dwelling near the Minnesota river, had his land well fenced, and had a good crop of corn and potatoes. When he heard of the massacre he took instant action to save the whites. He assembled sixty-two men, women, and children, and conducted them some one hundred fifty miles to safety. Needless to say,

st Sibley to Lincoln, Dec. 27, 1862, in Minmesora in the Ciril and Indian Wars, 2:jo2. Also published in the Pioneer, Dec. $28,1862$.

${ }^{*}$ Minnesota History Bulletin, $1: 460$.

${ }^{27}$ Instances of this are revealed in the archives of the Governor's office. $42 \mathrm{t}$.

28 Bryant, and Murch, A History of the Great Messacre by the Sionx Indians in Minnesota,

${ }^{2}$ Ibid, 435 . 
all his property was destroyed by the Indians who were on the war path. Congress later appropriated $\$ 2,500$ to reimburse him for the loss, but this was generally regarded as inadequate to compensate him fully. ${ }^{40}$ No doubt there were many instances where the "friendly" Indians risked their all for the ideal that had been held before them by the missionaries. For want of historical evidence individual recognition cannot be given, and their story must remain largely an unwritten chapter in the history of the frontier. One of the saddest features of the whole affair was that when punishment was inflicted upon the Sioux it fell chiefly upon the innocent "farmer" Indians. The inconsistency of the United States Government in its dealings with the Indians was fully revealed in the punishment placed upon the Sioux "nation." The government made war upon the Sioux, took prisoners of war, and then tried and executed them for murder. Not only this, but those who were not convicted of participating in the massacres were punished by having their property confiscated, being removed from the State of Minnesota, and taken to a new reservation on the Missouri river. $^{41}$ It is the old story of the triumph of civilization over savagery, a triumph of necessity accompanied by injustice to the inferior race.

There still remained the task of pursuing and chastising the Sioux who had escaped to the western plains. For this purpose expeditions were organized in 1863 and 1864 . Little Crow himself deserted the bands on the Missouri, wandered back to the Minnesota valley during the summer of 1863 , and was shot near Hutchinson, Minnesota, on July 6, $1863 .{ }^{42}$ The plan of campaign for $186_{3}$ involved two expeditions, one under Sibley and the other under Sully. The former was to go up the Min-

40 Sibley, "Sketch of John Other Day," in Minnesota Historical Collections, 3:99-102.

"Paxson, The Last American Frontier, 239-240. Also Bryant and Murch, $A$ History of the Great Massacre by the Sioux Indians in Minnesota, 470-482. Also Minnesota History Bulletin, $2: 422$.

${ }^{62}$ A letter dated July 6, 1863 , and signed "J. W. M.," describing the killing of Little Crow was published in the St. Paul Daily Press, July 10, 1863. 
nesota river and drive the Sioux westward; the latter was to go up the Missouri river and head them off. It was hoped that this plan would cut the Minnesota Sioux off from communication with the Dakota Sioux and would make possible the crushing of the former between these two military forces. Sibley, with a force of about 3,000 , of whom 1,000 were cavalry, advanced up the Minnesota river and headed for the region of Devil's Lake. He drove the Indians before him, either across the Missouri or into the British possessions. Sully's expedition up the Missouri was delayed, however, and the campaign as a whole was not successful. The battle of Big Mound was fought by Sibley's force on July 24, and the battle of Stony Lake on July 28,1863 . The latter was the most important battle fought on the northwestern frontier. There were probably 2,500 Indian warriors engaged in the battle of Stony Lake, and their defeat no doubt had a good effect on the Indians of the Dakota region. The force was scattered but not destroyed, and this made necessary another campaign in 1864 . The latter campaign also failed to crush the Sioux completely. ${ }^{43}$ It was believed that the Indians received not only refuge in British territory, but actual assistance from British traders. In his report of the expedition of 1864 , Sibley regarded this situation as largely responsible for the continuance of hostilities on the part of the Indians. He stated that "the British Govern ment still permits her majesty's territories to be made a refug of the murdering bands who disturb the peace of our frontier, from the pursuit of the troops under my command, and these savages are in constant and open communication with British traders, who furnish them with ammunition and other articles with which to carry on the war with our government without lot or hindrance by the local authorities. Indeed, the halfbreed subjects of her Britannic Majesty traverse our own domain in every direction for purposes of trading and hunting, and are thus directly interested in the continuance of hostilities between us and the upper bands of Sioux Indians, and it is

"Bryant and Murch, $A$ History of the Great Massacre by the Sioux Indians in Minneseta, 491. Also Minnesota in the Civil and Indian Wars, 2:297-304; 3 to. 
known that they foment discontent with the Chippewas with whom they come in contact by representation that they are defrauded by the United States Government by payment in paper instead of coin, of the money due them under the treaty stipulations." ${ }_{44}$

Occasional raids into Minnesota occurred during 1863 and I864 and caused very much dissatisfaction on the part of many settlers of Sibley's management of the frontier situation. The raiding bands were small and succeeded in slipping through Sibley's lines and committing occasional murders in isolated settlements. Some of the newspapers of the State criticised Sibley's disposition of troops along the frontier. Under date of May 13, 1863, an unsigned letter was sent to Sibley calling upon him to resign his command and let someone have it who could give adequate protection. ${ }^{45}$ The settlers were unreasonable in that they expected Sibley with the small force under his command to guard adequately every frontier settlement at all times. Governor Miller, of Minnesota, recognized that Sibley's force was "not sufficient to protect the six or seven hundred miles of frontier which is exposed to savage raids," and asked Secretary of War Stanton to increase the number of men in Sibley's command.

With the closing of the Civil War in 1865 the Indian hostilities were gradually brought to a close. Sibley closed his military career in 1865 and retired to private life. With the passing of time the people of Minnesota generally recognized both the difficulties under which Sibley worked and the ability with which he solved the problems which confronted him in overcoming the last desperate stand of the Sioux for the possession of the soil of Minnesota.

Ibid, 2:525-526.

is "The enclosures are sent you to show you the feeling of the press. They show but faintly the indignation of an outraged people who charge upon you the blood of hundreds of poor murdered victims. If you will not punish the Indians why for God's sake dont you resign \& let some one have your place who will save this country from desolation from the savages. Will you not do something to atone for causing by your neglect so many murders? The circulars are from two Republican \& two Democratic papers. Read and profit by it." This letter is found among the Sibley Papers. The clippings are also found with the letter and were from the Mankato Union, the Winnebago City Homestead, the Faribault Central Republican, and the LeSueur Statesman. The St. Paul Pioneer, as usual, defended Sibley against these attacks. 


\section{CHAPTER XI}

\section{PIONEER DREAMS COME TRUE}

Although the most important part of Sibley's career closed with his retirement from the army, yet many years of usefulness remained to him, and he was active and public spirited practically until the time of his death. As a sequel to his military career, he was a member of the Commission which negotiated the treaties of peace with the Sioux in 1865 and 1866 at Council Bluffs and Sioux City. ${ }^{1}$ Most of the remaining years of his life were given to private business. He was president of the St. Paul Gas Light Company, president of the Minnesota Mutual Life Insurance Company, of St. Paul, which later consolidated with the Northwestern Mutual Life Insurance Company, of Milwaukee, and also, for a time, president of the St. Paul City Bank. His private business, however, did not prevent his rendering service to the community in which he lived. He was president of the Chamber of Commerce, of St. Paul, for many years, retiring at his own request, in 1880 , and with the regrets of members of the organization. The most important public services which he rendered to the State, after 1865 , were as a representative in the State legislature, for one term, and as a regent of the University of Minnesota, a position which he held by appointment from successive Governors, all of whom were Republicans. ${ }^{2}$ He was President of the Board of Regents from 1876 until the close of his active career. In 1876 he tendered his resignation, but, at the earnest request of the Governor, J. S. Pillsbury, and the President of

\footnotetext{
(Misc.).

${ }^{1}$ Documents relating to this subject are published in West, Sibley, 338-342.

an the Sibley Papers

${ }^{2} \mathrm{His}$ commissions as Regent of the University of Minnesota are in the Sibley Papere
} 
the University, W. W. Folwell, he consented to continue his services. ${ }^{3}$

Sibley's term in the State legislature was in 1871 , at a time when strenuous efforts were being made to bring about a settlement of the State Railroad question. For some years after the adoption of the amendment prohibiting any action looking towards a settlement without a referendum to the electors of the State, nothing was done. In 1867 , a plan was suggested which seemed to open a way for the payment of the bonds. It was discovered that an act of Congress, in $184 \mathrm{I}$, had provided for a grant of 500,000 acres of land to certain States for internal improvements and that Minnesota was entitled to such a grant. Governor Marshall recommended that the proceeds from the sale of these lands be used for the settlement of the railroad indebtedness. Sibley, through the columns of the Pioneer, argued in favor of the plan and appealed to the people to seize this opportunity to clear the reputation of the State from the charge of repudiation. ${ }^{4}$ This proposition was rejected at the time, and in 1870 Sibley accepted a seat in the lower house of the legislature for the purpose of trying to influence that body to take favorable action on the question. On February 4, 1871, he introduced a resolution in favor of a just and fair settlement with bond-holders, and four days later he delivered a speech in which he admitted that he was advocating the unpopular side of the question and also that one of his objects in coming to the legislature was, as he said, "to vindicate myself and the administration of which I was chief from the numerous and baseless charges which have been made from time to time through a long series of years, of fraud, or to say the least, of irregularity in placing these State obligations in the possession of railroad companies, as required by 3 "General: On receiving your letter on Saturday I went at once to Governor Pillsbury and
begged him on behalf of the faculty not to accept your resignation. Your retirement from the board at this time would be a great calamity to the institution. No new man, however great his natural abilities, can perform the services which your long experience and acquaintance with the affairs of the University enable you easily to render. Your place cannot be filled. . ." Folwell to Sibley, May 21, 1876.

St. Paul Pioneer, May 1, 1867. 
the amendment to the fundamental law." He recited briefly the history of the whole question, including his stand in favor of prior lien bonds until the mandamus was issued by the Supreme Court. "This is the only phase in the history of the case," he said, "which has left behind it a feeling on my part of dissatisfaction. I then doubted, and the doubt has since increased until it has become almost a certainty, whether the action of the Supreme Court was not an infringement upon the rights and responsibilities of a co-ordinate branch of the State Government." Sibley stated that the Attorney General at the time informed him that he was estopped from denying the authority of the Supreme Court after having instructed the Attorney General to appear in behalf of the State. He also said that he did everything in his power as governor to guard the security of the State, and that "in no instance were State bonds issued to the respective companies until they had complied with every prescribed condition." He stated it as his belief that the bonds would have been placed with responsible banking firms in New York and that the plan for the construction of the roads might have been successful except for the violence with which the Republican press of the State attacked them. ${ }^{5}$ He also stated that the affairs of the railroad companies were better managed than had generally been believed. $\mathrm{He}$ closed his speech with an appeal to the people of the State to be honest in meeting their legal obligations.

At the preceeding session of the legislature, an act was passed authorizing the use of the 500,000 acres of land, as Governor Marshall had recommended in 1867 , but, upon its

"In speaking of his trip East to help place the bonds Sibley said: "I remained there two months at my own cost. I had nearly completed an arrangement with a leading banking firm ... when all my efforts... were rendered abortive by a furious editorial in the Minnesotian, which was sent to the firm ... denouncing in the most violent terms, the bonds and everyone connected with them." The Republican papers warned the capitalists that if they purchased the bonds "it would be at their own peril for repudiation was sure to follow."

" "They (the companies) have, in my judgment, been most unjustly denounced as swindling corporations. ... They never received a State bond which they had not fairly earned and if they failed in their engagements, it was owing to the fact that the bonds upon which they depended mainly to secure means to prosecute their work, were turned to ashes in their grasp, and rendered valueless by the unholy war waged upon them by our own citizens." 
being referred to the electors as provided in the constitutional amendment, it was rejected. The legislature in 1871 passed an act again submitting a plan of settlement, but it also was rejected. In 1876 , Governor Cushman K. Davis, in his last message to the legislature, urged that some settlement be made, with the bond-holder. "Let us meet our responsibilities," he said, "as becomes a great state holding her honor dearer than anything else. There is a higher rule of action which requires that states, no less than men, shall do justice, no matter how onerous the responsibility and the performance." 7 Governor Davis was succeeded by Governor J. S. Pillsbury, and the latter made it a chief object of his administration to secure a settlement of this question. Again and again he urged that Minnesota make some plan of settlement and clear her good name from the disgrace of repudiation. Finally, in 1880 , the bond-holders, chief of whom was Selah Chamberlain, offered to settle with the State at fifty cents on the dollar. Governor Pillsbury, on January 6, 1881, again appealed to the legislature to take action. "I implore the people of Minnesota," he said, "and you, gentlemen, their representatives, to seize this last opportunity, before it is too late, to wipe out this only blot from the fair name of our beloved state." 8 As it seemed impossible to get any settlement under the repudiating amendment to the constitution, the legislature passed an act for the creation of a special tribunal to pass upon the question as to the binding power of the repudiating amendment. After some difficulty in getting judges to serve on this tribunal, and after its competency had been challenged, the Supreme Court finally decided that the repudiating amendment was against the spirit of the provision of the United States Constitution prohibiting a state from impairing the obligation of a contract. The legislature then passed an act authorizing the issue of a special series of bonds known as "Minnesota state railroad adjustment bonds," and a bill for the use of the proceeds of the 500,000 acres of internal

'Executive Documents, State of Minnesota, $1878,41-42$.
Ibid, 1881 , 39. 
improvement land. The latter act was referred to the electors, and received a vote of 31 ,OII for, and 13,589 against, in an election where the total vote cast was 150,484 . On this basis, the State then accepted the offer of settlement at fifty cents on the dollar, together with the accrued interest, and at last the dream of the leading men to see Minnesota's reputation cleared from the stain of repudiation was a reality. ${ }^{9}$ An unbiased study of the whole question leads to the conclusion that Sibley's motives were honorable throughout, and that it was unjust to his administration to place so much blame for the five million loan episode as was done at the time by the press hostile to his administration. When he gave in to the mandamus proceedings he committed the only act for which he can be blamed, but even then he was doing what the people of the State probably wanted done. It is the old story that there must be a scape-goat for every great undertaking which does not succeed, and it fell to Sibley to play the part of the scape-goat. Although the State was strongly republican after 1860, and Sibley was a Democrat, and it is impossible to state what Sibley's career might have been without this episode, still it seems reasonable to conclude that the railroad bond question injured Sibley's standing in the political life of the State.

Railroad construction went forward by leaps and bounds in the decade following the Civil War, and when the people began to feel that railroads were a reality they found that unjust discriminations and exorbitant freight rates deprived them of many of the advantages which they had hoped to secure by having an outlet for their surplus products. As a result, the Granger movement received considerable support from the farmers of Minnesota. ${ }^{10}$ In spite of the difficulties over the adjustment of railroad rates, however, and even in spite of the effects of the Panic of 1873 , the two decades following the Civil War witnessed a marvelous growth of Minne-

The last bonds which were exchanged for the Railroad Bonds were paid in 1910 and th question was then finally settled.

ic See Buck, Granger Mocement, in Harvard Historical Series. 
sota. The population which in 1860 had been only 172,023 increased to 439,706 in 1870 , to 780,773 in 1880 , and by 1890 , about the time of Sibley's death, was I,501,826. The development of agriculture and mining was as remarkable as the growth in population. The labors of the pioneers to carve out of the wilderness a great State had been rewarded with success, and the pioneer dreams had come true.

The last years of Sibley's life were peaceful and happy. The period of "storm and stress" was over, and the bitterness of the rivalries of pioneer days was gone. The people of the State generally recognized the greatness of his work, and he was regarded as "the first citizen of Minnesota." One of the most pleasant social events of his later years was the banquet given in his honor, on November 7, 1884, celebrating the semi-centennial anniversary of his advent into the upper Mississippi country. Among the guests were the most distinguished men and women of Minnesota. A brief address was made by Ex. Governor C. K. Davis, and Sibley replied to it, closing his remarks with the following words: "My public and private record has been made up, and faulty and imperfect as it may be, it is now too late to alter or amend it. I thank God that he has spared me to see the fiftieth anniversary of my advent to what is now Minnesota, and to witness the transformation of this region from a howling wilderness, tenanted alone by wild beasts and savage men, into a proud and powerful commonwealth; and I especially thank Him for surrounding me in the evening of my days with troops of loving friends of both sexes, who overlook my many imperfections in their desire to smooth my pathway to the grave. It is a great consolation to me that I can leave my children the heritage of an honest name, and to my many friends a remembrance, not only of my devotion to them, but of my earnest and long-continued labors to advance the interests and welfare of our beloved Minnesota. . . ."11

Thus surrounded by admiring friends, Sibley spent the evening of his life by his fireside, living over again in his dreams

"Quoted in West, Sibley, 369-370. 
the many stirring scenes of his active career, and serenely contemplating the future. He was always a religious man. Brought up in a home which, while western, was typically New England in this respect, and living so near to nature as he had done, it could not well have been otherwise. Religious sentiments were frequent in his writings and public utterances, and, while even his last years were more or less active ones, he watched the approach of death with quiet resignation and perfect calm. He died on February I8, I89I, universally mourned by the people of the great State for which he had labored so long and in the making of which he had taken such a distinguished part.

\section{RETROSPECT}

The aim of this study has been not only to follow the life of Sibley, but also to attempt to portray, as he and other pioneers saw it, the gradual evolution of society and industry in the upper Mississippi country. The rapidity with which the West was settled is most vividly appreciated when viewed in terms of human life. In 1795 , when Solomon Sibley came over the mountains to the first American frontier settlement northwest of the Ohio river, the history of the great West, the real American West, was only in the period of beginnings. Before his son died, in 1891 , the frontier had disappeared. When Sibley, in 1834 , made his way into the region which became Minnesota it was a typical Indian frontier; when he died, Minnesota was a State with a population of almost one and one-half millions. As Sibley well said in his later life: "Our State has sprung into existence so recently that a few of us yet living have participated in or witnessed each step of her progress from pre-territorial times, when a few hundreds of men employed in the fur trade were all the whites to be found in the country, to the present time." 12 The settlement and development of the region had been so rapid that even those who had witnessed it could scarcely realize the transformation that had taken place before their very eyes. "It is scarcely

"Sibley, "Memoir of H. L. Dousman," in Minnessta Hisotrical Collections, 3:194. 
possible for such of my readers, as are not old settlers," Sibley wrote, "to appreciate the changes made within the last two decades in this Territory and State. Even as late as I 850 there were neither bridges nor ferries, and but few common roads other than foot trails of the red men who then asserted ownership of all the country west of the Mississippi except the military reservation at Fort Snelling. . . . In contrasting such a state of things with the present facilities for travel, exemption from danger, and the luxuries to be obtained in all the inhabited portions of the State, you may be enabled to form some faint conception of the amazement with which the transformation is regarded by the old settlers. To me, I must confess, it seems more like a pleasant dream than a reality." 13

The men who had made possible the great development and who had lived through all the stages of civilization from the fur traders' frontier were not without hope as to the future. While they fully appreciated what had already been done, they believed that Minnesota had greater days before her, and with confidence they trusted the coming generations to build upon the foundation which they had laid. No more fitting close can be made to this story of pioneer days than this spirit of hopefullness which found expression in Sibley's own words: "The retrospect, however satisfactory and indeed brilliant, in view of the rapid advance of the State in population and wealth, is not without its sad and melencholy aspects to such of the old settlers as yet remain. We miss from our companionship many a noble specimen of manhood who struggled and fought with us for the prosperity of our beloved Minnesota. They have gone the way of all the earth, and those of us who still live are daily admonished that our course also will soon be finished. It is a source of great comfort, as the shadows of death approach to encompass us, to be assured that the destinies of the commonwealth we have loved so long and so well will be left in the hands of a generation competent and deter-

\footnotetext{
"Sibley, "Reminiscences of the Early Days of Minnesota," in Minnesota Historical
Collections, $3: 276$.
} 
mined to control them, with the aid of a good providence, in the interests of morality and religion for the welfare of our children and of the great State and nation and reflectively of the whole human family." 14

u Sibley, "Reminiscences of the Early Days of Minnesota," in Minnesota Historical Collections, 3:276-77. 


\section{CHAPTER XII}

\section{BIBLIOGRAPHY}

I. Manuscript Material

Sibley Papers. This material consists of several thousands of papers preserved by Sibley, including his correspondence, from about $183^{\circ}$ and is particularly valuable for the history of the fur trade and for territorial politics. After Sibley retired from Congress in 1853 he remained in Minnesota, for the most part, and his correspondence is, therefore, not so extensive as while he was in Washington. About the same time he closed up his connection with the fur trade and the Papers cease to be valuable for that study. These Papers contain much valuable material for the history of the Northwest. Sibley carefully preserved his commissions of various kinds, maps, manuscripts of his writings, \&c., and these are to be found in this collection.

Legers, Journals, and Cash Books of the American Fur Company. These are to be found in the manuscript department of the library of the Minnesota Historical Society, along with the Sibley Papers, and are very valuable for the history of the fur trade in the upper Mississippi valley after Sibley's arrival at Mendota in 1834 .

Sibley's Order Book, 1862. This covers the operations against the Sioux during the campaign of 1862 .

Ramsey Papers. This collection of historical material is also in the possession of the Minnesota Historical Society. It contains many of Sibley's letters during the period $1849-1853$ and is particularly valuable for territorial politics.

Taliaferro Papers. These papers belonged to Major Taliaferro who was Indian Agent at Mendota from 1819 to 1840 . They throw light on the Indian relations and incidentally on the fur trade. Some of Sibley's letters are there. This collection is also in the library of the Minnesota Historical Society.

Archives in the Governor's Office, St. Paul, Minnesota. For a full description of these archives see Keller, Herbert A., "A Preliminary Survey of the More Important Archives of the Territory and State of Minnesota," in American Historical Association Report, 1914, 1 :389402.

II. Public Documents

The American State Papers, Indian Affairs. Volumes I and II, under titles such as "Indian Trade," "Factories," "Agents," \&c. furnish material on the general subject of Indians and the fur trade, some of which is valuable for this study. Volume II, pages $54-66$ contains Schoolcraft's "Report on the Fur Trade on the Missouri, 1815-1830." 
Annual Reports of Commissioner of Indian Affairs. This contains the reports made to the Commissioner by the Superintendents and Agents. They are found in the Reports of the Secretary of the Interior since I 849 . They are, of course, valuable for the study of Indian relations.

Congressional Globe. The 29th, 3oth, and 3 ist Congresses cover the period of Sibley's Congressional career as Delegate from Minnesota Territory and contain several of his speeches, together with the debates on the Minnesota Bill and other measures in which Sibley was interested.

Executive Documents, State of Minnesota. These were used for the period of Sibley's governorship and for the question of railroads in Minnesota.

Hodge, Frederick Webb, ed., Handbook of American Indians North of Mexico, 2 parts, Washington, Government Printing Office, 1910.

Valuable regarding the Indians of Minnesota.

Proceedings of the Constitutional Conventions, 1857.

Debates and Proceedings of the Minnesota Constitutional Convention.

Fournal of the Constitutional Convention of the Territory of Minnesota.

Each convention kept a record of its proceedings and these were published and are in the Library of the Minnesota Historical Society.

Royce, Charles C. (Compiler), Indian Land Cessions in the United States. 18th Annual Report of the Bureau of American Ethnology, $1896-97$, Washington, D. C. 1898 .

This gives an account of and maps showing all Indian land cessions. It is very valuable regarding treaties for cession of land.

Senate Documents, 32 Congress, 2 Session, Vol. III, Doc. No. 29. Indian Papers regarding Ramsey's official conduct in disbursing the money under the Treaties of 1851 are found here. It gives the evidence in the transactions as brought out by the investigation. Since Sibley was connected with the making of the treaties as a representative of the fur company interests it is valuable for this study.

Senate Documents, 1903-1904, Vol. 38. Kappler, Charles T., ed., Indian Affairs, Laws, Treaties. The title indicates its contents and value.

United States, Statutes at Large. Volume VII contains all the treaties with Indian tribes to March 3,1845 , since when they are given in the volume for the year when the treaty was made.

III. Newspapers

Pioneer. (Also under the title Pioneer and Democrat and after September, 1862, again under the title Pioneer.) Used for the period 1849 1865. This paper was Democratic in politics and was usually favorable to Sibley. It is valuable for the attitude of the Sibley faction in territorial politics as well as for the general news of the time. James M. Goodhue was its founder and editor until his death. Joseph R. Brown was at one time its editor.

Minnesota Chronicle and Register, 1849 -1851. These were two Whig papers, both started in 1849 , but consolidated in August, 1849 . In 1851 it was absorbed by the Democrat. These papers were favorable 
to Sibley while it was believed that he was a Whig, but were hostile to him when he announced himself as a Democrat.

509335 Shortridge Diss. 3379 on Io R.D.

Minnesota Democrat. This paper was founded in the interests of the Rice faction in the Democratic party. D. A. Robinson was the editor. It absorbed the Chronicle and Register in $185 \mathrm{I}$ and was finally consolidated with the Pioneer and published as the Pioneer and Democrat. It was, of course, hostile to Sibley before 1853 and is valuable as a means of seeing Sibley as his enemies saw him.

Minnesotian. This was a republican paper and was, therefore, hostile to Sibley, especially during the period of his governorship and during the campaign against the Sioux.

IV. General and Miscellaneous Material.

(Note: This consists of secondary material, magazine articles, pamphlets, articles in the Minnesota Historical Collections, \&c. Much of it is reminiscent in character and should be used with caution. Other parts are partly reminiscent and partly secondary, and other articles are purely secondary material. Articles or books of especial merit will be briefly described.)

Adams, Moses B., "The Sioux Outbreak in the Year 1862 with Notes of Missionary work Among the Sioux," in Minnesota Historical Collections, 9:431-52.

Ayers, Elizabeth T., "First Settlement on Red River of the North, I 8 I 2," in Minnesota Historical Collections, 6:421-28.

Baker, James Heaton, Lives of the Governors of Minnesota. St. Paul, 1908. This book was published as volume III of the Minnesota Historical Collections and contains a good brief account of Sibley.

Baker, James Heaton, "History of Transportation in Minnesota," in Minnesota Historical Collections, 6:1-34.

Benedict, William A., and Tracy, Hiram A., History of the Town of Sutton, Massachusetts, from 1704 to 1876 , Worcester, Massachusetts, 1878. This book gives information regarding the Sibley family in Sutton together with the ancestry of the individuals of the family who settled in Sutton.

Berghold, Alexander. The Indians' Revenge; or Days of Horror. San Francisco, 1891. An account of the Sioux War; not particularly valuable.

Bryant, Charles S., and Burch, Abel B., A History of the Great Massacre by the Sioux Indians in Minnesota. Cincinnati, 1864. This is a contemporary and useful account of the war. Bryant prosecuted claims for several clients before the Commission to examine claims for damages done by the Indians. He was, therefore, in a good position to hear the facts.

Bishop, Judson W., "History of the St. Paul and Sioux City Railroad, 1864-1881," in Minnesota Historical Collections, 10:399-41 5.

Blakely, Russel, "History of the Discovery of the Mississippi River and the Advent of Commerce in Minnesota," in Minnesota Historical 
Collections, 8:303-418. The author was a captain on a Mississippi river steamboat in the early days and that part of the article dealing with commerce has value. The other part is secondary material and not especially valuable.

Boutwell, W. T., "Schoolcraft's Exploring Tour of 1832, ," in Minnesota Historical Collections, $\mathrm{I}: \mathrm{I} 2 \mathrm{I}-\mathrm{I} 4 \mathrm{O}$.

Bromley, Edward A., "The Old Government Mills at the Falls of St. Anthony," in Minnesota Historical Collections, 10:635-643.

Buell, Salmon A., "Judge Flandrau in the Defense of New Ulm, during the Sioux Outbreak of $1862, "$ in Minnesota Historical Collections, I0: 783 .

Chief Big Eagle, "Story of the Sioux Outbreak in 1862," in Minnnesota Historical Collections, Vol. VI. This story as told by a participant was taken down by Return I. Holcombe in an interview with the Indian chief. It has value as giving the Indian side of the story but should be used with caution.

Chittenden, H. H., History of the Early Western Fur Trade, 3 Vols., New York, 1902. This is the best account of the fur trade as a whole but deals only slightly with the trade of the upper Mississippi.

Coman, Katherine, Economic Beginnings of the Far West, 2 Vols., New York, I912. This has a good chapter on the fur trade but does not give much on the fur trade in Minnesota.

Crooks, William, "The First Railroad in Minnesota," in Minnesota Historical Collections, 10:445-448.

Cutter, William Richard, ed., Genealogical and Family History of Eastern New York. New York, rgr2. Volume II contains a genealogical record of the Sibley family.

Daniels, Arthur M., A Fournal of Sibley's Indian Expedition during the Summer of 1863 and Record of the Troops Employed. Winona, Minn., 1864. This is a source of the expedition.

Daniels, Asa W., "Reminiscences of Little Crow," in Minnesota Historical Collections, Vol. 12.

Davis, Samuel M., "The Dual Origin of Minnesota," in Minnesota Historical Collections, 9:519-548.

DeCamp, (Mrs.) J. E., "Sioux Outbreak in 1862," in Minnesota Historical Collections, 6:354-380.

Durant, Edward W., "Lumbering and Steamboating on the St. Croix River," in Minnesota Historical Collections, 10:645-675.

Elfeld, Charles D., "Early Trade and Traders in St. Paul," in Minnesota Historical Collections, 9:163-168.

Elaison, Adolph O., "The Beginning of Banking in Minnesota," in Minnesota Historical Collections, 12:671-679. A good account of early banking operations.

Ellet, (Mrs.) Elizabeth Fries, Pioneer Women of the West. New York, 1852. This book contains a sketch of Sibley's mother. Sibley did not believe that the account was adequate and wrote to the author that, while it was true as far as it went, he could not help but think 
that his mother would smile at it, if she could come back from the other world and read the sketch.

Fairchild, Henry S., "Sketches of the Early History of Real Estate in St. Paul," in Minnesota Historical Collections, 10:417-443.

Flandrau, Charles E., "Progress of Minnesota during the Half Century, 1849-1899," in Minnesota Historical Collections, 9:587-596.

Flandrau, Charles E., "Reminiscences of Minnesota during the Territorial Period," in Minnesota Historical Collections, 9:197-222.

Folsom, William H. C., "History of Lumbering in the St. Croix Valley, with Biographical Sketches," in Minnesota Historical Collections, 9:291-324.

Folwell, William Watts, Minnesota the North Star State. Boston, 1908. Dr. Folwell, a former President of the Univeristy of Minnesota, is the best authority on the history of Minnesota.

Folwell, William Watts, "The Five Million Loan," in Minnesota Historical Collections, 15:189-214.

Folwell, William Watts, "The Sale of Fort Snelling, 1857," in Minnesota Historical Collections, 1 5:393-410.

Gilfillan, Charles D., "The Early Political History of Minnesota," in Minnesota Historical Collections, 9:167-180.

Gilfillan, John B., "History of the University of Minnesota," in Minnesota Historical Collections, 12:43-84.

Hall, H. P., Observations, being more or less a History of Political Contests in Minnesota, 1849-1904. St. Paul, 1905. This book was written "to warn young men not to abandon regular and legitimate business for the purpose of securing a foothold in political life. I frankly state that all the truth has not been told, and it is better for history, for the living and the memory of the respected dead, that there should be some omissions."

Hanson, Marcus L., Old Fort Snelling, I819-1858. Iowa City, Iowa, 1918. A very valuable account of an interesting subject.

Heard, Isaac V. D., History of the Sioux War and Massacre of 1862 and 1863. New York, 1863. The author was a member of Sibley's expedition and was recorder of the Military Commission which tried the Indians who were accused of participating in the massacres. He had, therefore, a good opportunity to get the facts, but his conclusions from the facts are not always correct.

Hildreth, S. P., Biographical and Historical Memoirs of the Early Pioneer Settlers of Ohio. Cincinnati, 1852. This contains sketches of the lives of some of the ancestors of Sibley on both his father's and mother's side, especially those who lived for a time at Marietta.

Hill, James J., "History of Agriculture in Minnesota," in Minnesota Historical Collections, 8:275-290. This is a good account of early conditions by a man whose interest in transportation would qualify him to speak with authority on economic conditions.

Holcombe, Return I., et. al., Minnesota in Three Centuries, 4 Vols. St. Paul, 1908. This is a co-operative work whose value depends upon 
the author of the particular volume in question. Volume II deals with the first part of the period covered in this biography and is not entirely reliable.

Hughes, Thomas, "Causes and Results of the Inkpaduta Massacre," in Minnesota Historical Collections, 12:263-282.

Hughes, Thomas, "The Treaty of Traverse des Sioux in 1851," in Minnesota Historical Collections, 10:101-129.

Johnson, Daniel S. B., "Minnesota Journalism in the Territorial Period," in Minnesota Historical Collections, 10:247-351.

Jordan, John W., ed., Genealogical and Personal History of the Allegheny Valley, Pennsylvania. New York, 1913. Volume I, pages 308-321, gives a genealogical account of the Sibley family which seems to have been based quite largely on the first chapter in West's Sibley.

Kiehle, David, "History of Education in Minnesota," in Minnesota Historical Collections, 10:353-398. A good account of the schools by a former State Superintendent of Public Instruction.

Kingsbury, David L., "Sully's Expedition against the Sioux," in Minnesota Historical Collections, 8:449-462.

Larpenteur, August L., "Recollections of the City and People of St. Paul, 1843-1898," in Minnesota Historical Collections, 9:363-394. Mr. Larpenteur was one of the pioneers and lived in St. Paul until Ig18. This is a good statement of facts by one who lived through all the stages of civilization from Indian frontier to the present time.

LeDuc, William G., Minnesota Year Book, 1851-53. This contains statistical information, together with important facts not easily accessible elsewhere on conditions in early Minnesota. The author was one of the "old settlers" who lived through all stages of civilization in the history of the West. He died in 1917.

MacDonald, Colvin F., The Nation's Response in 1862 to the Great Sioux Outbreak. The author took part in the expedition against the Sioux. He gives a rather complete account of the causes of the outbreak. In the Minneapolis fournal, February 18, 1912, the author has an article to disprove Confederate influence as a cause for the outbreak.

McClure, Nancy, "Captivity among the Sioux," in Minnesota Historical Collections, 6:438-460.

McCourt, Robert Shepard, The History of the Old Sibley House. St. Paul, 1910. This is the official souvenir of the Sibley House gotten out by the Daughters of the American Revolution. It is illustrated and gives many interesting facts regarding the old Sibley house at Mendota. It also contains a sketch of Sibley's life and also sketches of the lives of his mother and wife.

Mathews, Lois Kimball, The Expansion of New England. Boston, 1909. This is the best general account on the influence of the New England element in American History. It contains some reference to Solomon Sibley, the father of Henry Hastings Sibley.

Minnesota in the Civil and Indian Wars. 2 Vols. St. Paul, 1893. This work was gotten out by a board of commissioners appointed under an 
act of the legislature, April 22, 1892. Volume I is a secondary account of the part played by Minnesota's soldiers in the Civil War and in the expedition against the Sioux. Volume II contains the sources upon which I was based. It is a valuable work, especially volume II.

Moran, Thomas F., "How Minnesota Became a State," in Minnesota Historical Collections, 8:148-184.

Moss, Henry L., "Last Days of Wisconsin Territory and Early Days of Minnesota Territory," in Minnesota Historical Collections, 8:67-88. Mr. Moss was one of the early lawyers in Minnesota and was the first United States Attorney for Minnesota Territory. He was in a position to know the facts, but this account was written many years after the events happened and, as the author himself says, without refreshing his memory by reference to documentary material. It seems to have been in the nature of an impromptu speech. Many mistakes of fact occur in it and it cannot be safely used except where it is checked with and is supported by other historical material

Murray, William P., "Recollections of Early Territorial Days and Legislation," in Minnesota Historical Collections, 12:103-130.

Neill, Edward Duffield. History of the Minnesota Valley. Minneapolis, 1884 .

Neill, Edward Duffield, History of Minnesota. $\quad$ I882.

Neill, Edward Duffield, History of the Upper Mississippi Valley. $188 \mathrm{1}$. The author was, in his day, the best authority on the history of Minnesota. This work is valuable except where superceded by works based on later research.

Patchin, Sydney A., "The Development of Banking in Minnesota," in Minnesota History Bulletin, 2:1 I1 -168. This is the best account of the subject and was accepted as a thesis at the University of Minnesota.

Potter, Theodore N., "Recollections of Minnesota Experience," in Minnesota History Bulletin, I:419-521.

Randall, John H., "The Beginning of Railroad Building in Minnesota," in Minnesota Historical Collections, $15: 21$ 5-220.

Relf, Frances H., "Removal of the Sioux Indians from Minnesota," in Minnesota History Bulletin, 2:420-425. This is a letter, written by J. S. Wilkinson, the Missionary, who accompanied the Sioux when they were removed from Minnesota following the uprising of 1862 , together with editorial comment on it.

Renville, Gabriel, "A Sioux Narrative of the Outbreak in 1862 and of Sibley's Expedition in 1863," in Minnesota Historical Collections, 10:595-618. Renville was a half-breed and acted as scout for Sibley in 1863 . This account has value.

Robinson, Edward Van Dyke, Economic History of Agriculture in Minnesota. Bulletin of the University of Minnesota, 1915. This is a very valuable account of the economic development of an important industry and is the best thing in print on the subject. 
Rogers, George B., "History of Flour Manufacture in Minnesota," in Minnesota Historical Collections, I0:35-55.

Saby, Rasmus S., "Railroad Legislature in Minnesota, 1849-1857," in Minnesota Historical Collections, 15:1-188. This is the best account of the subject during this period.

Satterlee, Marion P., "Narratives of the Sioux War," in Minnesota Historical Collections, 15:349-370.

Schwandt, Mary, "Captivity among the Sioux," in Minnesota Historical Collections, $6: 46 \mathrm{I}-474$.

Sibley, Henry Hastings, "Description of Minnesota" (1850), in Historical Collections, $\mathrm{I}: 37-42$.

"History of the Minnesota State Railroad Bonds," Pamphlet No. I6 in volume on "Five Million Loan," in library of the Minnesota Historical Society.

"Memoir of Hercules L. Dausman," in Minnesota Historical Collections, 3:192-200.

"Memoir of Jean Baptiste Faribault," in Minnesola Historical Collections, 3:168-179.

"Memoir of Jean B. Nicollet," in Minnesota Historical Collections, $1: 18$ 3-195.

"Memorial Tribute to Rev. Gideon H. Pond," in Minnesota Historical Collections, 3:364-366.

"Reminiscences, Historical and Personal," in Minnesota Historical Collections, $1: 457-485$.

"Reminiscences of the Early Days in Minnesota," in Minnesota Historical Collections, 3:242-282.

"Sketch of John Other Day," in Minnesota Historical Collections, 9:99-102.

"Speech before the Committee on Elections of the United States House of Representatives, December 22, 1848 ," published in pamphlet form in Washington, 1849 . Also in Minnesota Historical Collections, I:69-75.

"Address to the People of Minnesota Territory," published in pamphlet form, Washington, 1850 . Also in West, Sibley, Appendix.

"Address of H. H. Sibley, of Minnesota Territory to His Constituents," published in pamphlet form in Washington. Also in West, Sibley.

"Inaugural Address, June 3, 1858," published in pamphlet form.

"Annual Message, 1859," published in pamphlet form. All of these pamphlets are in the library of the Minnesota Historical Society.

Simpson, Thomas, "The Early Government Land Surveys in Minnesota West of the Mississippi River," in Minnesota Historical Collections, I0:1 $57-167$.

Stevens, John H., Personal Recollections of Minnesota and Its People, and Early History of Minneapolis. Minneapolis, 1896. This is a valuable book by one of the "old settlers" and is particularly valuable in this study because the author, while a Whig, was a warm supporter of Sibley during the period of territorial politics. 
Stevens, Wayne E., "Organization of the British Fur Trade," in Mississippi Valley Historical Review, 3:172-202. This throws light on the fur trade in the upper Mississippi country before the advent of Sibley to Minnesota.

Sweet, George W., "Incidents of the Threatened Outbreak of Hole-inthe-Day and Other Ojibways, at the Time of the Sioux Massacre of 1862," in Minnesota Historical Collections, 6:401-408.

Texter, Lucy B., Official Relations between the United States and the Sioux Indians. Palo Alto, California, 1896 . This is an accurate and unbiased account of the subject.

West, Nathaniel, The Ancestry, Life, and Times of Henry Hastings Sibley. St. Paul, 1889. This book is good on the ancestry of Sibley and is valuable because the author had access to Sibley's manuscript autobiography, which seems to have been lost. Sibley read and approved the work. The chief objection to it is the style and the fact that it idealizes Sibley and makes him appear more as a demi-god than a human being.

Whipple, Benjamin. Lights and Shadows of a Long Episcopate. New York, 1902.

White, Mrs. N. D., "Captivity among the Sioux, August 18 to September 26, 1862," in Minnesota Historical Collections, 9:395-426.

Williams, J. Fletcher. A History of St. Paul and of Ramsey County. St. Paul, 1876 This work is published as a separate volume in the Minnesota Historical Collections. 


\section{INDEX}

American Board of Missions, 115.

American Fur Company, 8, 9, 12; issue in politics, 72,74 ; discredited, 78 .

Astor, John Jacob, 9, 12.

Bailly, Alexis, 15, 16, 31 .

Borup, Charles W., 26; discredits Sibley, 78 .

Boyce, John, 28.

Boyden, of North Carolina, opposes Minnesota Bill, 48.

Brown, Joseph R., 15, 16, 27, 38; and "traders' paper" of 1851 , I15; at Stillwater Convention, 40; supports Sibley, 65; supports Olmstead in 1850,75 .

Brown, Orlando, Commissioner of Indian Affairs, I0r, I07.

Buchanan, James, opinion regarding Wisconsin Territory, $4 \mathrm{I}$.

Burkleo, Samuel, at Stillwater Convention, $3^{8}$.

Cass, Lewis, 4,46 .

Catlin, John, 29, 40, 4I, 42, 43, 44, 46.

Chicago, description of in 1830,7 .

Chouteau \& Co., 24, 26.

Codification of laws for Minnesota, 80.

Compromise of 1850,47 .

Constitutional Convention for Minnesota, $127 \mathrm{et}$ seq.

Counties, organized in Minnesota, $69,123$.

Crooks, Ramsey, 9, 21; views as to Indian policy, 96 .

Dodge, Henry M., 42 .

Douglas, Stephan A., introduces Minnesota bill, 52 .

Dousman, H. L., 9 .
Dubuque's lead mines, 13 .

Election of 1850 in Minnesota, 76.

Falls of St. Anthony, 13 .

Faribault, Alexander, 15.

Faribault, Jean B., I5.

Five Million Dollar Loan, $132,135^{-}$ 138.

Free Soil Party, 47 .

Fort Snelling, 12.

Fox-Wisconsin route, $1_{3}$.

Fur Company, transformation into business establishment, 23.

Fur Trade, amount of in Minnesota, 25 ; barter, 21; British control, 12; prices of furs, 24 .

Fur Traders, II.

Fur Trading Posts in 1826,13 .

Gaspee, 6.

Gorman, W. A., appointed governor of Minnesota Territory, 121 .

Goodhue, James M., 63 .

Granger Movement, 169.

Great Britain's Indian Policy, 94.

Haskell, Joseph, 30 .

Holcombe, William, $3^{8,} 40$.

Hudson Bay Company, $3 \mathrm{r}$; use of liquor with Indians, $9^{2}$.

Indians, $11,2 \mathrm{I}$; contact of races, $9 \mathrm{I}$; decrease in numbers, 96; how they might be civilized, 98; policy of United States regarding, 92 ; "traders' paper" of $185 \mathrm{I}, \mathrm{I} 14$; treaties of $185 \mathrm{I}$, 109 et seq.

Indian Credits, $\mathbf{I} 4$.

Indian Trade, $19-20,23$; in connection with treaties, 1 ro.

Indian Traders, character of, 17 ; use of liquor, $9 \mathrm{I}$.

Indian Treaty of $1837,22,27$. 
Jones, George W., delegate from Michigan Territory, 42 .

Kittson, N. W., 15, 26.

Laframboise, Joseph, 15.

Lambert, David, 38 .

Land Claim Association, 32, 90.

Land Office, at St. Croix, Wisconsin, 43; moved to Stillwater, 59; established at Willow River, Wisconsin, 59 .

Lincoln, Abraham, vote on Minnesota bill, 51 .

Little Crow, 152.

Lumbering in Minnesota, 28, 29.

Marietta, Ohio, 5 .

Marshall, William R., nominated for delegate, 126.

Martin, Morgan L., introduces Minnesota bill, 35 .

Mendota, 9 .

Michigan Territory, 4.

Michigan, University of, 4.

Military Reserve at Fort Snelling, 88.

Minnesota Bill, introduced, 52; debated, 53-57; passed, 58; approved, 60.

Minnesota Territory, election of 1848,45 ; organized, 38 ; territorial appointments for, 60 ; admitted into Union, $13 \mathrm{I}$; effect of Panic of 1857 upon, 124; movement for statehood, 126 et seq; New England element in, 121; population of, 121-22.

Minnesota, population in $1860,124-$ 25; transformation from frontier to statehood, 171 .

Mitchell, A. M., and Rice Contract, 106, appointed Marshall for Minnesota, 60 ; candidate for delegate in 1850,71 .

Moss, H. L., appointed United States Attorney for Minnesota Territory, 60; at Stillwater Convention, 40 .
New England Element in Minnesota, I2I.

New England Town, method of forming, 3 .

New Hope (Mendota), 12.

Norris, James S., 30 ; views on Minnesota bill, 45 .

Northwest Fur Company, 16, 3I.

Ohio Company, 5 .

Ohio River Trade, 6.

Olmstead, David, 73.

Panic of 1857 , effect on Minnesota, 124 .

Parant, Peter, 32.

Penitentiary, located at Stillwater, 80.

Pembina, 15, 31, 33.

Polk, James K., memorial to, $3^{8}$; approves Minnesota bill, 60 .

Pond, Peter, I2.

Pope, General John, in command during Sioux War, 151 .

Post Roads in Minnesota, 81, 82.

Provencalle, Louis, 15 .

Puritan Emigration to Massachusetts, 2.

Railroads, agitation for in Minnesota, 84 ; beginning of construction, I39-140; Constitutional amendment for aid in building, 134, 138; construction of, 169 ; land grants asked for, 132-34; effect of Panic of 1857 upon, 134; Pacific Railroad advocated in 1850, 83; State Railroad Bonds, $167 \mathrm{et} \mathrm{seq.}$

Ramsey, Alexander, appointed governor of Minnesota Territory, 60; attitude towards State Railroad Bonds, 144 ; candidate for governor in 1857,129 ; investigation into conduct of regarding Sioux Treaties, 117; negotiation of Sioux Treaties, 112 et seq.

Red River Ox-carts, 33.

Regulators on Iowa Frontier, 102. 
Renville, Joseph, 15, 21, 30.

Republican Party, beginning of in Minnesota, 125.

Retail Trade, in connection with fur trade, $23,25,26$.

Retrospect, $171-73$.

Rice, Henry M., candidate for delegate in 1848,42 ; contract for removal of Winnebagoes, $100 \mathrm{et}$ seq.; faction in politics, 63 ; faction gains strength, 77 ; introduces Minnesota bill, 127; moved to St. Paul, 65; organized Democratic party in Minnesota, 66.

Riggs, S. R., in relation to 'traders' paper," 115.

Rolette, Joseph, Sr., 9, 13.

St. Anthony, 29.

"St. Clair" built at Marietta, 6 .

St. Croix County, Wisconsin, census of 1840,30 .

St. Paul, beginning of, 32 .

St. Peters River, 9 .

Selkirk, Lord, 3 I.

Sibley, Henry Hastings, of pure New England stock, 2; early life, 7; comes to Mendota, 12; in lumbering industry, 28; justice of the peace, 34 ; candidate for delegate in 1848,42 ; at Stillwater Convention, 38 ; elected delegate, 39 ; arrives in Washington, 47; admitted to seat in Congress, 50 ; faction in politics, 63 ; elected delegate in 1849,66 ; announces politics, 68 ; candidate for delegate in 1850,71 ; views on public land policy, 85 ; opposes bill for relief of indigent insane, 86; favors homestead bill, 86; views as to use of liquor in Indian trade, 92 ; views on Indian policy of government, 92-93; attempted to get enumeration of Indians, 96; explains how Indians might be civilized, 98 ; a squatter,
89 ; opposes Rice Contract, 103 et seg.; retires from Congress, 78 ; closed up connection with fur trade, 26; considered for territorial governor, 120; candidate for governor in 1857, 129; attitude towards Five Million Loan, 139; criticism of attitude towards Five Million Loan, 141 ; in Sioux War, 150 et seq.; close of military career, 164; in state legislature, 166; regent of University of Minnesota, 165; later life, 165 ; death, 171 .

Sibley House, 9.

Sibley, John, Mayor of St. Albans in England, 2.

Sibley, John, comes to Massachusetts, 2 .

Sibley, Jonathan, 3 .

Sibley, Joseph (I), 2 ; (II), 3 .

Sibley, Reuben, 3 .

Sibley, Solomon, 4 .

Sioux War of 1862 , causes of, 146 49; beginnings of hostilities, 149 ; expedition into Dakota, $162-64$; execution of Indians, $160-61$; women prisoners, $153-55$.

Slavery, condition of Indians compared with, 99 .

Sproat, Ebenezer, 5 .

Sproat, Sarah Whipple, 5.

Squatters, 27, 32; on military reserve, 88.

Steele, Franklin, 28, 29.

Stillwater Convention, 37, 38 .

Sutton, Massachusetts, 3 .

Swiss settlers from Pembina, 31 .

Taliaferro, Major, 13, 21.

Taylor, Joshua L., 38 .

Taylor, Zachary, makes appointments for Minnesota, 60 .

Telegraph line to Minnesota, 83 .

United States, Indian policy of, $9^{2}$, 93 . 
Woods, Major, expedition through Iowa, I849, I02-IO3.

Walker, Orange, 29.

Wallace, James, note regarding Gaspee, 6 .

Wheat, first shipped from Minnesota, 124 .

Whipple, Abraham, 5 .
Whipple, Bishop H. B., plea in behalf of Sioux Indians, 158-59. Wilcox, N. Green, candidate for delegate in 1850,73 .

Wilkinson, M. S., 38 .

Wilson, James, of New Hampshire, presents Sibley's credentials, 47 . Wisconsin, boundaries of, 36 . 